INEEL/EXT-2000-01167

October 2000

\title{
Idaho Nuclear Technology and Engineering Center Low-Activity Waste Process Technology Program FY-2000 Status Report
}
A. K. Herbst
J. A. McCray
R. J. Kirkham
J. Pao
M. D. Argyle
L. Lauerhass
C. L. Bendixsen
S. H. Hinckley 


\title{
IDAHO NUCLEAR TECHNOLOGY AND ENGINEERING CENTER LOW-ACTIVITY WASTE PROCESS \\ TECHNOLOGY PROGRAM FY-2000 STATUS REPORT
}

\author{
A. K. Herbst \\ J. A. McCray \\ R. J. Kirkham \\ J. Pao \\ M. D. Argyle \\ L. Lauerhass \\ C. L. Bendixsen \\ S. H. Hinckley
}

Published October 2000

\section{Idaho National Engineering and Environmental Laboratory Idaho Falls, Idaho 83415}

\author{
Prepared for the \\ U.S. Department of Energy \\ Assistant Secretary for Environmental Management \\ Under DOE Idaho Operations Office \\ Contract DE-AC07-99ID13727
}




\begin{abstract}
The Low-Activity Waste Process Technology Program anticipated that grouting will be used for disposal of low-level and transuranic wastes generated at the Idaho Nuclear Technology and Engineering Center (INTEC). During fiscal year 2000, grout formulations were studied for transuranic waste derived from INTEC liquid sodium-bearing waste and for projected newly generated low-level liquid waste. Additional studies were completed using silica gel and other absorbents to solidify sodium-bearing wastes. A feasibility study and conceptual design were completed for the construction of a grout pilot plant for simulated wastes and demonstration facility for actual wastes.
\end{abstract}




\section{SUMMARY}

The general purpose of the Low-Activity Waste Process Technology Program is to solidify and stabilize liquid transuranic and low-activity wastes (LAW) stored or generated at the Idaho Nuclear Technology and Engineering Center (formerly the Idaho Chemical Processing Plant). It is anticipated that LAW will be produced from the following: (1) chemical separation or ion exchange of the tank farm liquid sodium-bearing waste, (2) chemical separation of dissolved aluminum and zirconium calcines, and (3) newly generated liquid wastes, such as facility decontamination and process equipment wastes. Grout formulation studies included cesium ion exchanged sodium-bearing waste and newly generated liquid wastes. Additional studies were completed for absorbing sodium-bearing wastes, evaporation of newly generated liquid waste, and retention of mercury in grout.

Grout formulations were improved for the cesium separated sodiumbearing waste and the projected newly generated liquid waste. The sodiumbearing waste following cesium ion exchange separation waste would be a tranuranic waste that could be sent to the Waste Isolation Pilot Plant. The waste loading of 70 weight percent was maintained while improving the fluid properties of the grout mix. Grout formulations of up to 35 weight percent can be prepared for dilute newly generated liquid waste. Both of these formulations utilize the waste as the liquid for the cement powders.

Silica gel can be used to solidify sodium-bearing waste at up to 80 weight percent of the final dry product for a 33 percent volume reduction. The silica gel does not stabilize all hazardous metals, thus it is not a final waste form. The solid product can readily be vitrified due to the silica content and this final waste form will pass the Product Consistency Test (PCT). Alternatively, the solid product could be stored or transported later treatment.

A design study was completed to determine the feasibility of newly generated liquid waste being grouted and disposed to a permitted land disposal site, such as Envirocare of Utah. The project was expanded to include cesium separated sodium-bearing waste. A conceptual design for both processes was prepared and is pending final review. The design includes a grouting pilot plant for simulated wastes and a demonstration facility for actual radioactive wastes. 


\section{ACKNOWLEDGMENTS}

The authors express their gratitude to the following persons for their assistance in this program:

Dr. Steve Palethorpe, Process and Radwaste Chemistry, AEA Technology, Seascale, Cumbria, United Kingdom

Richard Simmons, Waste Management, AEA Technology, Dorchester, Dorset, United Kingdom

Dr. Bill Holtzscheiter, Tanks Focus Area, Westinghouse Savannah River Co., Aiken, South Carolina

John Harbour, Tanks Focus Area, Westinghouse Savannah River Co., Aiken, South Carolina

Betty Carteret, Tanks Focus Area, Battelle, Pacific Northwest National Laboratory, Richland, Washington

Robert Waters, Project Management, Bechtel, Idaho National Engineering and Environmental Laboratory, Idaho Falls, Idaho

Dana Meyers, Systems Design, Bechtel, Idaho National Engineering and Environmental Laboratory, Idaho Falls, Idaho

\section{POINTS OF CONTACT}

Of the authors, the areas of research were as follows:
Alan Herbst - Technical Lead and NGLW Grout Formulation
John McCray - CsIX Grout Formulation
Robert Kirkham - Silica Gel Suitability
Jenn-Hai Pao - Evaporation and Neutralization
Mark Argyle - Absorbent Tests
Lance Lauerhass - NGLW/CsIX Process Flowsheet Calculations
Lee Bendixson - NGLW/CsIX Grout Demonstration Project
Steve Hinckley - CsIX and NGLW Grout Formulation 


\section{NOMENCLATURE}

\author{
Alkaline Grout \\ Blast Furnace Slag
}

Calcination

Cement

CsIX

Denitration

Fly Ash

Grout

Leaching

Low-Activity Waste

NGLW

Portland Cement
A grout formulation where the waste is rendered basic $(\mathrm{pH}>12)$ and mixed with a 9:1 blend of blast furnace slag and portland cement.

A finely ground non-metallic waste produce developed in the manufacture of pig iron, consisting basically of a mixture of lime, silica, and alumina, the same oxides that make up portland cement, but not in the same proportions or forms.

The process of converting a liquid to a solid product called calcine.

Refers to type I/II portland cement.

A proposed process to treat sodium-bearing waste by cesium removal via ion exchange, then grouting and shipment to the Waste Isolation Pilot Plant.

Thermal process to destroy the nitrate content of the waste.

A pozzolan of finely divided residue that results from the combustion of ground or powdered coal. Class C fly ash may contain $10 \%$ lime, has cementitious properties, and reacts with water to form a solid. Class $\mathrm{F}$ fly ash does not use water and aids in grout flow.

A mixture of portland cement, other powdered additives, waste, and water. It may contain fine-grained sand and does not include large aggregate material. For this study, grouting is the process of solidifying and stabilizing low-level waste in cement based materials.

The process whereby a liquid agent will dissolve hazardous materials within a waste mass and transport these materials through the mass and beyond. The most widely used laboratory leaching test is the TCLP (Toxic Characteristic Leaching Procedure) specified by the EPA in several regulations. For many treated and untreated wastes, the results of this test determine whether the EPA considers the material toxic or not.

Low-level waste derived from the solvent extraction, ion exchange, and chemical extraction separation processes on the tank farm sodiumbearing waste and on the dissolved calcines.

Newly generated liquid waste -- low-level waste projected to be produced that is not part of the existing tank farm inventory. Sources are the process equipment waste system, decontamination solutions, and filter leach solutions.

The product obtained by pulverizing clinker consisting essentially of hydraulic calcium silicates. 
Pozzolan

Solidification

Stabilization

Water-to-Cement Ratio

Waste Form

Waste Loading

Vitrify
A siliceous or siliceous and aluminous material that reacts with liquid calcium hydroxide in the cement gel to form compounds possessing cementitious properties.

The process of producing from liquid, sludge, or loose solids a more or less monolithic structure having some integrity. Occasionally, solidification may refer to the process that results in a soil-like material rather than a monolithic structure. Solidification does not necessarily reduce leaching of hazardous materials. However, when a waste is solidified, its mass and structure are altered, decreasing migration of solutions within the mass.

Generally refers to a purposeful chemical reaction that has carried out to make waste constituents less leachable. This is accomplished by chemically immobilizing hazardous materials or reducing their solubility by a chemical reaction.

Defined as the mass of the water divided by the mass of the cements used (portland cement plus cement additives). In the case of the three way blends of portland cement, blast furnace slag, and fly ash, the mass of the water was divided by the total mass of the three cementing agents. The mass of the waste is not included in this calculation.

The final product for long-term storage. This includes the solidified/stabilized waste as well as the container. The waste form must pass extensive qualification testing prior to release for storage.

The mass weight percent of the waste in the total mass of the mixed grout.

The process of placing waste material in a glass form. This is a thermal process where the waste material is placed in a melter with glass beads or frit, then heated together, poured into a storage container, and cooled to a solid form. 


\section{CONTENTS}

1. INTRODUCTION …………………………………………………………....

2. Liquid Waste Treatment Demonstration................................................................................ 1

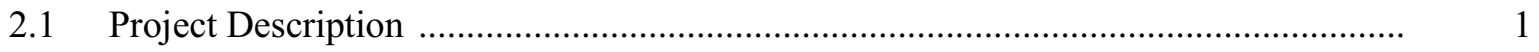

2.2 ASME Peer Review ………………………………………………………….....

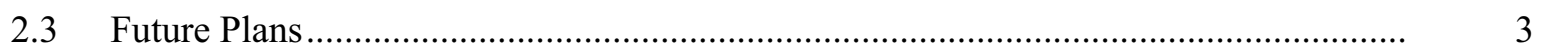

3. SBW CSIX GROUT DEVELOPMENT ………………………………………………......

3.1 Baseline CsIX Grout Formulation...................................................................................

3.2 CsIX Grout Formulation Optimization Testing ………………………………….....

3.3 Grout Viscosity Reduction Testing …………………………………………….....

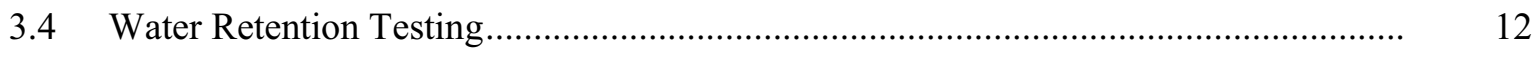

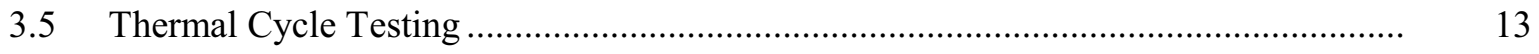

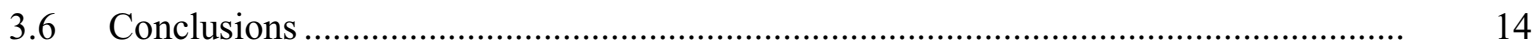

3.7 Recommendations and Discussion ........................................................................ 15

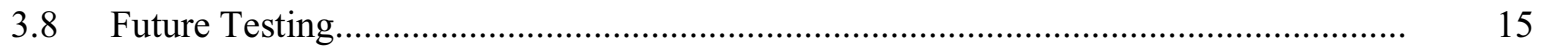

4. AUTOMATED GROUT MIXER TEST ………………………………………………... 16

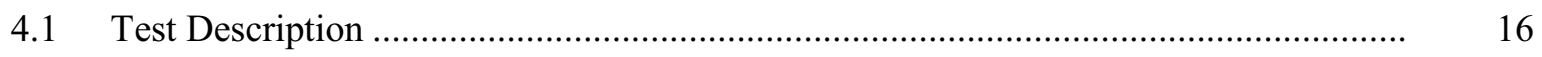

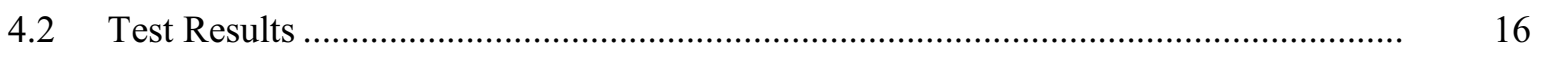

4.3 Overall Results and Concerns ……………………………………………………...... 18

5. NGLW Grout Development.......................................................................................... 23

$5.1 \quad$ Revised NGLW Grout Formulation …………………………………………….... 23

5.2 NGLW Evaporator and Base Reverse Addition Study .............................................. 24

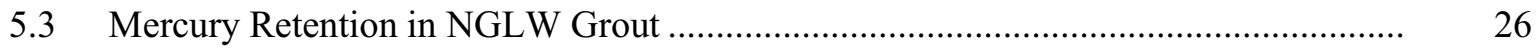

6. SILICA GEL PROCESS FOR SODIUM BEARING WASTE ................................................ 27

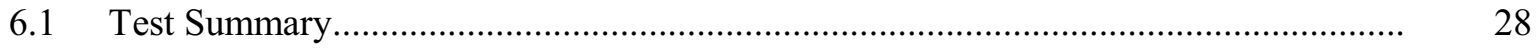




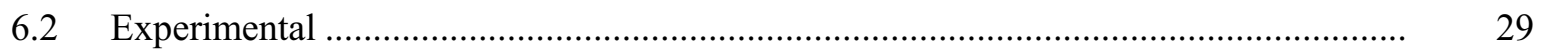

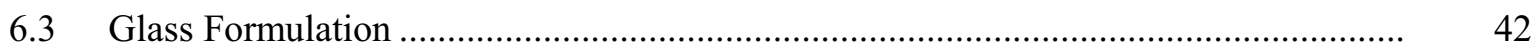

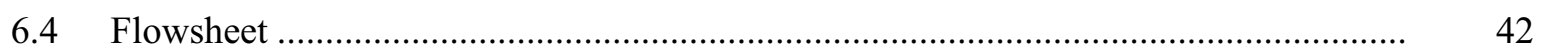

6.5 Conclusions and Recommendations....................................................................

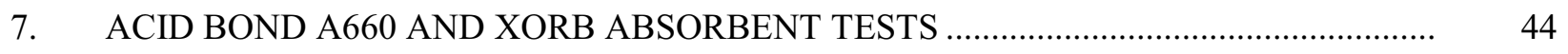

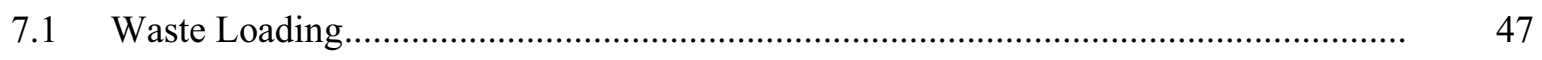

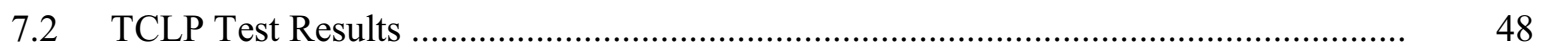

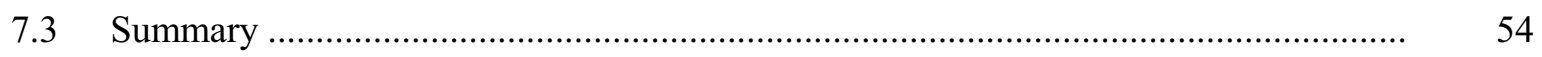

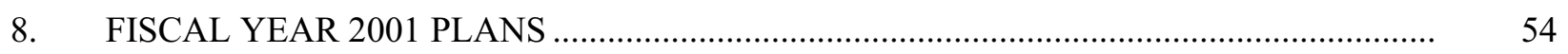

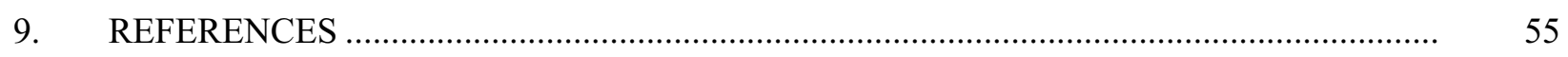

\section{FIGURES}

1. Approximate Grout Viscosity Based on Mixing Power Output ….................................... 8

2. Neutralized Simulated CsIX Sodium-Bearing Waste..................................................... 19

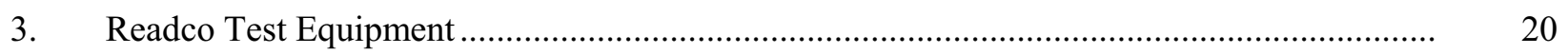

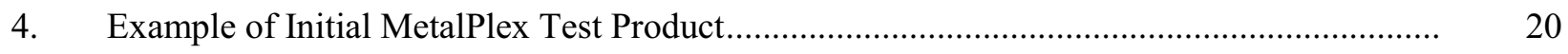

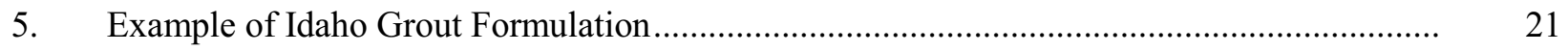

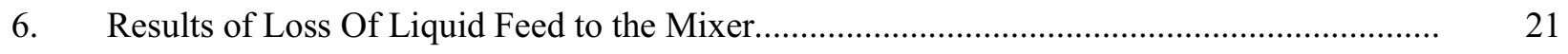

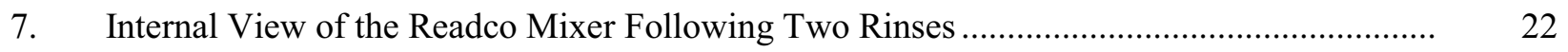

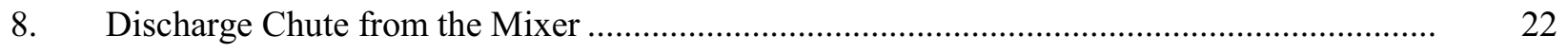

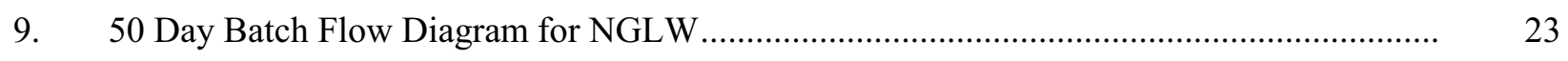

10. NGLW Concentrate Reverse Addition Curve ................................................................ 25

11. NGLW Concentrate Reverse Addition Curve …............................................................ 26

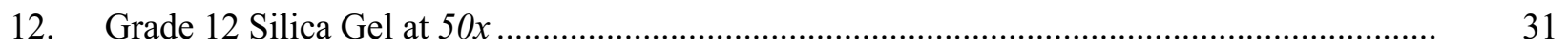

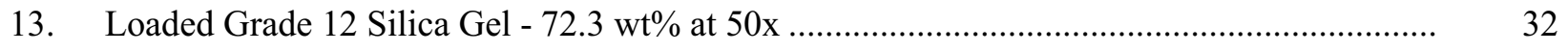




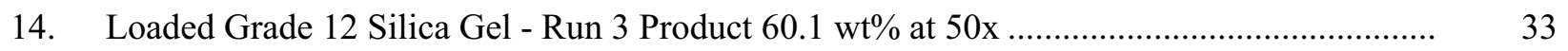

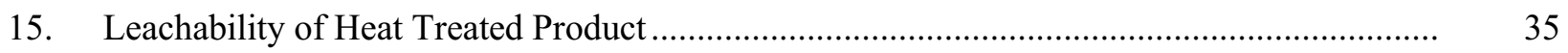

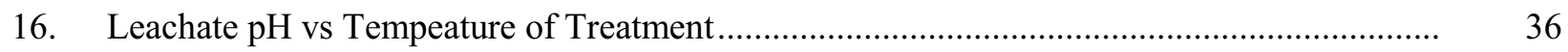

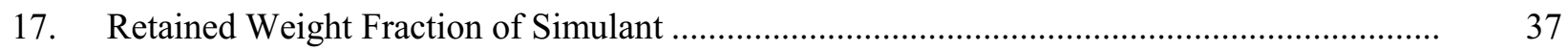

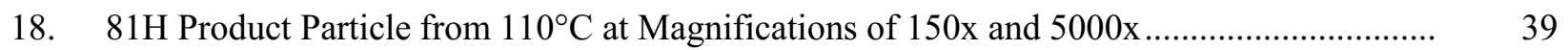

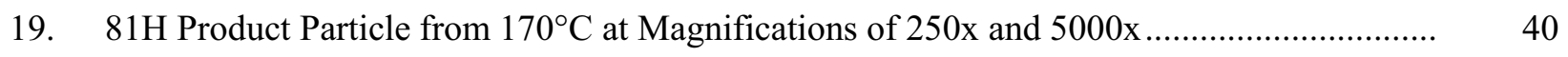

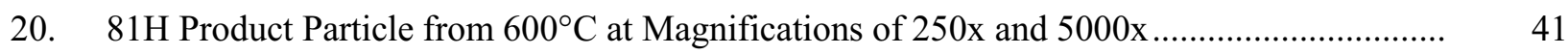

21. Silica Gel SBW Flowsheet -- 10 Liter/Minute Concentrated SBW ...................................... 43

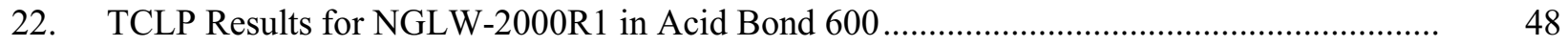

23. TCLP Results for CsIX-TRU in Acid-Bond 600 ........................................................... 50

24. Effect of Increased Acid-Bond 660 Absorbant on Freeze/Thaw Tests ................................ 51

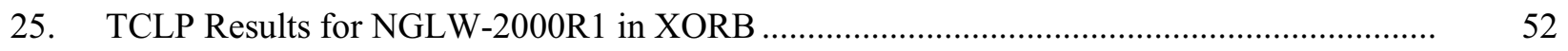

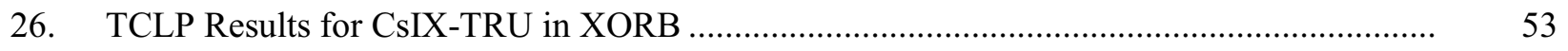

\section{TABLES}

1. Composition of Proposed CsIX Waste and Test Simulant ...............................................

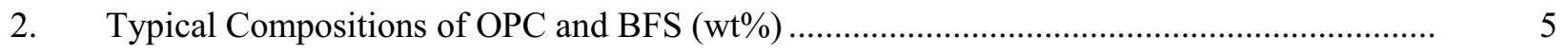

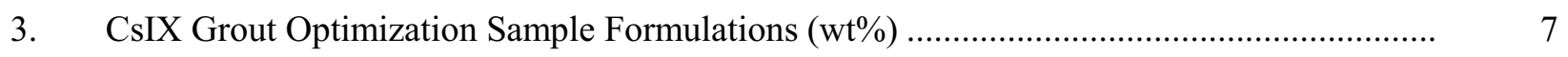

4. CsIX Grout Sample Mixing Power Requirements......................................................

5. Physical Properties of Cured Formulation Samples ....................................................... 10

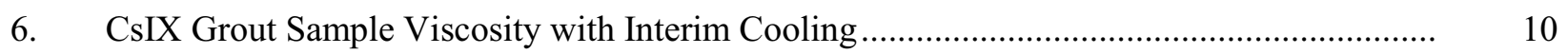

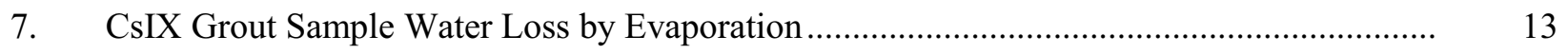

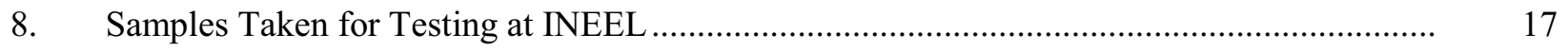

9. Mixer Test Sample Compressive Strength Results......................................................... 17

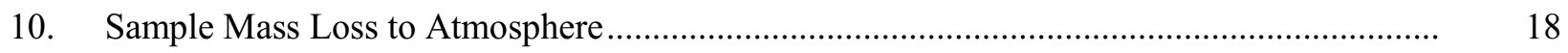




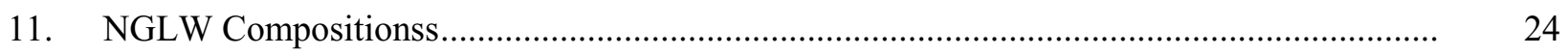

12. Grout Formulation for NGLW Mercury Tests............................................................... 26

13. Mercury Content in NGLw Simulant, Grout, and TCLP Extract .................................... 27

14. Concentrated Sodium Bearing Waste Composition...................................................... 29

15. Percent of Indicated Simulant Mass Remaining After Evaporation at Temperature.............. 30

16. Scanning Electron Microscope (SEM) Semi-Quantitative Analysis .................................... 32

17. Comparison of Silica Gel Experiments and Gupka Material with Sodium Bearing Waste

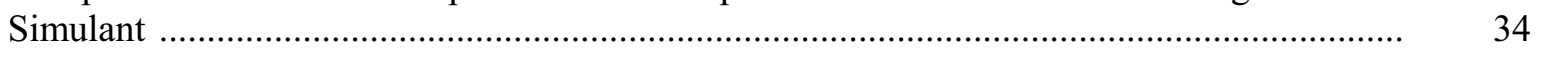

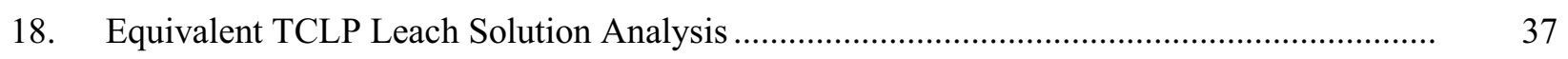

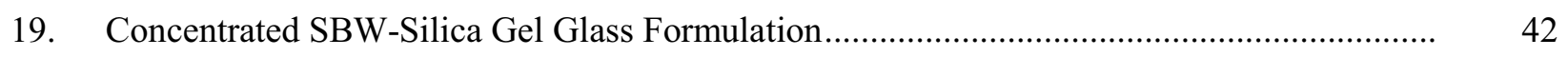

20. NGLW-2000R1: Newly Generated Liquid Waste Simulant Formulation............................. 46

21. CsIX-TRU: Cesium Ion Exchange Sodium-Bearing Waste Simulant Formulation .............. 47

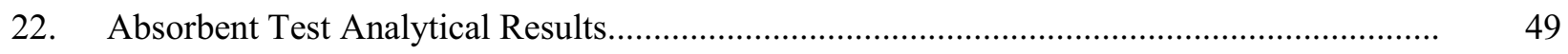

\section{APPENDICES}
A. ASME Peer Review of Low-Activity Waste Treatment and Tanks Focus Area Response
B. Heat of Neutralization Calculations
C. CPP-604 Grout Treatment of NGLW 


\section{IDAHO NUCLEAR TECHNOLOGY AND ENGINEERING CENTER LOW-LEVEL WASTE PROCESS TECHNOLOGY PROGRAM FY-2000 STATUS REPORT}

\section{INTRODUCTION}

The Idaho Nuclear Technology and Engineering Center (INTEC) High-Level Waste Program ${ }^{1}$ is to prepare the liquid sodium-bearing liquid waste and calcined solids for eventual disposal. Several alternative disposal processes have been explored for these wastes. Many of the processes include grouting as a disposal option for transuranic and low-level wastes. This research, performed by the LowLevel Waste Process Technology group, provides data to the Department of Energy (DOE) High-Level Waste and Facilities Disposition Environmental Impact Statement.

During fiscal year 2000 the following work was completed and discussed in this report: 1) Design of a grout pilot plant to grout wastes, 2) Treatment and disposal of sodium-bearing waste (SBW) as a transuranic waste to the Waste Isolation Pilot Plant, 3) Treatment and disposal of newly generated liquid waste (NGLW), and 4) Solidification of sodium-bearing waste on silica gel for interim storage or transport to another site. The grout formulation for sodium-bearing waste was optimized to improve fluid properties. It was determined that sodium-bearing waste could be solidified on silica gel at up to $50 \%$ of the dry product. Scoping experiments were completed on possible evaporation and grouting schemes for newly generated liquid waste. The design study showed a grout pilot plant and demonstration plant to be feasible for grouting of SBW and NGLW.

\section{LIQUID WASTE TREATMENT DEMONSTRATION}

During FY-2000 a design study ${ }^{2}$ was completed to determine the feasibility of newly generated liquid waste (NGLW) being grouted and disposed to a permitted land disposal site, such as Envirocare of Utah. This study was completed in February. In May, the project was expanded to include CsIX sodiumbearing waste as well. A conceptual design for both processes will be issued in October. The design includes testing NGLW and CsIX SBW in a cold pilot plant and a hot demonstration plant.

\subsection{Project Description}

The Liquid Waste Treatment Pilot Plant (LWTPP) is a cold demonstration plant that will provide the capability to develop and demonstrate the technology for treating non-radioactive liquid waste simulants, including neutralization, filtration, ion exchange for cesium extraction, material handling, and grouting. The simulants will include NGLW and sodium-bearing waste. The LWTPP is planned for building CPP-1634, the Technology Development Facility. The information obtained from the pilot plant will be used to verify the grouting process that is currently planned to be located in CPP-604.

Cold operations in the LWTPP will provide the opportunity to develop control measures to prevent overfilling drums, over neutralizing waste, and contaminating drums. It will also provide "hands on" provisions for remote handling, material handling, and training of operators. 
The NGLW simulant in the grouting process will be mixed and reacted with a $50 \%$ sodium hydroxide solution to a final $\mathrm{pH}$ of 12 to 12.5 . The alkaline waste will then be pumped to a batch tank that will overflow excess back into the reaction vessel. From the batch tank, the waste will gravity drain into a 55-gallon drum and mix with calcium hydroxide to complex the fluoride. Following the calcium hydroxide, portland cement and blast furnace slag are added and mixed thoroughly to form the grout. The blade used for in-drum mixing will be left in the waste drum to avoid clean up and contamination problems.

The sodium-bearing waste simulant requires solids separation/filtration and cesium removal prior to the grouting process. The solids separation will occur using either a bag type or cross flow filter. Simulant will then proceed through ion exchange columns for cesium extraction that will use either crystalline silicon titanate or AMP PAN. Following the ion exchange, the simulant will enter the grouting process, similar to the NGLW. The reaction vessel for the SBW is a jacket-cooled mixing vessel. Cooling of the vessel during the neutralization process is necessary due to the exothermic acid-base reaction between acidic SBW and calcium oxide. The waste will be partially neutralized with the calcium oxide to a $\mathrm{pH}$ of approximately 3 to 4 . If the $\mathrm{pH}$ is raised above 4, the waste begins to form a gel-like solution too viscous for processing. Following the partial neutralization and transfer to the batch vessel, the waste will gravity drain into a 55-gallon drum. Additional calcium oxide will be added in the drum to a predetermined level for the grouting process. Portland cement and blast furnace slag are then added and mixed thoroughly to form the grout.

The NGLW/SBW grouting process equipment for the LWTPP is mounted on a steel structure. The drums are transported through the process via a motorized conveying system. The grouting process, including the conveyor system, is designed to fit in the CPP-604 middle cell of the decommissioned Rare Gas Plant.

The planned schedule for the project is as follows:

$$
\begin{aligned}
& \text { Conceptual Design }^{3} \text { - October, } 2000 \\
& \text { Pilot Plant Title Design - December, } 2000 \\
& \text { Pilot Plant Start-Up - July, } 2001 \\
& \text { Demonstration Facility Title Design - FY-2002 } \\
& \text { Demonstration Facility Construction - FY-2003 } \\
& \text { Demonstration Facility Operation - FY-2004 }
\end{aligned}
$$

This schedule allow the pilot plant to be used for over a year to support title design of the demonstration facility.

The estimated cost for the demonstration facility is $\$ 4,500,000$. For a pilot plant with a single grout process train, the estimated cost is $\$ 1,400,000$. The second train would add $\$ 600,000$ to the cost of the pilot plant. To add the ion exchange column and solids filtering system an additional 1,400,000 would be needed. 


\subsection{ASME Peer Review}

Each year the Tanks Focus Area must conduct Congressional reviews of several of their funded projects. In August, members of the American Society of Mechanical Engineers (ASME) conducted a peer review of this grouting demonstration. Three of the review recommendations are: 1) The project should review commercial nuclear power plant low-level waste practices, 2) Stake holders should be brought into the project early, and 3) Communications are needed with WIPP to resolve RCRA listed code for hydrofluoric acid. DOE and the State of Idaho have briefed on the project; however, the local advisory board has not. Items 1 and 2 will be worked next fiscal year. The program office is working on item 3 as part of the overall program. In general, the ASME team concluded the NGLW grouting is ready to proceed for wastes to Envirocare; however, SBW CsIX needs more work to resolve waste acceptance criteria issues. A copy of the ASME report and the Tanks Focus Area response are attached as Appendix A.

\subsection{Future Plans}

Initially as noted above, the grouting demonstration was to process specific NGLW streams. However, with updated schedules, the desired waste streams may not be available when the demonstration facility is ready. The HLLWE is scheduled to operate from FY-01 to FY-03 and the demonstration facility will be constructed during FY-03. A white paper was prepared to determine if NGLW produced after 2005 could be processed to meet Envirocare waste acceptance criteria (see Appendix C). Due to the projected high radioactive content, the grouted waste would not meet Envirocare's criteria.

The Department of Energy Idaho Operations Office has mandated that after 2005 NGLW is to be diverted from the tank farm vessels. Thus alternate storage and processing is needed for this waste. One possibility after the HLLWE operation is complete, the process equipment evaporator could be flushed and rinsed sufficiently to remove the listed waste codes. Without the listed waste codes, NGLW could be sent to other waste disposal sites, such as the Nevada Test Site, as a low-level waste, rather than a mixed waste. The Nevada Test Site can accept higher levels of radioactive nuclides than Envirocare.

In conclusion, first, the projected NGLW waste after 2005 needs to be characterized. Only limited samples have been taken on projected streams. Second, the concept of sending NGLW to alternative disposal sites as non-listed waste needs to be investigated. Third, interim storage should also be investigated such that the waste could be processed later with or following the sodium-bearing waste.

\section{SBW CSIX GROUT DEVELOPMENT}

In January 1990, the U.S. Environmental Protection Agency (EPA) issued to the Department of Energy (DOE) a Notice of Noncompliance because the Idaho Nuclear Technology and Engineering Center (INTEC) tank farm facility (TFF) did not meet the secondary containment requirements of the Resource Conservation and Recovery Act (RCRA). As a part of the Settlement Agreement between DOE and the State of Idaho, the TFF tanks are to be taken out of service by December 31, 2012. An obvious element of the TFF tanks closure is the removal, treatment and disposal of the remaining liquid mixed wastes. Currently the TFF contains a total waste inventory of approximately 1.5 million gallons. Due to the relatively high concentration of sodium in the waste, it is referred to as sodium-bearing waste (SBW).

Several potential options have been proposed for the treatment and disposal of existing SBW. Of 
the options in which grouting technologies play a significant role, the most preferred is the Cesium IonExchange (CsIX) option. This treatment option includes: 1) separating the cesium from the liquid by ion exchange, 2) solidifying the liquid using alkaline cement-based grout additives, and 3) disposing of the solid as contact-handled transuranic (TRU) waste at the Waste Isolation Pilot Plant (WIPP) located in New Mexico. This cesium-separated sodium-bearing waste will be referred to as CsIX waste throughout the remainder of this report.

The calculated average composition of CsIX waste (after Cs separation and concentration), without the radioactive components, is presented in Table 1. All CsIX waste simulant used in this testing contained none of the toxic elements. The CsIX waste simulant composition is also presented in Table 1.

Table 1. Composition of Proposed CsIX Waste (Excluding Radioisotopes) and Test Simulant

\begin{tabular}{|c|c|c|}
\hline Species & $\begin{array}{l}\text { Calculated CsIX } \\
\text { Waste (M) }\end{array}$ & $\begin{array}{c}\text { Non-Hazardous CsIX } \\
\text { Waste Test Simulant }(\underline{M})\end{array}$ \\
\hline $\mathrm{H}$ & 1.96 & 1.96 \\
\hline $\mathrm{Ag}$ & $2.74 \times 10^{-5}$ & \\
\hline $\mathrm{Al}$ & $6.03 \times 10^{-1}$ & $6.03 \times 10^{-1}$ \\
\hline As & $7.16 \times 10^{-5}$ & \\
\hline B & $1.89 \times 10^{-2}$ & $1.89 \times 10^{-2}$ \\
\hline $\mathrm{Ba}$ & $6.10 \times 10^{-5}$ & \\
\hline $\mathrm{Ca}$ & $5.24 \times 10^{-2}$ & $5.24 \times 10^{-2}$ \\
\hline $\mathrm{Cd}$ & $5.12 \times 10^{-3}$ & \\
\hline $\mathrm{Cl}$ & $2.92 \times 10^{-2}$ & $2.92 \times 10^{-2}$ \\
\hline $\mathrm{Cr}$ & $5.34 \times 10^{-3}$ & \\
\hline Cs & $8.44 \times 10^{-9}$ & \\
\hline $\mathrm{F}$ & $9.08 \times 10^{-2}$ & $9.08 \times 10^{-2}$ \\
\hline $\mathrm{Fe}$ & $2.22 \times 10^{-2}$ & $2.22 \times 10^{-2}$ \\
\hline $\mathrm{Hg}$ & $1.68 \times 10^{-3}$ & \\
\hline K & $1.73 \times 10^{-1}$ & $1.73 \times 10^{-1}$ \\
\hline $\mathrm{Mn}$ & $1.34 \times 10^{-2}$ & $1.34 \times 10^{-2}$ \\
\hline Mo & $6.87 \times 10^{-4}$ & $6.87 \times 10^{-4}$ \\
\hline $\mathrm{Na}$ & 1.56 & 1.56 \\
\hline $\mathrm{Ni}$ & $2.21 \times 10^{-3}$ & \\
\hline $\mathrm{NO}_{3}$ & 5.64 & 5.64 \\
\hline $\mathrm{Pb}$ & $1.07 \times 10^{-3}$ & \\
\hline $\mathrm{PO}_{4}$ & $7.15 \times 10^{-3}$ & $7.15 \times 10^{-3}$ \\
\hline $\mathrm{Se}$ & $1.43 \times 10^{-5}$ & \\
\hline $\mathrm{Sr}$ & $2.04 \times 10^{-5}$ & $2.04 \times 10^{-5}$ \\
\hline $\mathrm{SO}_{4}$ & $4.08 \times 10^{-2}$ & $4.08 \times 10^{-2}$ \\
\hline $\mathrm{Zr}$ & $1.33 \times 10^{-2}$ & $1.33 \times 10^{-2}$ \\
\hline
\end{tabular}

Extensive development work was performed during FY99 to develop baseline grout formulations for WIPP disposal of CsIX waste. ${ }^{4}$ Although the waste acceptance criteria (WAC) for WIPP includes several requirements relative to both radioisotope concentrations and transportation to the disposal facility 
(i.e. truckload total weight), essentially the only physical requirement is that the final waste product must be solid ( $<2$ liters total residual liquid per 55-gallon drum). This minimal WAC promotes the pursuit of maximum waste loading at the expense of waste form quality. Conversely, political pressure may deem it prudent to produce TRU waste forms that meet self-imposed criteria that are more stringent than the WIPP WAC minimum.

Two separate approaches had been previously implemented for the development of solidification methods for potential CsIX waste: the first maximizing the waste loading; the second satisfying the more stringent Nuclear Regulatory Commission (NRC) criteria for Class C low-level waste. Although success was realized in both development schemes, only the approach involving maximizing the waste loading was continued beyond the initial development. The high expenses associated with processing the waste, interim storage of the waste forms prior to WIPP disposal, handling and transporting the waste, and finally disposing of the waste at WIPP, all necessitate the minimization of the total waste form volume.

\subsection{Baseline CsIX Grout Formulation}

During the above-mentioned initial grout development efforts, it was discovered that CsIX waste loadings of $80+\mathrm{wt} \%$ could be successfully attained by using $\mathrm{CaO}$ (calcium oxide or quicklime) or $\mathrm{Ca}(\mathrm{OH})_{2}$ (calcium hydroxide or slaked lime) in the grout formulation so that a significant excess of calcium hydroxide is still present after all immediate chemical reactions (i.e. acid neutralization) take place. This addition of sufficient $\mathrm{CaO}$ to an aqueous waste stream: 1) directly reacts with equivalent moles of water in the waste to form $\left.\mathrm{Ca}(\mathrm{OH})_{2}, 2\right)$ neutralizes the waste acidity, 3) precipitates and immobilizes most toxic metals, 4) dramatically reduces or eliminates free liquids by adsorption, and 5) produces an alkaline environment and calcium ion availability that both strongly promote cementitious reactions with pozzolanic materials.

From this discovery, a high waste loading baseline grout formulation was developed. In addition to the excess amount of $\mathrm{CaO}$ used, minor amounts of Type I/II ordinary portland cement (OPC) and blast furnace slag (BFS) were also added for specific purposes. OPC was a component of the baseline formulation to assure and expedite the grout setting. BFS was includes in the formulation to provide both pozzolanic ingredients and a sulfide source for mercury immobilization. Typical compositions of these two grout ingredients are presented in Table 2.

To provide more assurance and flexibility for changes in waste stream and grout formulation compositions, the waste loading was dropped to $70 \mathrm{wt} \%$. The original CsIX grout baseline formulation consisted of $14 \mathrm{wt} \% \mathrm{CaO}, 9 \mathrm{wt} \% \mathrm{BFS}, 7 \mathrm{wt} \%$ OPC, and $70 \mathrm{wt} \%$ waste solution.

Table 2. Typical Compositions of OPC and BFS (wt $\%)$

\begin{tabular}{|l|c|c|c|c|c|c|c|}
\hline & $\mathbf{S i O}_{\mathbf{2}}$ & $\mathbf{A l}_{\mathbf{2}} \mathbf{O}_{\mathbf{3}}$ & $\mathbf{F e}_{\mathbf{2}} \mathbf{O}_{\mathbf{3}}$ & $\mathbf{C a O}$ & $\mathbf{M g O}$ & $\mathbf{S O}_{\mathbf{3}}$ & $\mathbf{S}^{2-}$ \\
\hline Type I/II OPC & 21.3 & 5.0 & 2.9 & 64.0 & 2.8 & 2.6 & \\
\hline BFS & 34.0 & 10.0 & 0.8 & 41.0 & 11.0 & & 2 \\
\hline
\end{tabular}

The $\mathrm{CaO}$ originally purchased and used in all of the FY99 development work and a considerable portion of this testing was suspected to have hydrated from extended exposure to atmospheric water vapor. As a part of this testing, analysis of a sample of this "CaO" confirmed the suspicion. The "quicklime" being used was in fact slaked lime, consisting of approximately $90 \mathrm{wt} \%$ calcium hydroxide, and $10 \mathrm{wt} \%$ calcium carbonate. The CsIX grout baseline formulation was clarified for the use of either 
$\mathrm{CaO}$ or $\mathrm{Ca}(\mathrm{OH})_{2}$. If $\mathrm{CaO}$ (quicklime) is used, the baseline formulation consists of $11 \mathrm{wt} \% \mathrm{CaO}, 11 \mathrm{wt} \%$ $\mathrm{BFS}$, and $8 \mathrm{wt} \% \mathrm{OPC}$. If $\mathrm{Ca}(\mathrm{OH})_{2}$ (slaked lime) is used, the baseline formulation consists of $14 \mathrm{wt} \%$ $\mathrm{Ca}(\mathrm{OH})_{2}, 9 \mathrm{wt} \% \mathrm{BFS}$, and $7 \mathrm{wt} \%$ OPC.

The resulting monolithic waste forms exceed the requirements of the WIPP WAC in that they are completely liquid free, have reasonable compressive strengths (over $100 \mathrm{psi}$ ), and pass the RCRA LDR leach test for toxic metals. Note that although OPC and BFS were selected for this application because of specific beneficial properties, numerous other pozzolanic additives (silica fume, silica gel, clay, fly ash, etc.) could be substituted for them with the final waste form still meeting the WIPP WAC. The single unique element of the formulation that makes the high waste loading possible is the significant excess of $\mathrm{Ca}(\mathrm{OH})_{2}$ after all initial chemical reactions with the waste have taken place.

\subsection{CsIX Grout Formulation Optimization Testing}

Although the baseline formulation development was extremely successful, some potential problems were identified:

1. The baseline mixture is quite thick and viscous (very similar to bread dough). Significant problems could easily exist in a full-scale facility with respect to mixing and pouring the grout.

2. With the high waste loading, a significant fraction of the waste liquid is not chemically bound. Significant evaporation does occur when cured waste form samples are exposed to the environment. Concern was raised that this evaporation and later re-condensing could occur, leaving free liquid on top of the solidified waste contained in 55-gal drums. This happening could potentially render the waste forms unacceptable for WIPP disposal ( $>2$ liters free liquid per 55-gal drum). Thermal cycling would certainly increase the potential for this problem to occur.

Additional tests have been performed to address both of the above potential problems.

The compositions of all grout samples prepared for these tests are presented in Table 3. CsOpt 1 is the original baseline formulation. CsOpt 2, 8, and 17 are formulations where sodium hydroxide is substituted for different fractions of the baseline calcium oxide. In addition to the sodium hydroxide substitution, CsOpt 17 also has a total alkaline metal oxide $(\mathrm{NaOH}+\mathrm{CaO})$ reduction (from the baseline formulation). CsOpt 6, 9, and 19 are formulations where magnesium oxide is substituted for different fractions of the baseline $\mathrm{CaO}$ and the total alkaline metal oxide $(\mathrm{MgO}+\mathrm{CaO})$ is slightly reduced. CsOpt 3 and 4 are formulations with different reductions in the amount of $\mathrm{CaO}$ used. CsOpt 10 through 15 are formulations testing the reactivity of newly calcined $\mathrm{CaO}$. CsOpt 5 is a formulation exploring the potential of using just $\mathrm{CaO}$ and BFS (no OPC). CsOpt 16 and 18 are formulations exploring the potential of using just $\mathrm{CaO}$ and $\mathrm{OPC}$ (no BFS). CsOpt 20 is a formulation using calcined $\mathrm{CaO}$ at a reduced level, and an increased amount of BFS.

Generally, reductions in $\mathrm{CaO}$ are accompanied by equivalent increases in OPC and/or BFS to maintain a $70 \mathrm{wt} \%$ waste loading. Exceptions to this (CsOpt 12-15) are all formulations using newly calcined $\mathrm{CaO}$.

Although the optimization tests are described separately in the following sections, they were conducted concurrently. Generally, more than one sample of each grout formulation was prepared, and each test for a specific grout formulation was conducted using a separate sample.

In all cases with the described optimization testing, toxic elements were excluded from the CsIX waste simulant to minimize the production of hazardous waste. Thus, no TCLP leach tests were 
conducted on the various grout formulation samples. Note, however, that similar grout samples prepared during the initial CsIX development effort used waste simulant containing toxic elements at the same average concentrations expected in the actual waste. These samples, prepared using approximately the same concentrations of the grout ingredients that are responsible for the immobilization of toxic metals ( $\mathrm{CaO}$ and BFS), have successfully passed the RCRA TCLP leach test. Generally, the formulation changes made from this optimization testing should not alter the immobilization mechanisms (hydroxide precipitation, sulfide precipitation, and oxidation potential reduction) in place. Exceptions to this are samples CsOpt 16 and 18, where BFS is not used, and the later two immobilization mechanisms listed

Table 3. CsIX Grout Optimization Sample Formulations (wt\%)

\begin{tabular}{|c|c|c|c|c|c|c|c|c|}
\hline Sample & $\begin{array}{c}\text { CsIX } \\
\text { Waste } \\
\text { Simulant }\end{array}$ & $\begin{array}{c}\text { CaO } \\
\text { (old) } \\
* *\end{array}$ & $\begin{array}{c}\text { CaO } \\
\text { (new) } \\
* * *\end{array}$ & $\mathbf{C a}(\mathbf{O H})_{2}$ & NaOH & MgO & $\begin{array}{c}\text { OPC } \\
\text { I/II }\end{array}$ & BFS \\
\hline CsOpt 1 & 70.0 & 14.0 & & & & & 7.0 & 9.0 \\
\hline CsOpt 2 & 70.0 & 10.0 & & & 4.0 & & 7.0 & 9.0 \\
\hline CsOpt 3 & 70.0 & 10.0 & & & & & 10.0 & 10.0 \\
\hline CsOpt 4 & 70.0 & 12.0 & & & & & 9.0 & 9.0 \\
\hline CsOpt 5 & 70.0 & 12.0 & & & & & & 18.0 \\
\hline CsOpt 6 & 70.0 & 6.0 & & & & 6.0 & 9.0 & 9.0 \\
\hline CsOpt 7 & 70.0 & & & 14.0 & & & 7.0 & 9.0 \\
\hline CsOpt 8 & 70.0 & 6.0 & & & 8.0 & & 7.0 & 9.0 \\
\hline CsOpt 9 & 70.0 & 8.0 & & & & 4.0 & 9.0 & 9.0 \\
\hline CsOpt 10 & 70.0 & & 10.0 & & & & 10.0 & 10.0 \\
\hline CsOpt 11 & 70.0 & & 12.0 & & & & 9.0 & 9.0 \\
\hline CsOpt 12 & 72.9 & & 10.4 & & & & 8.3 & 8.3 \\
\hline CsOpt 13 & 74.5 & & 8.5 & & & & 8.5 & 8.5 \\
\hline CsOpt 14 & 71.4 & & 8.2 & & & & 12.2 & 8.2 \\
\hline CsOpt 15 & 73.8 & & 9.3 & & & & 8.4 & 8.4 \\
\hline CsOpt 16 & 70.0 & 10.0 & & & & & 20.0 & \\
\hline CsOpt 17 & 70.0 & 4.0 & & & 10.0 & & 8.0 & 8.0 \\
\hline CsOpt 18 & 70.0 & 12.0 & & & & & 18.0 & \\
\hline CsOpt 19 & 70.0 & 4.0 & & & & 8.0 & 9.0 & 9.0 \\
\hline CsOpt 20 & 70.0 & & 8.0 & & & & 8.0 & 14.0 \\
\hline
\end{tabular}

** This was the original $\mathrm{CaO}$ used, which was later discovered to have been almost completely hydrated to $\mathrm{Ca}(\mathrm{OH})_{2}$.

*** This $\mathrm{CaO}$ was prepared by calcining the original $\mathrm{CaO}$ at $850^{\circ} \mathrm{C}$ for several hours. This resulted in a mass reduction of approximately $25 \%$.

above are absent. In these cases, mercury leaching above the RCRA land disposal restriction limits would be expected. In all cases, however, verification testing using waste simulants containing the toxic elements will be required prior to final formulation recommendations. 


\subsection{Grout Viscosity Reduction Testing}

Of major concern with the baseline grout formulation (CsOpt 1 ) is the potential for mixing and/or pouring problems due to the demonstrated high viscosity of the mixture. It had been noted during the development of the baseline formulation that although the grout mixture has the consistency of a heavy bread dough, this high viscosity is encountered only at the very end of the $\mathrm{CaO}$ addition. Furthermore, only slight viscosity increases resulted from the subsequent addition of either OPC or BFS. This information supported the idea that a minor decrease in the amount of $\mathrm{CaO}$ used might significantly decrease the viscosity of the mixture. It was also speculated that decreasing the total amount of $\mathrm{CaO}$ used, by using a different alkaline chemical to accomplish the majority of the acid neutralization of the CsIX waste, might also result in a decreased grout mix viscosity.

Laboratory test experience, verified by reaction heat generation calculations (Appendix B), shows that near-boiling conditions are expected with the addition of the designated baseline quantity of $\mathrm{CaO}$ to the acidic waste. It is likely that for a full-scale grout immobilization facility, heat exchanger cooling would be required during the initial acid neutralization step, when most of the heat generation takes place. Additional testing was deemed necessary to assure that a dramatic increase in mixture viscosity will not occur as a result of cooling.

\subsubsection{Test Description}

A Lightnin Mixer (Model L1UO3) was used to perform the grout mixing and to measure and indicate power output requirements for the mixing operations of the various grout formulations. Approximate viscosity values were determined for each sample by first measuring the mixing power requirement (Watts) for that sample (with all formulation ingredients added), and converting that value to viscosity (centipoise). To perform the conversion, a graph was developed using the same mixing apparatus and power values measured for various viscosity standards (Figure 1). The mixing blade used in all cases was fabricated using specifications obtained from a report provided by AEA which describes a similar cement grout rheology determination study. ${ }^{5}$ Generally, grout samples were $250 \mathrm{~g}$ total. The blade was positioned in the mix vessel at the same depth for each grout formulation. The blade rotational mix speeds were constant at $500 \mathrm{rpm}$. Estimated viscosities are based on the stable mixing power output values.

Figure 1. Approximate Grout Viscosity Based on Mixing Power Output

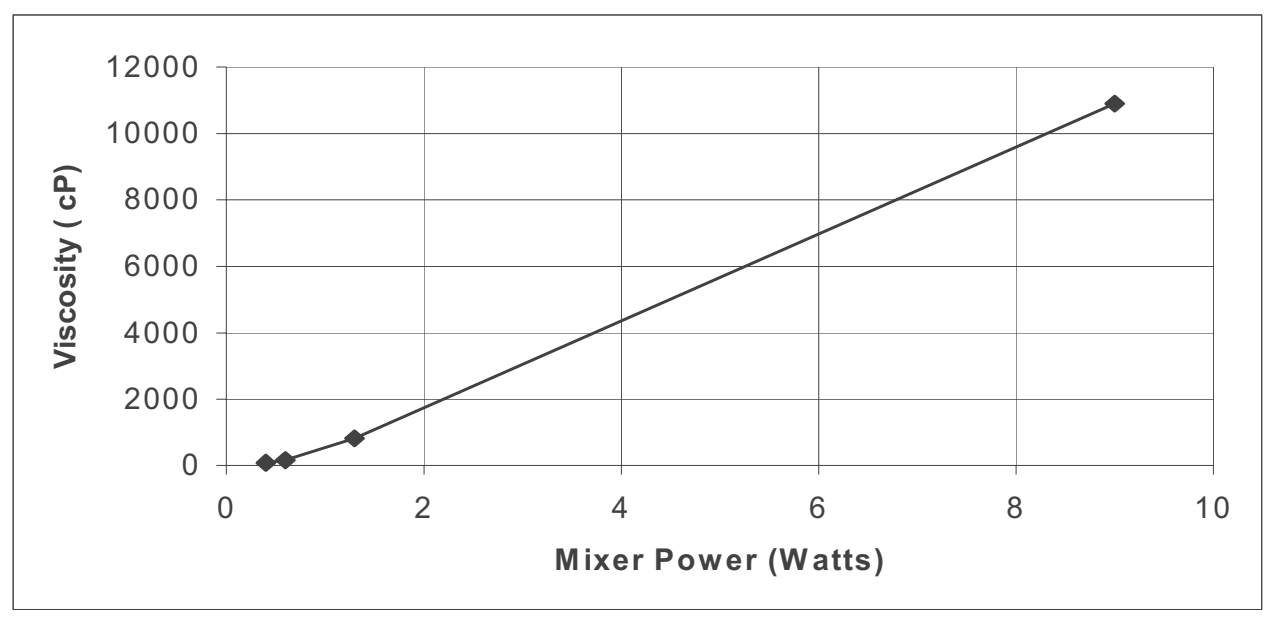


Two additional viscosity determination tests were performed, similar to that described above, except that the mixtures were allowed to cool following the addition of the specific alkaline metal oxide(s) and/or hydroxide used $(\mathrm{CaO}, \mathrm{NaOH}$, and/or $\mathrm{MgO})$, but prior to the addition of the OPC and BFS. Both of these tests were performed with samples of formulations CsOpt 1, 2, 3, 4, and 6, only. The two tests differed in that the cooling period for the first was overnight, while the cooling period for the second was over a three-day weekend.

\subsubsection{Test Results and Discussion}

The peak mixing power requirements, the stabilized power requirements, and the approximate viscosity values for the various test formulations are presented in Table 4. Although reduced viscosity was the objective of this testing, the effects of the formulation modifications, to the physical properties of the final product monoliths, were also measured. With respect to WIPP disposal, the appearance of free liquid as a result of a formulation modification is viewed as extremely undesirable. Although compressive strength is not a requirement for WIPP disposal, it is viewed as a desirable, measurable property that at least gives an indication of waste form integrity. Samples with free liquid present are identified in Table 5. Individual sample compressive strengths are also presented in Table 5.

The peak mixing power requirements, the stabilized power requirements, and the approximate viscosity values for the interim cooling test with formulations samples CsOpt 1, 2, 3, 4, and 6 are presented in Table 6.

Table 4. CsIX Grout Sample Mixing Power Requirements

\begin{tabular}{|c|c|c|c|}
\hline \multirow{2}{*}{ Sample } & \multicolumn{2}{|c|}{ Mixing Power Requirements (Watts) } & \multirow{2}{*}{$\begin{array}{c}\text { Estimated Viscosity } \\
\text { (cP) }\end{array}$} \\
\cline { 2 - 4 } & & Stable & 5200 \\
\hline CsOpt 1 & 6.3 & 4.6 & 2500 \\
\hline CsOpt 2 & 3.1 & 2.6 & $<100$ \\
\hline CsOpt 3 & 0.2 & 0.1 & 1100 \\
\hline CsOpt 4 & 2.1 & 1.5 & - \\
\hline CsOpt 5 & - & - & 600 \\
\hline CsOpt 6 & 1.5 & 1.0 & 3100 \\
\hline CsOpt 7 & 4.6 & 3.0 & 300 \\
\hline CsOpt 8 & 0.8 & 0.6 & 7800 \\
\hline CsOpt 9 & 7.7 & 6.6 & 6300 \\
\hline CsOpt 10 & 9.3 & 5.5 & 10600 \\
\hline CsOpt 11 & 10.5 & 8.8 & 7500 \\
\hline CsOpt 12 & 11.2 & 6.4 & 300 \\
\hline CsOpt 13 & 1.0 & 0.6 & 600 \\
\hline CsOpt 14 & 1.5 & 1.0 & 1750 \\
\hline CsOpt 15 & 3.8 & 2.0 & 300 \\
\hline CsOpt 16 & 1.3 & 0.6 & $<100$ \\
\hline CsOpt 17 & 0.2 & 0.1 & 1100 \\
\hline CsOpt 18 & 2.2 & 1.5 & 400 \\
\hline CsOpt 19 & 0.9 & 0.7 & 900 \\
\hline CsOpt 20 & 1.8 & 1.3 & \\
\hline
\end{tabular}


Table 5. Physical Properties of Cured Formulation Samples

\begin{tabular}{|c|c|c|c|}
\hline Sample & Cure Period (days) & Free Liquid & $\begin{array}{c}\text { Compressive } \\
\text { Strength (psi) }\end{array}$ \\
\hline CsOpt 1 & 33 & No & 370 \\
\hline CsOpt 2 & 33 & No & 300 \\
\hline CsOpt 3 & 33 & No & 210 \\
\hline CsOpt 4 & 33 & No & 430 \\
\hline CsOpt 5 & - & Yes & NA \\
\hline CsOpt 6 & 33 & No & 450 \\
\hline CsOpt 7 & 60 & No & 410 \\
\hline CsOpt 8 & 61 & No & 250 \\
\hline CsOpt 9 & 60 & No & 310 \\
\hline CsOpt 10 & 60 & No & 860 \\
\hline CsOpt 11 & 60 & No & 800 \\
\hline CsOpt 12 & 60 & No & 480 \\
\hline CsOpt 13 & 60 & No & 400 \\
\hline CsOpt 14 & 60 & No & 640 \\
\hline CsOpt 15 & 60 & No & 510 \\
\hline CsOpt 16 & 61 & No & 310 \\
\hline CsOpt 17 & - & Yes & NA \\
\hline CsOpt 18 & 48 & No & 270 \\
\hline CsOpt 19 & 33 & No & 220 \\
\hline CsOpt 20 & 46 & No & 960 \\
\hline
\end{tabular}

Table 6. CsIX Grout Sample Viscosity With Interim Cooling

\begin{tabular}{|c|c|c|c|}
\hline \multicolumn{4}{|c|}{ Test 1 (Cooling Overnight) } \\
\hline \multirow[t]{2}{*}{ Sample } & \multicolumn{2}{|c|}{ Mixing Power Requirements (Watts) } & \multirow{2}{*}{$\begin{array}{c}\text { Estimated Viscosity } \\
\text { (cP) }\end{array}$} \\
\hline & Peak & Stable & \\
\hline CsOpt 1 & - & 4.1 & 4500 \\
\hline CsOpt 2 & 5.3 & 3.8 & 4100 \\
\hline CsOpt 3 & 1.1 & 0.6 & 300 \\
\hline CsOpt 4 & 1.9 & 1.8 & 1500 \\
\hline CsOpt 6 & 1.0 & 0.7 & 400 \\
\hline \multicolumn{4}{|c|}{ Test 2 (90-Hour Cooling) } \\
\hline CsOpt 1 & 8.6 & 6.2 & 7200 \\
\hline CsOpt 2 & 9.9 & 9.1 & 11000 \\
\hline CsOpt 3 & 0.4 & 0.2 & 100 \\
\hline CsOpt 4 & 3.1 & 2.8 & 2800 \\
\hline CsOpt 6 & 1.4 & 1.0 & 600 \\
\hline
\end{tabular}


From the test results in Table 4, it is obvious that the viscosity of the grout mix is extremely sensitive to the quantity of $\mathrm{CaO}$ used. From that of the baseline formulation (CsOpt 1), the viscosity can be reduced over $75 \%$ by reducing the total $\mathrm{CaO}$ added by approximately $15 \%$ (CsOpt 4 ), with apparently no detrimental effect to the compressive strength. The results also strongly indicate that the viscosity of the baseline formulation mixture can be significantly reduced by substituting either $\mathrm{NaOH}$ or $\mathrm{MgO}$ for the portion of $\mathrm{CaO}$ used for acid neutralization (CsOpt 2, 6, 8, and 19). Although viscosity improvements are realized with these chemical substitutions, results suggest caution should be taken. Decreases in grout compressive strengths (Table 5) are suggested to be the result of $\mathrm{CaO}$ substitution with either $\mathrm{NaOH}$ (CsOpt 2 and 8) or too large an amount of $\mathrm{MgO}$ (CsOpt 19). Furthermore, an unexplained reaction did occur when using $\mathrm{MgO}$ that dramatically increased the viscosity of the mixture (CsOpt 9). This phenomenon was verified when the same high viscosity was realized during the preparation of a second sample of this formulation. This phenomenon is especially puzzling in that it occurred with the grout formulation involving the least amount of $\mathrm{CaO}$ substitution from the baseline formulation, whereas no such reaction was evident in the formulations having a higher quantity of $\mathrm{CaO}$ substituted with $\mathrm{MgO}$ (CsOpt 6 and 19).

Also shown in Table 5, grout formulations CsOpt 5 and 17 both resulted in a significant amount of free liquid present after the curing period. The sample of formulation CsOpt 17 had solidified into a hard monolith, but had an unacceptable level of free liquid sitting on the sample surface (approximately $1 / 2$-inch liquid atop $2 \frac{1}{2}$ inches of solid). Apparently, from the original baseline formulation, the absolute limit on $\mathrm{CaO}$ substitution with $\mathrm{NaOH}$ is between the amounts substituted in formulations CsOpt 8 and 17 ( 57 to $71 \mathrm{wt} \% \mathrm{CaO}$ substitution). The sample of formulation CsOpt 5 not only had an unacceptable volume of clear liquid sitting on the top surface similar to the above described sample, but had also remained soft, not setting at all. This formulation, consists of just $\mathrm{CaO}$ and $\mathrm{BFS}$ (no OPC). Apparently, the amount of $\mathrm{CaO}$ added offered insufficient mixture alkalinity to enable adequate dissolution of and reaction with the BFS. Although the CsOpt 5 sample had been prepared using the original, hydrated $\mathrm{CaO}$, and better results may have resulted with the use of "fresh" $\mathrm{CaO}$, the results still indicate that OPC should be included in the formulation to minimize risk.

Although not indicated in the above tables, the slow curing of formulation CsOpt 3 samples warrants discussion. This formulation has a significant drop in $\mathrm{CaO}$ from the baseline formulation (29 $\mathrm{wt} \%$ ). The samples made using this formulation took an extremely long time to set, and remained relatively soft after up to 2 week of curing. Although these samples did eventually harden, achieve a reasonable compressive strength within a 28 -day period, and at no time showed evidence of free liquid being present, the slow strength gain strongly suggests that a $\mathrm{CaO}$ minimum is close. This very slow setting also highlights the importance of excess $\mathrm{CaO}\left(\right.$ or $\left.\mathrm{Ca}(\mathrm{OH})_{2}\right)$ in the baseline formulation. Although the baseline formulation reduction in $\mathrm{CaO}$ is accompanied by an equal mass increase in OPC plus BFS, the physical strength of the monolith still suffers.

With respect to the viscosity testing involving sample cooling, no significant viscosity changes are noted for samples that were only allowed to set (cool) over night (approximately 15 hours). Same formulation samples allowed to cool/set over a three-day weekend (approximately 90 hours), however, generally showed a viscosity increase (except for the formulation CsOpt 3 sample, which showed a decrease). These viscosity changes are generally relatively small, and could be dismissed as within the expected ranges of error. The viscosity change for formulation CsOpt 2, however, is an exception. The dramatic viscosity increase for that sample strongly indicates that some solidification reactions involving $\mathrm{NaOH}$ are slowly continuing beyond the acid neutralization and the aluminum and iron hydroxides precipitation and re-dissolution. Further investigation would be required to determine which chemical precipitates are forming over the several-day period. The test results suggest, however, that the conditions of this CsOpt 2 formulation test need to be avoided as the viscosity results are counter to the intent of the chemical substitution. 


\subsection{Water Retention Testing}

Previous baseline formulation CsIX grout samples, when left exposed to the environment for an extended period, have shown significant mass loss (in excess of $30 \mathrm{wt} \%$ ), due to evaporation, over time periods of several weeks. Conversely, other baseline formulation CsIX grout samples that have been cured and continuously contained in sealed containers (glass jars) have solidified, and have never (over periods of several months) shown signs of free liquid being present. Currently, it is unclear whether the mass loss via evaporation is an advantage or disadvantage. It has been argued that 55 -gal drums filled with this grout could be vented (with an attached HEPA filter) and the interim storage facility could have a controlled atmosphere (heated, circulated air). Under these conditions, mass loss via evaporation could be an advantage, as truck shipments to WIPP are extremely weight restricted. Significant mass loss per given volume would potentially allow more waste drums to be shipped per shipment.

Conversely, concerns have been voiced over free water appearing in the waste drums due to evaporation and condensation, contamination accompanying the escaped water vapor, condensate accumulating in the interim storage facility, etc.

A test was conducted to determine the extent of evaporation mass loss for each of the grout formulations. Each formulation change was expected to at least somewhat change the total mass loss due to evaporation. For example, the degrees of hydration for calcium nitrate and magnesium nitrate is different. These salts are expected products from waste neutralization with formulations CsOpt 1 and CsOpt 6, respectively. Thus, the amount of "unbound" water available for evaporation is expected to also be different. Differences in mass loss were, however, expected to be relatively small, and in no case was a significant reduction in mass loss expected.

\subsubsection{Test Description}

The same grout samples that had been "crushed" in the compressive strength test were used for this testing. Following the compressive strength test, pieces of each formulation sample were placed in individual plastic dishes and weighed. The samples were then left, exposed to the relatively dry air in the laboratory. The samples were periodically re-weighed to determine the mass loss with respect to time.

\subsubsection{Test Results and Discussion}

Evaporation test results are presented in Table 7. In all cases, approximately two-thirds of the total mass loss occurred over the first two days of exposure to the environment. Generally, mass loss results were as expected, although a few surprises did result.

The baseline formulation sample CsOpt 1 exhibited one of the highest mass fraction loss to evaporation. Based on the analysis of the original quicklime, showing that it actually consists mainly of $\mathrm{Ca}(\mathrm{OH})_{2}$, the sample CsOpt 7 had essentially the same formulation as the baseline. The near identical evaporation mass fraction loss of the two samples, thus, is exactly what is expected.

As compared with the baseline formulation, the slight reduction in the $\mathrm{CaO}$ mass fraction and equivalent increase in OPC and BFS mass fractions ( $\mathrm{CsOpt} 4$ ), resulted in a slight improvement (increase in water retention). Further similar $\mathrm{CaO}$ substitution ( $\mathrm{CsOpt} 3$ ) showed a return to the higher mass fraction evaporation loss.

Substitution of $\mathrm{CaO}$ with $\mathrm{NaOH}$ increases water retention (CsOpt 2 and 8). In fact, the sample having by far the least evaporation mass loss also had the highest fraction of $\mathrm{CaO}$ substituted with $\mathrm{NaOH}$ (CsOpt 8). However, just a small further increase in $\mathrm{CaO}$-to-NaOH substitution (CsOpt 17) results in 
unacceptable free liquid on the final waste form. $\mathrm{CaO}$ substitution with $\mathrm{MgO}$ seemingly has little effect on the extent of evaporation.

As expected, the use of $\mathrm{CaO}\left(\mathrm{CsOpt} 10\right.$ and 11) has significant advantage over $\mathrm{Ca}(\mathrm{OH})_{2}$ with respect to minimizing evaporation. Even at increased waste loadings (CsOpt 12, 13, 14, and 15) total sample mass fraction losses are significantly reduced, as compared to other formulations using $\mathrm{Ca}(\mathrm{OH})_{2}$ (including the original "old" $\mathrm{CaO}$ ).

Table 7. CsIX Grout Sample Water Loss by Evaporation

\begin{tabular}{|c|c|c|c|}
\hline & \multicolumn{2}{|c|}{ Grout Sample Mass (grams) } & Total Sample Mass \\
Loss (\%)
\end{tabular}

\subsection{Thermal Cycle Testing}

Closely related to the evaporation issue, concern has been expressed about the potential of free liquid appearing in the waste drums during interim storage as a result of thermal cycling. Thermal cycling of grout samples is typically done to determine the integrity of a formulation as measured by change in compressive strength. In this case, thermal cycling was performed to determine if the release and accumulation of free liquid in the waste drums, as a result of thermal cycling during interim storage, is a valid concern. 


\subsubsection{Test Description}

Thermal cycle testing was conducted only with samples of formulations CsOpt 1, 2, 3, 4, and 6 . Grout samples were prepared and cured in sealed containers to prevent any liquid from escaping due to evaporation. Initially, 250 gram samples were mixed and poured into glass jars. The jars were sealed, allowed to cure for 30 days, and then subjected to thermal cycling in a Tenney Environmental Chamber. The thermal cycling consisted of thirty 7-hour cycles. Each cycle consisted of 2 hours at $60^{\circ} \mathrm{C}$, followed by 1 hour at $20^{\circ} \mathrm{C}$, followed by 2 hours at $-40^{\circ} \mathrm{C}$, followed by 1 hour at $20^{\circ} \mathrm{C}$. Each change in temperature had a 15-minute period for the change to occur. Following the thermal cycling, the samples were removed from the environmental chamber, and inspected for obvious degradation and/or the presence of free liquid. Three of the five jars had broken (CsOpt 1,2, and 4) during the thermal cycling, invalidating any test results. For the two sample jars that had not broken (CsOpt 3 and 6), no sign of liquid was present in either. Although no strength test was performed on the contained samples, they were both quite hard to the touch, with no detectable degradation of the monolith.

Because of the breaking of the glass sample containers, the test was repeated using plastic jars. The same formulation 250 gram samples were mixed and poured into plastic jars. The jars were again sealed, weighed, allowed to cure for 30 days, and then subjected to the thermal cycling, identical to the previous testing described above. Following the thermal cycling, the samples were removed from the environmental chamber, re-weighed, and inspected for obvious degradation and/or the presence of free liquid.

\subsubsection{Test Results and Discussion}

Following the thermal cycles, each of five test samples had exactly the same mass as the day it was originally mixed and sealed. Opening the plastic jars and inspecting the samples showed each to be hard and monolithic, with no apparent physical change. Absolutely no sign of free liquid was present in any of the plastic jars.

Although evaporation and condensation of non-chemically bound water as a result of thermal cycling is a reasonable concern, it is apparent that for the grouts tested, any condensate that may have been produced in the sealed jars was re-adsorbed into the grout solid.

\subsection{Conclusions}

As a result of this CsIX grout formulation optimization testing, several conclusions can be made:

1. The viscosity of the baseline CsIX grout formulation can be significantly improved (lowered) by making any of several minor formulation modifications. These modifications all involve a relatively small reduction in $\mathrm{CaO}$ content, by either substitution or direct reduction. Although excess $\mathrm{CaO}$ is the key to the high waste loading capabilities of this grout formulation, limits of that chemical do exist with respect to processability.

2. Although partial substitution of $\mathrm{CaO}$ with either $\mathrm{MgO}$ or $\mathrm{NaOH}$ can significantly improve the baseline formulation viscosity, other aspects of the grout products prohibit a recommendation for any such substitution. $\mathrm{CaO}$ substitution with $\mathrm{NaOH}$ decreases mass loss via evaporation, but also proves to result in decreased compressive strengths. Additionally, this substitution has potential for an actual significant increase in mixture viscosity, particularly if mixture cooling is performed following acid neutralization. Partial $\mathrm{CaO}$ substitution with $\mathrm{MgO}$ could also result in increased mixture viscosity. All CsIX grout formulations involving acid neutralization with either $\mathrm{MgO}$ or $\mathrm{NaOH}$ will require significant further investigation to explain the dramatic viscosity increases 
experienced in unique cases of this testing.

3. A SBW waste loading of $70 \mathrm{wt} \%$ is easily within the capabilities of several of the grout formulations tested. Some tolerance for waste loading variation will definitely be available.

4. Concerns over free liquid appearing in waste drums filled with these grouts, as a result of thermal cycling, appear to be invalid. Although some condensate may be generated during thermal cycling, it is apparently re-adsorbed into the grout monolith. Furthermore, no apparent physical degradation of the grout is evident as a result of thermal cycling.

5. From the original CsIX baseline grout formulation, waste form mass loss via evaporation can be significantly reduced through the use of $\mathrm{CaO}$ instead of $\mathrm{Ca}(\mathrm{OH})_{2}$, or by substituting a significant fraction of the $\mathrm{CaO}$ (or $\mathrm{Ca}(\mathrm{OH})_{2}$ ) used with $\mathrm{NaOH}$.

\subsection{Recommendations and Discussion}

Based on the CsIX grout development and optimization test results, to date, the recommended baseline formulation has been modified to:

$70 \mathrm{wt} \%$ CsIX sodium-bearing waste,

9 wt $\%$ Calcium Oxide,

$7 \mathrm{wt} \%$ Ordinary Portland Cement, and

$14 \mathrm{wt} \%$ Blast Furnace Slag.

This new baseline formulation does not exactly represent any of the formulations prepared in this testing, but is an extrapolation of results. It is most closely represented by formulation CsOpt 20. This formulation has an approximately $18 \%$ reduction in $\mathrm{CaO}$ from the original baseline, but still retains substantial excess $\mathrm{Ca}(\mathrm{OH})_{2}$ after initial neutralization and other reactions. This reduction in $\mathrm{CaO}$ will significantly reduce the viscosity of the grout mixture, vastly improving processability. Also from the original baseline formulation, OPC is unchanged, while BFS is significantly increased. This increase is made because of the negligible impact BFS has on the viscosity of the mixture, while still offering other beneficial ingredients: 1) sulfide for toxic element immobilization, and 2) slow-reacting pozzolans for eventual waste form strength.

\subsection{Future Testing}

Although the optimization testing performed to date has resulted in significant physical improvement to the CsIX waste form, considerable additional work is required. Of immediate concern is verification testing of the new formulation. Duplicate physical (i.e. compressive strength) and chemical (i.e. TCLP leach) tests will be performed. Some minor formulation changes could still result.

Further testing will be required to determine the concentration limits of individual CsIX waste components with respect to the waste form physical and chemical properties. Testing will be required to determine which waste component changes will require alterations in the grout formulation, and what those formulation alterations consist of.

Additional similarly testing will be required to determine the tolerances of the grout formulation to variations in quantities of individual grout components (and waste solution) used. 


\section{AUTOMATED GROUT MIXER TEST}

On July 6 and 7, 2000, the Readco test facility located in York, PA was visited and various grout mixing tests were observed. Readco is a manufacturer of continuous process mixers which utilize a twin screw design. A 2-inch mixer was utilized to mix grout powders with simulated cesium ion-exchange sodium bearing waste (CsIX) following neutralization. Irvin Snider, manager of Readco Processing and Mixing Equipment, was our primary contact. Also present were: David Carroccia of Raytheon, Jay Pride of Scientific Technology, Andy Bickers of Perkinson, and Alan Herbst of Bechtel BWXT. Jay Pride was contracted by DES MetalPlex to test their clay grouts and Andy Bickers is a Readco sales engineer from Knoxville. The photographs included with this report were provided by David Carroccia.

\subsection{Test Description}

Two 55-gallon drums of prepared simulant that had been neutralized to about a $\mathrm{pH}$ of 7 were brought for testing by Jay Pride. Each drum contained 270 pounds of CsIX simulant which filled the drum about $1 / 2$ to $3 / 4$ full. To one drum, 34 pounds of calcium oxide $(\mathrm{CaO})$ had been added resulting in an extremely thick sludge (see Figure 2, page 19). To the second drum, 29 pounds of calcium oxide had been added yielding a more flowable sludge. The change in fluid properties was very noticeable with a difference of only 5 pounds of calcium oxide. To pump the first drum a gear pump was used which had to be force primed and low pressure air was used to pressurize the drum to establish flow. The second drum was more flowable and did not require priming or pressure.

Figure 3 shows the mixer set up. Readco's 2-inch continuous mixer was utilized for the tests. The grout powders (clay or cement/slag) and the remaining calcium oxide were added simultaneously from the gravimetric feeders (the grout powders from the left in the photograph and the calcium oxide from the right). The grout powders were premixed for the individual tests. The overall production rate of the Readco mixer could be varied from 100 to 900 pounds per hour (\#/hr). Additionally the mixer blade speed could be varied from 100 to 300 revolutions per minute (rpm). The solids were added at the headend of the mixer and the simulated liquid waste was injected just downstream of the solids addition chute. The mixture traveled about 12 more inches and discharged out of the bottom of the mixer. The internal mixer blades can be arranged as needed for mixing, blending, and pushing; such set ups are considered proprietary.

The initial MetalPlex test utilized the following mixture: Simulant $-70 \%$, calcium oxide $-11 \%$, and MetalPlex clays with proprietary additive $-19 \%$ by weight. Jay Pride varied this mixture over the 2 days of tests as well as production rate. The Idaho grout formulation contained: Simulant $-70 \%$, calcium oxide $-11 \%$, blast furnace slag $-11 \%$, and ordinary portland cement $-8 \%(\mathrm{OPC})$. This latter blend was not changed during the mixing tests; however the production rate was varied from $100 \# / \mathrm{hr}$ to $900 \mathrm{H} / \mathrm{hr}$.

\subsection{Test Results}

The Readco processor is very capable of blending the liquid sludge and dry powders to produce a homogenous mix. The residence time in the mixer is less than one minute. The initial MetalPlex test with the first drum produced a viscous product such as noted in Figure 4. The Idaho grout formulation was somewhat less viscous with a conical pile such as in Figure 5.

Numerous small samples ( 2 inch diameter by 4 inch high cylinders) and several large batch samples in 5 gallon pales (Figure 5) were taken. As mentioned the residence time in the mixer is short and it was noted that while holding the small samples for labeling, the sample temperature perceptually 
raised to the touch; thus indicating that the chemical reactions were not all occurring in the mixer, but later in the container. Five small samples, 3 with MetalPlex (MP) and 2 with Idaho grout (ID), were brought to INEEL for testing (see Table 8). All other samples are to be sent to DES MetalPlex.

Table 8. Samples Taken for Testing at INEEL

\begin{tabular}{|l|c|c|c|c|c|c|c|c|}
\hline Sample & $\begin{array}{c}\text { Readco } \\
\text { Run \# }\end{array}$ & $\begin{array}{c}\text { CsIX } \\
\text { Drum \# }\end{array}$ & $\begin{array}{c}\text { CsIX } \\
\text { Sim. } \\
(\mathbf{l b} / \mathbf{m i n})\end{array}$ & $\begin{array}{c}\text { Added } \\
\mathbf{C a O} \\
(\mathbf{l b} / \mathbf{m i n})\end{array}$ & $\begin{array}{c}\text { MtPx } \\
\text { Clays } \\
(\mathbf{l b} / \mathbf{m i n})\end{array}$ & $\begin{array}{c}\text { Slag / } \\
\text { OPC } \\
(\mathbf{l b} / \mathbf{m i n})\end{array}$ & $\begin{array}{c}\text { Produc } \\
\text { t Rate } \\
(\# / \mathbf{h r})\end{array}$ & $\begin{array}{c}\text { Mixer } \\
\text { Speed } \\
(\mathbf{r p m})\end{array}$ \\
\hline MP-1 & 1 & 1 & 1.311 & 0.037 & 0.319 & & 100 & 100 \\
\hline MP-2 & 3 & 1 & 1.311 & 0 & 0.319 & & 100 & 200 \\
\hline MP-3 & 12 & 2 & 6.500 & 0.278 & 1.558 & & 500 & 300 \\
\hline ID-1 & 9 & 2 & 1.300 & 0.056 & & 0.312 & 100 & 200 \\
\hline ID-2 & 11 & 2 & 11.700 & 0.500 & & 2.805 & 900 & 300 \\
\hline
\end{tabular}

As noted, the mixer produces a homogeneous grout; however, there was one time when the mixer lost liquid feed. The problem was immediately noted by the horsepower monitor as the mixer required considerably more power to turn the solids. Figure 6 shows the results of the loss of liquid feed.

Following the mixing tests, the discharge valve was closed and about 1 quart of water was poured into the mixer to clean the mixer. At this point it was noted that the shaft seals leaked considerably at the headend. The seals between the upper and lower shells worked fine along the straight edges, but a small amount leaked at the 90 degree corners where the seal was not continuous. Following a second rinse, the upper shell was opened showing that most of the grout was cleaned from the mixer; however some grout remained on the screw blades near the discharge (see Figure 7). No grout mixture leaked from the seals due to its viscous nature; however, there was solid build up around the edges of the discharge chute (see Figure 8).

During the 28 day curing period, the samples were left in the original plastic sample vials. After which the plastic vials were removed and the samples were placed in locking type plastic bags. The Idaho samples had set up; however, the MetalPlex samples were still soft to the touch and had not set up during the cure period. Two samples were compression test immediately after the cure period and two samples were thermal cycled. The thermal cycle test consisted of 30 cycles from $+60^{\circ}$ to $-40^{\circ} \mathrm{C}$. The compressive strength results are noted in Table 9.

Table 9. Mixer Test Sample Compressive Strength Results

\begin{tabular}{|c|c|c|}
\hline \multicolumn{3}{|c|}{ Initial Compression Testing: } \\
\hline Sample & Density (g/cm $\left.{ }^{3}\right)$ & $\begin{array}{c}\text { Compressive } \\
\text { Strength (psi) }\end{array}$ \\
\hline MP-1 & 1.48 & 30 \\
\hline ID-1 & 1.49 & 590 \\
\hline \multicolumn{3}{|c|}{ Following 30 Thermal Cycles } \\
\hline MP-3 & 1.51 & 0 \\
\hline ID-2 & 1.50 & 260 \\
\hline
\end{tabular}


Sample MP-3 just smashed with no resistance in the automatic compression test mode. The machine was switched to manual mode and run at full displacement speed. MP-3 sample was deformed about 1 inch and the maximum resistance force was 33.7 pounds for $10 \mathrm{psi}$.

To check for moisture loss from the samples (refer to Section 2.4), the residues from MP-1 and ID-1 were left open to the atmosphere at ambient temperature and pressure. The mass was taken after 1, 2, and 6 weeks. The results are noted in Table 10. Both samples lost about the same mass. Following this drying period, the MP-1 sample was firm to the touch; however, it had noticeably shrunk in size from $50 \mathrm{~mm}$ to $44 \mathrm{~mm}$ diameter. ID-1 showed not signs of dimensional changes. (Due to the compression test, no length dimensions are available.)

Table 10. Sample Mass Loss to Atmosphere

\begin{tabular}{|c|c|c|c|c|c|}
\hline Sample & Initial Mass & 1 Week Loss & 2 Week Loss & 6 Week Loss & Total \% Lost \\
\hline MP-1 & $287.9 \mathrm{~g}$ & $35.2 \mathrm{~g}$ & $74.9 \mathrm{~g}$ & $94.4 \mathrm{~g}$ & $31.8 \%$ \\
\hline ID-1 & $286.2 \mathrm{~g}$ & $31.0 \mathrm{~g}$ & $68.8 \mathrm{~g}$ & $101.3 \mathrm{~g}$ & $34.4 \%$ \\
\hline
\end{tabular}

\subsection{Overall Results and Concerns}

Listed below are some positive results and concerns noted from the Readco mixer tests.

\subsubsection{Positive Results:}

1. The Readco continuous mixer produces a homogeneous grout mixture.

2. The mixer can handle a wide range of grout formulations and fluid properties.

3. Readco produces mixers that can handle our projected feed rates.

\subsubsection{Concerns:}

1. When placed in radioactive use, the mixer seals may be a source of contamination leaking from the machine, especially the shaft seals. Solid contamination may build up around the discharge chute. This may be worked out with proper seals and discharge design.

2. Radioactive fields around the mixer may increase due to build up of grout on the mixer blades that can not be rinsed off.

3. Additional instrumentation will be required to control the continuous mixer. All feed lines would need to be controlled and recorded to document proper mix for waste acceptance. The case of loss in liquid feed would produce an off-spec. grouted waste that would need special handling or rework to meet disposal criteria. In the case of the loss on one feed all others would need to be shut off immediately to prevent off-spec. grouts.

4. Due to the short residence time in the mixer, some chemical reactions may not complete internal to the mixer. This should not be a problem for cement hydration reactions, but would be a problem if neutralization is needed prior to cement addition. This may be worked out with proper injection points in the machine. 
5. It is thought the external mixing may be able to fill the drum closer to the lid. However, with the grouts noted in this test, considerable void space may be created as the extruded grout piles up and folds on itself or forms a stalagmite from the bottom up. A more self-leveling grout would be needed for external mixing and pouring to a drum; however, this is extremely difficult to do while avoiding bleed water with the CsIX type waste at such waste loadings.

6. The fresh calcium oxide used to neutralize the simulant produced a thick sludge that is difficult to pump. The neutralization step needs further development to yield a operable and reliable process. Utilizing calcium hydroxide and $\mathrm{pH}$ control may solve this concern.

7. The MetalPlex clay grout formulation did not provide any benefit over the Idaho grout formulation. The clay samples did not set up and did not improve the moisture mass loss.

Figure 2. Neutralized Simulated CsIX Sodium Bearing Waste, 270 Pounds Of Simulant Mixed With 34 Pounds Of Calcium Oxide.

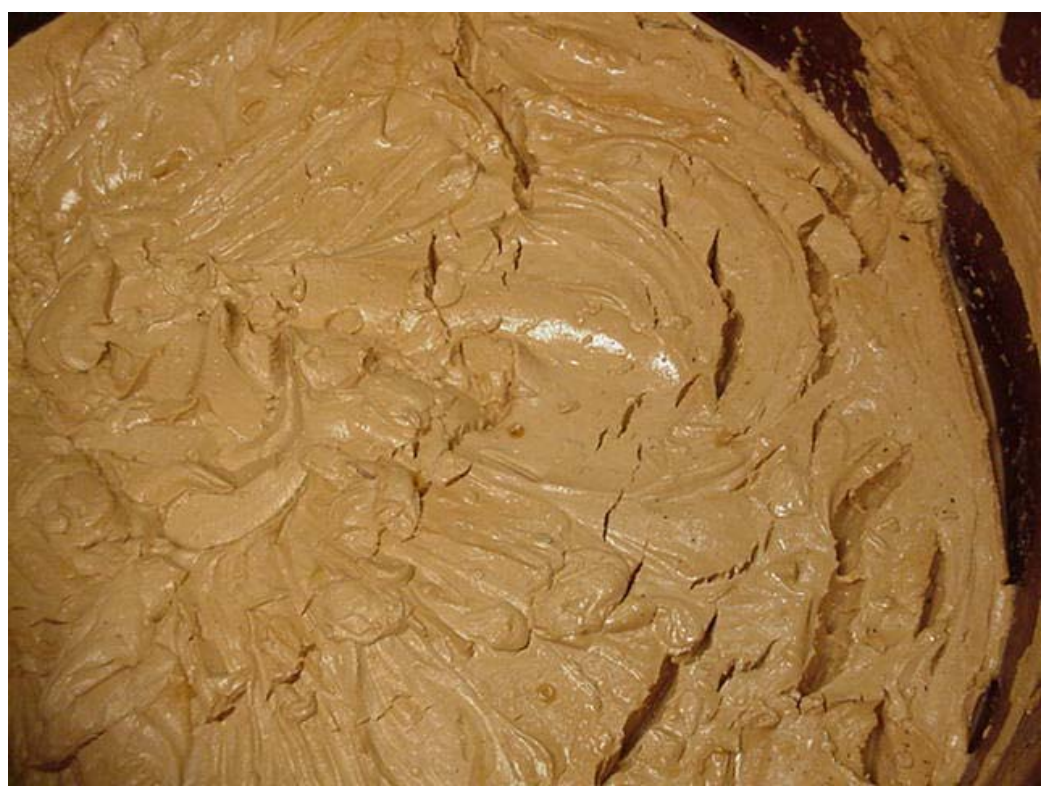


Figure 3. Readco Test Equipment Showing 2-Inch Mixer (Center) With Two Gravimetric Solid Feeders (Right and Left) And The Liquid Feed Pump (Lower Right).

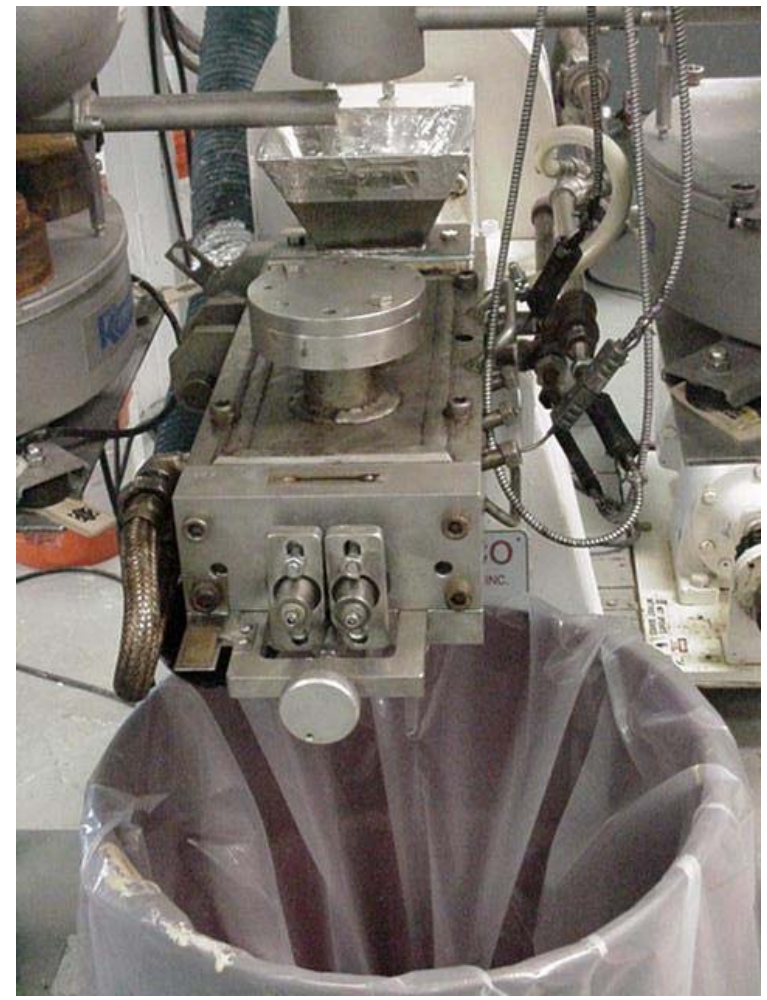

Figure 4. Example Of Initial MetalPlex Test Product.

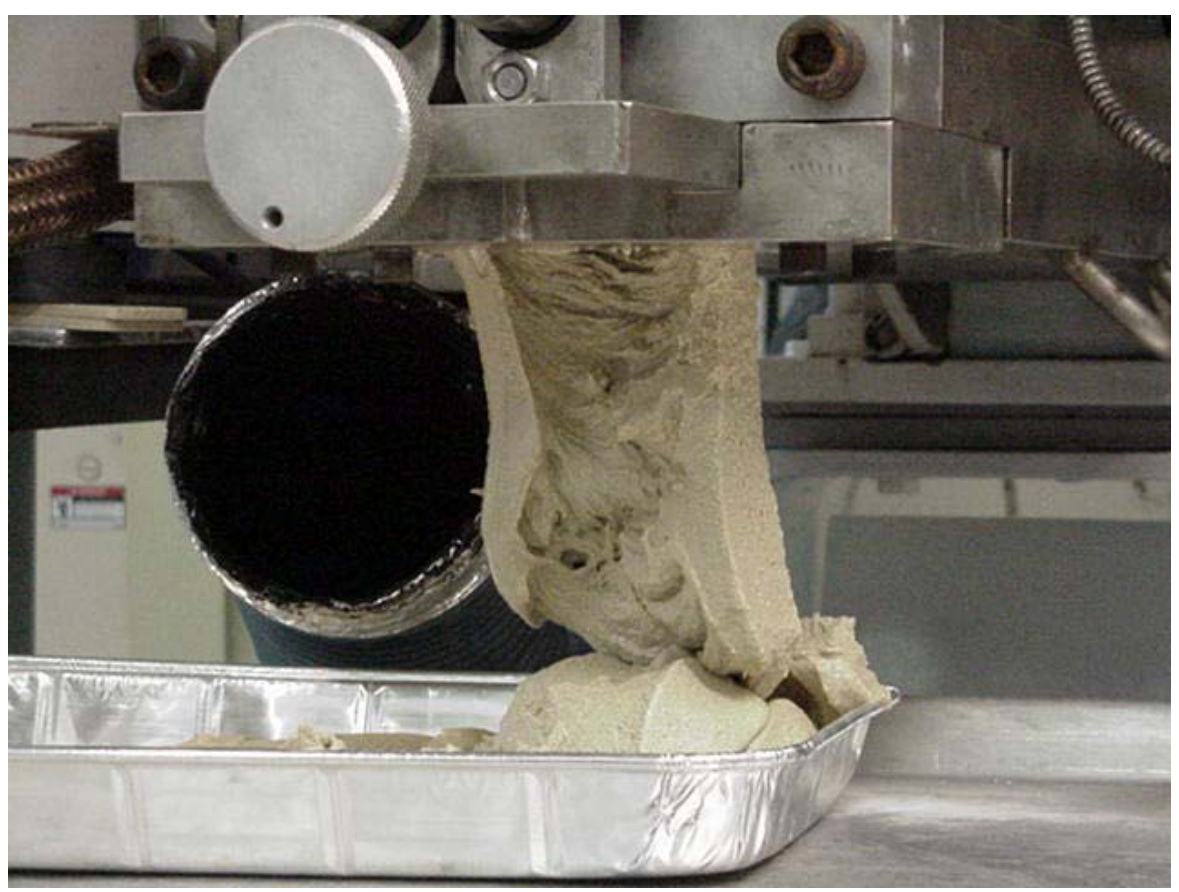


Figure 5. Example Of Idaho Grout Formulation Product.

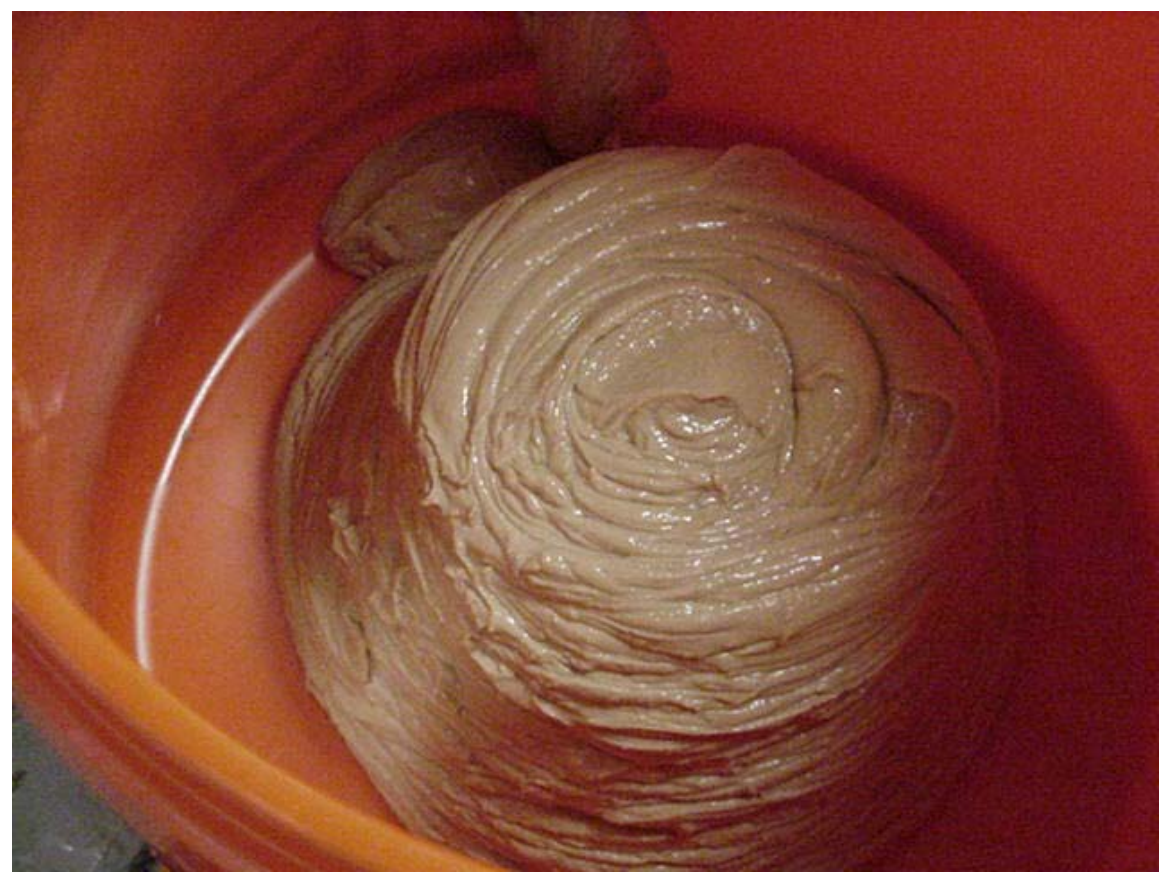

Figure 6. Results Of The Loss Of Liquid Feed To The Mixer.

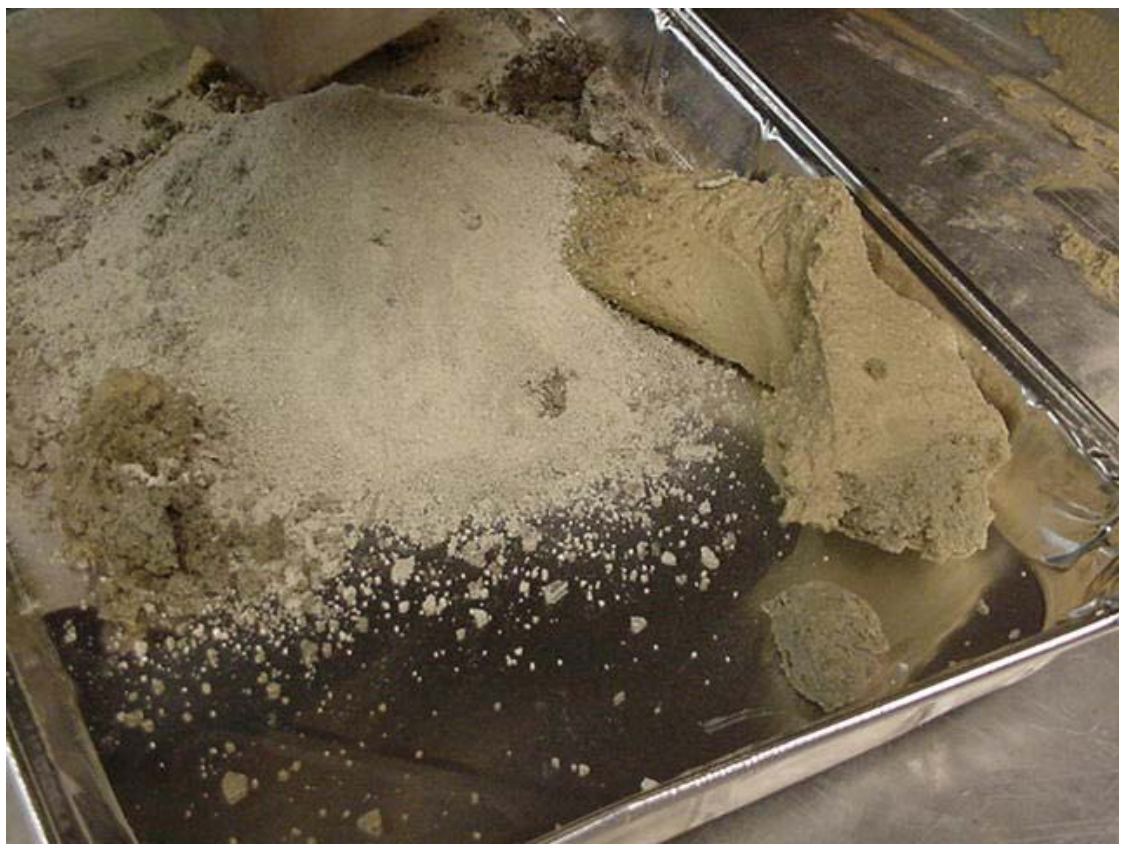


Figure 7. Internal View Of The Readco Mixer Following Two Rinses.

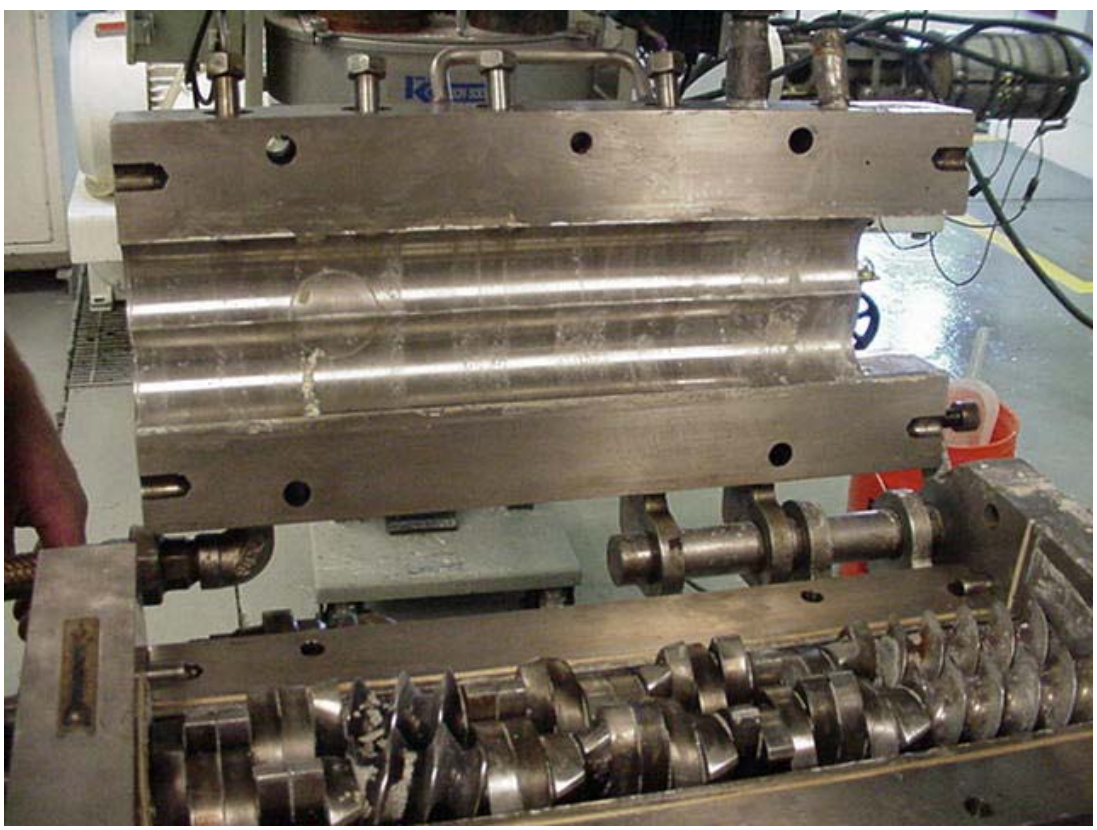

Figure 8. Discharge Chute From The Mixer.

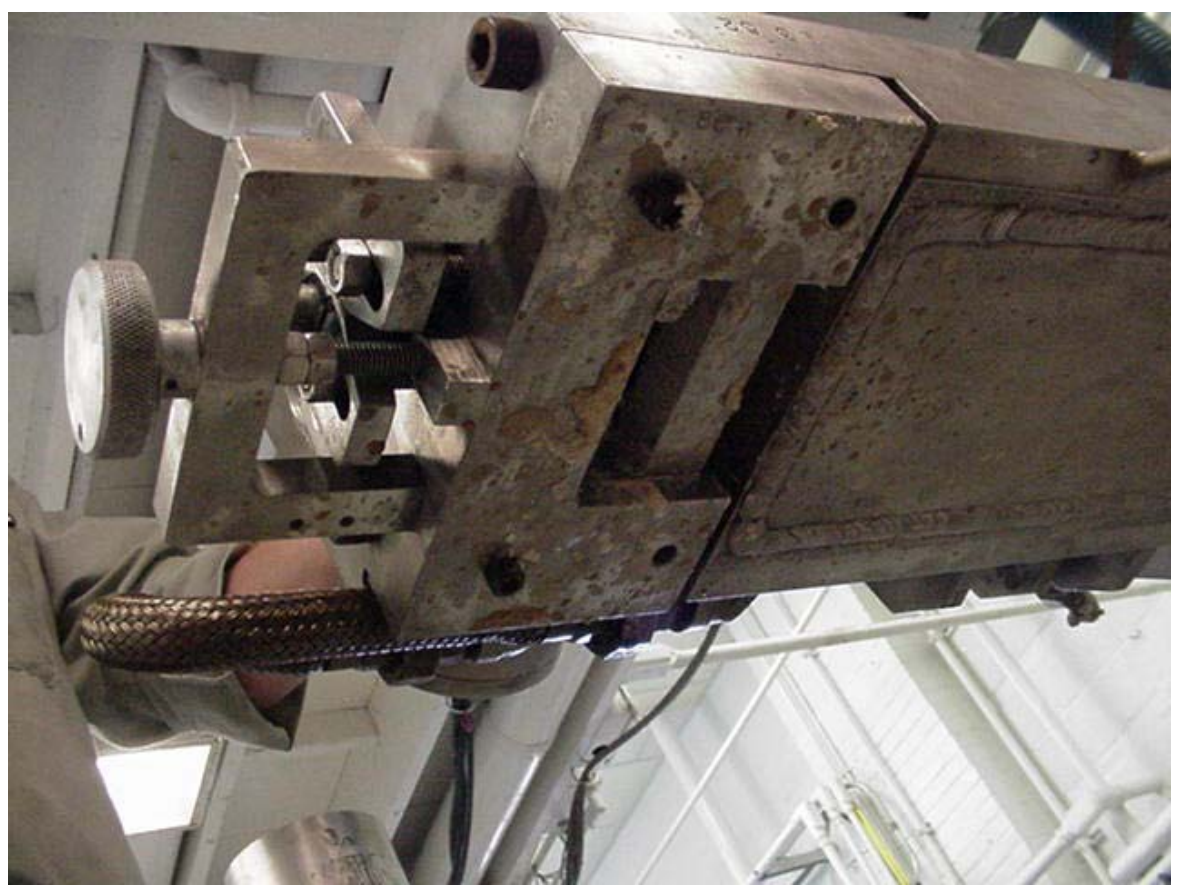




\section{NGLW GROUT DEVELOPMENT}

As detailed in the feasibility study for the newly generated liquid waste demonstration project, the High-Level Liquid Waste Evaporator (HLLWE) will be used to reduce the tank farm inventory. The HLLWE bottom solution will be returned to the tank farm and the overhead condensate stream will be sent to the Process Equipment Waste Evaporator (PEWE) for further concentration. It was proposed to combine this condensate stream with CPP-603 pool water to control nitrate and chloride content (see Figure 9). The PEWE overhead condensate would be sent to Liquid Effluent Treatment and Disposal facility (LET\&D) and the bottom solution would be sent for low-level waste grouting rather than back to the tank farm. Initially, the combined solutions would be reduced by 500 to 1, i.e. 500 parts condensate to LET\&D and 1 part bottom solution to grouting. However, it was found that at this concentration, the resulting waste form would not meet Envirocare waste acceptance criteria for radioactive cesium and strontium. The feasibility study determined that if the combined solution were only evaporated to a concentration of 31 times rather than 500, the waste form would meet Envirocare waste acceptance criteria. Therefore, the dilute solution was briefly studied to determine a grout formulation and whether the PEWE could operate to produce the needed waste concentration.

Figure 9. 50 Day Batch Flow Diagram for Newly Generated Liquid Waste

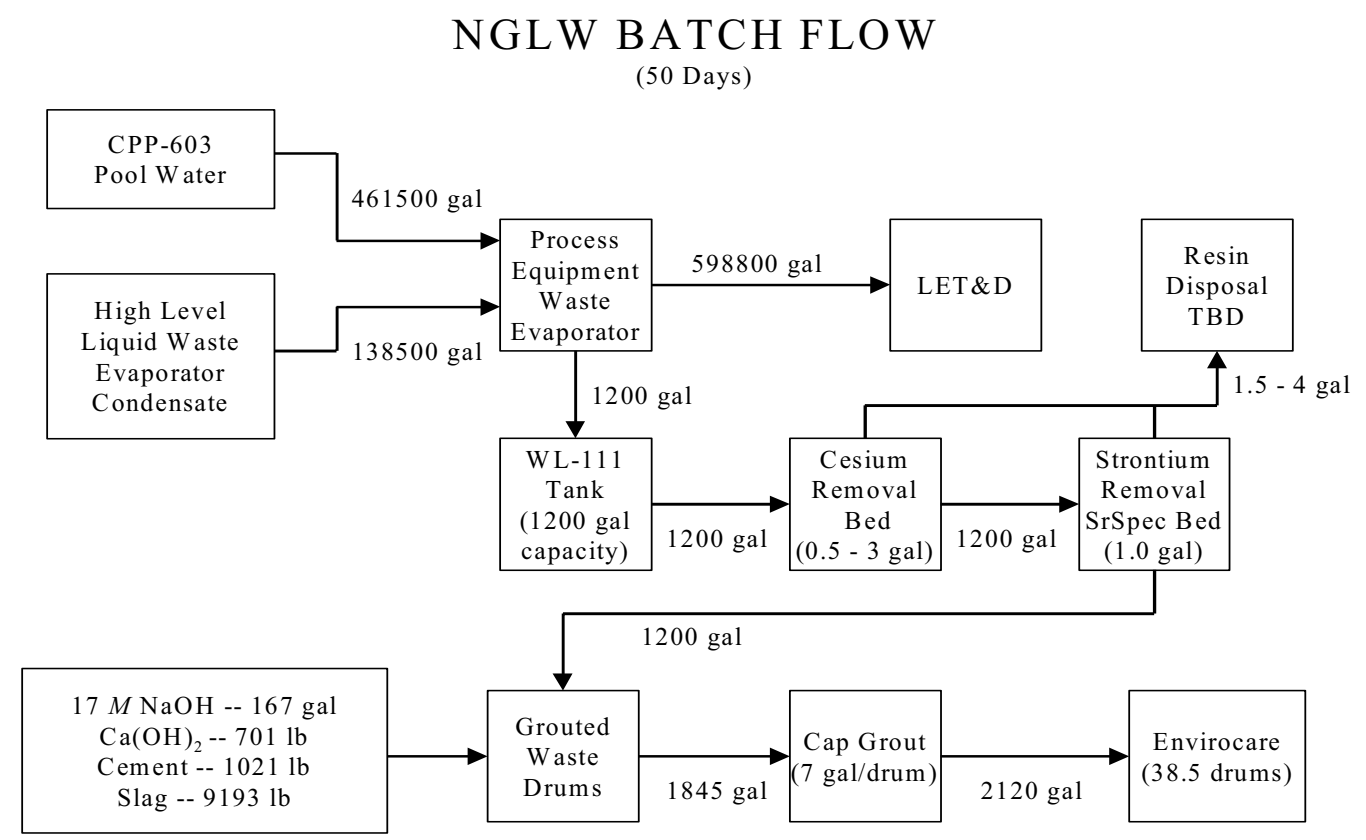

\subsection{Revised NGLW Grout Formulation}

Both at AEA Technologies and at INTEC, the dilute solution was test grouted with the same formulation and waste loading as found for the 500:1 solution. In both case it was found that bleed water 
developed at the $45 \mathrm{wt} \%$ to $50 \mathrm{wt} \%$ waste loadings. Therefore, the waste loadings was reduced to avoid free standing liquid. AEA testing noted that free liquid or bleed water developed at $40 \mathrm{wt} \%$ and $35 \mathrm{wt} \%$ and recommended grouting at $25 \mathrm{wt} \%$ to $30 \mathrm{wt} \%$. The experiment was repeated at INTEC using U.S. supplied cement powders and found that bleed water also developed at $40 \mathrm{wt} \%$, but that the $35 \mathrm{wt} \%$ formulation was acceptable as well as the $30 \mathrm{wt} \%$ batch. The $25 \mathrm{wt} \%$ batch was extremely thick and difficult to mix due to high viscosity. Getting to the lower waste loadings may require adjustment of the formulation to include some water to control the viscosity, but need to be careful to avoid bleed water. At the $25 \mathrm{wt} \%$ to $35 \mathrm{wt} \%$ formulations, the waste forms set up and will meet the Envirocare waste acceptance criteria. As mentioned, the no free liquids criteria is the critical item since there are no physical strength requirements.

\subsection{NGLW Evaporation and Neutralization Study}

\subsubsection{Test Operation}

The laboratory scale evaporation was performed in a 4-liter beaker heated with a hot plate. The tests were conducted by evaporating the solution incrementally. A total of 16 liters of the simulated NGLW solution were prepared (Table 11). For initial evaporation, the feed solution (in 3.5 or 2 liters batch) was boiled until about 75 percent of the liquid had been evaporated. The combined concentrate solutions from the initial evaporations were evaporated further until the boildown ratio of approximate 31:1 (from the initial feed) was achieved. After the solution cooled down, the liquid volume was measured and its specific gravity determined. The feed solution and the concentrate were collected for analysis. The compositions of the anticipated NGLW feed and the test feeds are compared in Table 1.

To accommodate high $\mathrm{pH}$ requirement $(\mathrm{pH}>11)$ for grout formulation, the addition of concentrated solution to base $(50 \% \mathrm{NaOH})$ rather than adding base to the concentrate was studied. The reverse addition could avoid the $\mathrm{pH}$ ranges that form thick sludges while allowing higher $\mathrm{pH}$ values to be achieved. For each reverse addition test, the concentrate solutions from the test above were slowly introduced into approximate $10 \mathrm{ml} 50 \% \mathrm{NaOH}$ solution. The titration was terminated after the mixture's $\mathrm{pH}$ reached ranges of 9-10.

Table 11. NGLW Compositions

\begin{tabular}{|c|c|c|c|}
\hline Species & Feed Estimated $(\underline{\boldsymbol{M}})$ & Feed Tested $(\underline{\boldsymbol{M}})$ & Concentrate $(\underline{\boldsymbol{M}})^{*}$ \\
\hline $\mathrm{H}^{+}$ & $8.00 \mathrm{E}-2$ & $7.74 \mathrm{E}-2$ & $2.28 \mathrm{E}+0$ \\
\hline $\mathrm{Al}^{+3}$ & $3.50 \mathrm{E}-4$ & $3.33 \mathrm{E}-4$ & $9.89 \mathrm{E}-3$ \\
\hline $\mathrm{Ca}^{+2}$ & $2.80 \mathrm{E}-4$ & $2.47 \mathrm{E}-4$ & $7.13 \mathrm{E}-3$ \\
\hline $\mathrm{K}^{+}$ & $6.00 \mathrm{E}-5$ & $8.24 \mathrm{E}-5$ & $2.37 \mathrm{E}-3$ \\
\hline $\mathrm{Na}^{+}$ & $3.33 \mathrm{E}-3$ & $2.93 \mathrm{E}-3$ & $8.60 \mathrm{E}-2$ \\
\hline $\mathrm{Cl}^{-}$ & $2.90 \mathrm{E}-3$ & $2.93 \mathrm{E}-3$ & $7.96 \mathrm{E}-2$ \\
\hline $\mathrm{F}^{-}$ & $1.30 \mathrm{E}-4$ & $1.32 \mathrm{E}-4$ & $2.06 \mathrm{E}-3$ \\
\hline $\mathrm{NO}_{3}^{-}$ & $8.00 \mathrm{E}-2$ & $7.85 \mathrm{E}-2$ & $2.32 \mathrm{E}+0$ \\
\hline $\mathrm{SO}_{4}^{-2}$ & $1.60 \mathrm{E}-4$ & $1.85 \mathrm{E}-4$ & $7.04 \mathrm{E}-3$ \\
\hline $\mathrm{Sp} . \mathrm{G}$ & ---- & 1.011 & 1.086 \\
\hline
\end{tabular}

* Solution at the boildown ration of 30.8 


\subsubsection{Results and Discussion}

After the evaporation test, a total of $520 \mathrm{ml}$ concentrate was collected from the initial feed of 16 liters solution, at the estimated boildown ratio of approximate 30.8:1. The concentrate compositions are listed in Table 11. The density of the cooled concentrate is used in place of the boiling point density because the density could only be measured in the cooled solution. There has no precipitation in the concentrate, and portions of chloride and fluoride were volatile during evaporation.

For base reverse addition test, two tests were performed with similar results. The test results are shown in Figures 10 and 11. By adding 78-79ml of the concentrate to approximate $10 \mathrm{ml} 50 \% \mathrm{NaOH}$ solution $\left(\rho=1.525 \mathrm{~g} / \mathrm{ml} @ 20^{\circ} \mathrm{C}\right)$, the solution mixture would stabilize at $\mathrm{pH}$ of around 12 . Some precipitates were formed at the $\mathrm{pH}$ of 12 . Further addition of the concentrate to the mixture could resulting a significant decrease of the solution $\mathrm{pH}$, as indicated in both Figures 10 and 11. A precision control of mixing and $\mathrm{pH}$ monitoring will be very crucial to maximize waste loading with acceptable mixture $\mathrm{pH}$ for grout formulation.

Figure 10. NGLW Concentrate Reverse Addition Curve (15.48 g 50\% NaOH)

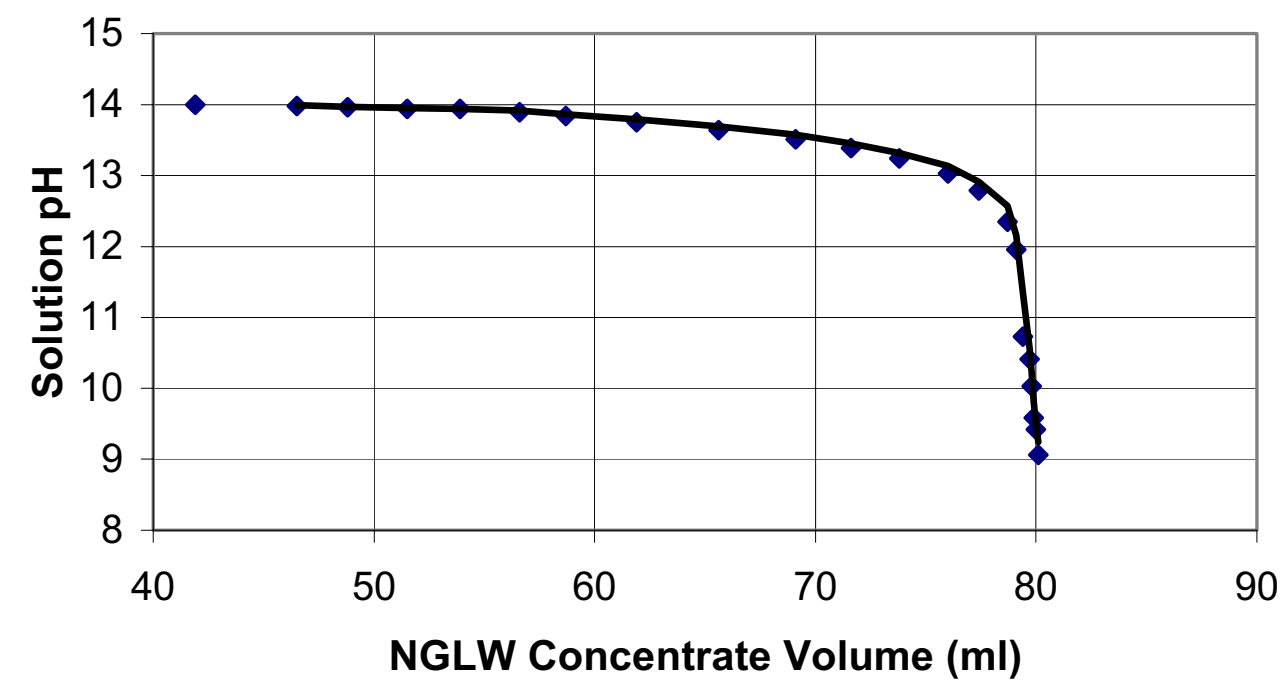


Figure 11. NGLW Concentrate Reverse Addition Curve (15.51 g 50\% NaOH)

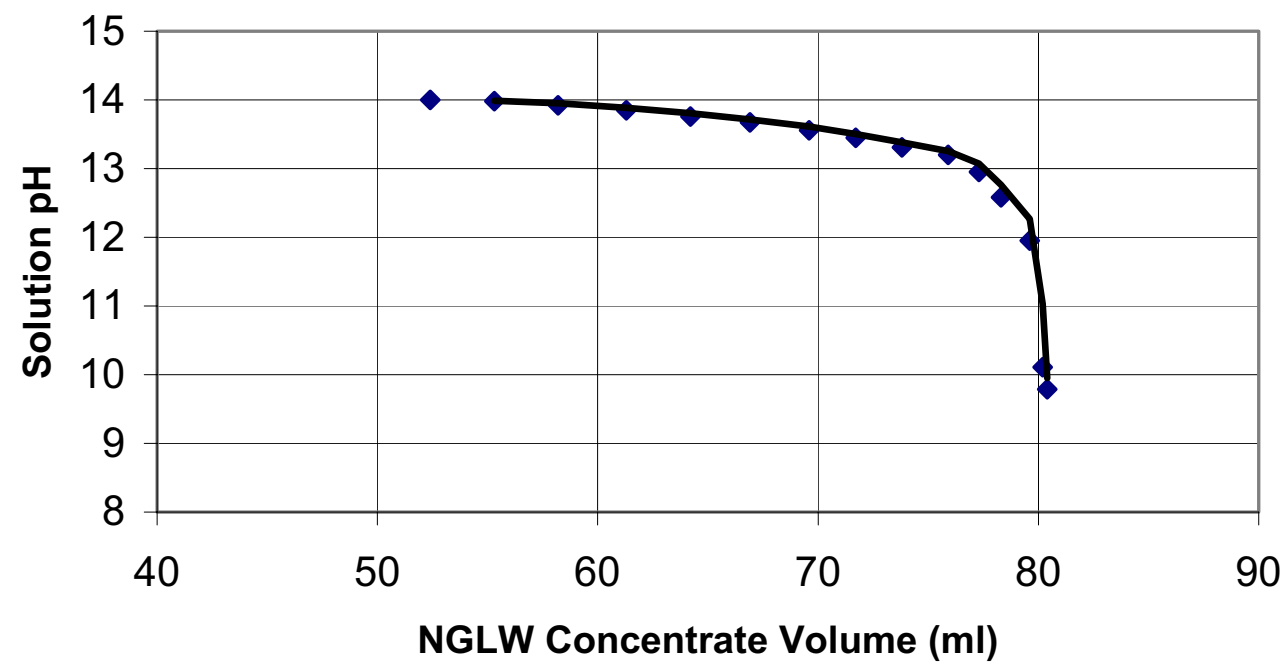

\subsection{Mercury Retention in NGLW Grout}

A short scoping study was completed to determine the NGLW grout formulation's ability to retain mercury. The projected concentrations ${ }^{6}$ vary from 10 to $5000 \mathrm{mg} / \mathrm{L}$ in the NGLW. It was determined that the NGLW grout formulation will pass TCLP. The grout formulation used in each of the 12 test grouts were as shown in Table 12 . The simulant density was $1200 \mathrm{~g} / \mathrm{L}$ and the grout density was $1600 \mathrm{~g} / \mathrm{L}$. The analytical purity of the mercury nitrate was calculated to be $88 \%$ from simulant analysis.

Table 12. Grout Formulation for NGLW Mercury Tests

\begin{tabular}{|l|c|c|}
\hline Component & $\begin{array}{l}\text { Mass Used per } \\
\text { Batch (g) }\end{array}$ & Weight Percent \\
\hline NGLW Waste Simulant & 113.0 & 45.0 \\
\hline Sodium Hydroxide 50\% Solution & 18.4 & 7.4 \\
\hline Calcium Hydroxide & 6.6 & 2.6 \\
\hline Blast Furnace Slag & 101.7 & 40.5 \\
\hline Portland Cement & 11.3 & 4.5 \\
\hline
\end{tabular}

As noted from Table 13, the mercury in the grouted simulant varied from 500 to over $5000 \mathrm{mg} / \mathrm{L}$. The highest TCLP value was $0.001 \mathrm{mg} / \mathrm{L}$ and the treatment standard for mercury is $0.025 \mathrm{mg} / \mathrm{L}$. Thus, all samples passed the TCLP treatment standard. This grout formulation retained the high mercury content of the projected NGLW. 
Table 13. Mercury Content in NGLW Simulant, Grout, and TCLP Extract

\begin{tabular}{|c|c|c|c|c|c|c|c|}
\hline Test & $\begin{array}{c}\text { Hg in } \\
\text { Initial } \\
\text { Simulant } \\
(\mathrm{mg} / \mathrm{L})\end{array}$ & $\begin{array}{c}\mathrm{Hg}\left(\mathrm{NO}_{3}\right)_{2} \\
\bullet \mathrm{H}_{2} \mathrm{O} \\
\text { Added to } \\
113 \mathrm{~g} \\
\text { Simulant } \\
(\mathrm{mg}) \\
\end{array}$ & $\begin{array}{c}\text { Hg in } \\
\text { Doped } \\
\text { Simulant } \\
(\mathrm{mg} / \mathrm{L})^{*}\end{array}$ & $\begin{array}{c}\text { Hg in } \\
\text { Doped } \\
\text { Simulant } \\
\text { (mg/kg)* }\end{array}$ & $\begin{array}{c}\text { Hg in } \\
\text { Grout } \\
\text { (mg/kg)* }\end{array}$ & $\begin{array}{l}\text { Hg in } \\
\text { Grout } \\
(\mathrm{mg} / \mathrm{L})^{*}\end{array}$ & $\begin{array}{c}\text { Hg in } \\
\text { TCLP } \\
\text { Extract } \\
(\mathrm{mg} / \mathrm{L})\end{array}$ \\
\hline 1 & 500 & 0 & 500 & 420 & 180 & 280 & $9.4 \mathrm{E}-4$ \\
\hline 2 & 500 & 50 & 780 & 650 & 290 & 460 & $* *$ \\
\hline 3 & 500 & 100 & 1050 & 880 & 390 & 620 & $2.2 \mathrm{E}-4$ \\
\hline 4 & 500 & 150 & 1330 & 1110 & 490 & 780 & $2.0 \mathrm{E}-4$ \\
\hline 5 & 500 & 200 & 1600 & 1330 & 590 & 940 & $1.9 \mathrm{E}-4$ \\
\hline 6 & 500 & 250 & 1870 & 1560 & 700 & 1120 & $1.5 \mathrm{E}-4$ \\
\hline 7 & 500 & 380 & 2590 & 2160 & 970 & 1550 & $3.5 \mathrm{E}-4$ \\
\hline 8 & 500 & 470 & 3080 & 2570 & 1150 & 1840 & $* *$ \\
\hline 9 & 500 & 560 & 3570 & 2980 & 1340 & 2140 & $* *$ \\
\hline 10 & 500 & 650 & 4070 & 3390 & 1520 & 2430 & $1.0 \mathrm{E}-3$ \\
\hline 11 & 500 & 750 & 4610 & 3850 & 1730 & 2760 & $1.8 \mathrm{E}-4$ \\
\hline 12 & 500 & 840 & 5110 & 4260 & 1910 & 3050 & $1.4 \mathrm{E}-4$ \\
\hline
\end{tabular}

* Calculated values. All others are measured values. ** Less than detection limit of $1 \mathrm{E}-5 \mathrm{mg} / \mathrm{L}$.

\section{SILICA GEL PROCESS FOR SODIUM BEARING WASTE}

The suitability of using the silica gel process for Idaho National Engineering and Environmental Laboratory (INEEL) sodium bearing waste was investigated during fiscal year 2000. The study was cofunded by the Tanks Focus Area as part of TTP No. ID-77WT-31 and the High Level Waste Program. The task also included the investigation of possible other absorbents. Scoping tests and examination of past work showed that the silica gel absorption/adsorption and drying method was the most promising; thus only silica gel was studied and not other absorbents. The documentation on the Russian silica gel process provided much of the needed information but did not provide some of the processing detail so these facts had to be inferred or gleaned from the literature ${ }^{7,8}$.

The Russian process is designed to sorb solutions into silica gel; then, drive out the water and any acids that may form by heating to a temperature near $120^{\circ} \mathrm{C}$. This treatment results in a dry flowing intermediate product that is suitable for storage. The intermediate product can be calcined at high temperatures for a permanent waste form or the metals can be recovered from the gel by leaching with nitric acid. The intermediate product can be converted into a glass or cement waste forms.

The silica-sol gel technology is an alternative for the treatment of INEEL liquid waste forms. It employs adsorption/absorption, chemical reaction and evaporation for the first step. Per review of the literature $^{7,8}$ and further evaluation of the chemistry, it appeared feasible to denitrate at least a fraction of the INEEL sodium bearing waste by vaporizing nitric acid at a reasonably low temperature. Further denitration also appeared possible without the addition of reductant materials. Processing may be feasible on the other projected INEEL low activity liquid waste streams. 
Information from the literature ${ }^{9,10}$ indicates that metal ions, especially iron and aluminum, will react with silica gel releasing hydrogen ion:

$$
\mathrm{M}^{\mathrm{n}+}+\mathrm{m}(\mathrm{OSi}-)=\mathrm{M}(\mathrm{OSi}-)_{\mathrm{m}}^{\mathrm{n}-\mathrm{m}}+\mathrm{mH}^{+} \quad \text { Eq. } 1 .
$$

The reaction is reversible in acidic solutions. As the temperature and the concentration is increased during evaporation, the equilibrium is forced to the right. Formed volatile acids are then evaporated off. This releases some of the nitrate as nitric acid, and as indicated in our experimental work, the entire nitrate associated with iron and most of that with aluminum is released at temperatures less than $130^{\circ} \mathrm{C}$.

\subsection{TEST WORK SUMMARY}

Tests were conducted using concentrated sodium bearing waste simulant and Grade 12 silica gel to further evaluate the process. The results of these tests are summarized as follows:

1. Product waste loadings to $84 \mathrm{wt} \%$ of the total gel plus simulant mass was dry and flowable when treated at $110^{\circ} \mathrm{C}$.

2. Volume reduction of over $30 \%$ based on the volume of simulant feed was demonstrated.

3. Up to $46 \%$ denitration of the simulant was possible without visible $\mathrm{NO}_{\mathrm{x}}$ production at a temperature up to $132^{\circ} \mathrm{C}$. This indicates that most of the aluminum and iron no longer have nitrate associated and are present in the dried product as different species. The acid concentration of the collected condensate was about 3.5 molar.

4. Leach solutions from the heat treated product produced between 120 and $140^{\circ} \mathrm{C}$ have measured $\mathrm{pH}$ values between 4 and 6 , indicating near complete acid vaporization. When the product was heated to over $400^{\circ} \mathrm{C}$, the $\mathrm{pH}$ of the leach solution was over 10 and most of the sodium was denitrated.

5. Temperatures above $135^{\circ} \mathrm{C}$ produced visible $\mathrm{NO}_{\mathrm{x}}$.

6. Without subsequent treatment, between 50 and $80 \mathrm{wt} \%$ of the calculated dried/absorbed simulant was water leachable. At treatment temperatures above $400^{\circ} \mathrm{C}$, the leachability begins to decrease. At $600^{\circ} \mathrm{C}$ and $81 \mathrm{wt} \%$ loading, the water leachable fraction was reduced to about $5 \mathrm{wt} \%$.

7. The dry gel product can be stored until needed then retrieved for further processing into a glass or cement waste form. Loaded dry gel product is easily made into a glass. It can be fed dry to a melter without concern about hot acid vapors in the offgas. All three test glasses made from the SBW product passed the PCT test. The glasses appeared to be free from crystallization and the $80 \mathrm{wt} \%$ loaded gel produced a glass with an overall simulant to glass volume reduction ratio of near 10 .

8. The TCLP leaching failed on all the non-glass products tested. Chromium, cadmium, and lead leached from the dry gel product. Mercury was not detected in the leach solutions. 


\subsection{EXPERIMENTAL}

\subsubsection{Initial Testing}

Scoping tests were performed to determine the maximum desirable waste loading. The waste simulant used was from the concentrated sodium bearing waste flowsheet dated 12/9/98. The constituents used to makeup the simulant are shown as Table 14. Two types of gel were used: one a course grade 12 and the other a chromographic grade silicic acid of 240 mesh.

Table 14. Concentrated Sodium Bearing Waste Simulant Composition

\begin{tabular}{|c|c|c|}
\hline Species & $\begin{array}{c}\text { SBW-LAW } \\
\text { Average } \\
\text { (gmol/L) }\end{array}$ & $\begin{array}{l}\text { Stock Chemicals Used for } \\
\text { Mixing the Simulants }\end{array}$ \\
\hline Acidity & 1.94 & $\mathrm{HNO}_{3}, \mathrm{HBF}_{4}$, etc \\
\hline $\mathrm{Al}$ & 0.784 & $\mathrm{Al}\left(\mathrm{NO}_{3}\right)_{3}$ sol'n \\
\hline $\mathrm{B}$ & 0.0191 & $\mathrm{HBF}_{4} 50 \%$ solution \\
\hline $\mathrm{Ba}$ & $7.23 \mathrm{E}-5$ & $\mathrm{Ba}\left(\mathrm{NO}_{3}\right)_{2}$ \\
\hline $\mathrm{Ca}$ & 0.0576 & $\mathrm{CaO}$ \\
\hline $\mathrm{Cd}$ & 0.0001 & $\mathrm{Cd}\left(\mathrm{NO}_{3}\right)_{2} \cdot 4 \mathrm{H}_{2} \mathrm{O}$ \\
\hline $\mathrm{Cl}$ & 0.0405 & $\mathrm{HCl}$ \\
\hline $\mathrm{Cr}$ & $0.0001^{1}$ & $\mathrm{Cr}\left(\mathrm{NO}_{3}\right)_{3} \cdot 9 \mathrm{H}_{2} \mathrm{O}$ \\
\hline Cs & $2.76 \mathrm{E}-5$ & $\mathrm{CsNO}_{3} \&{ }^{137} \mathrm{CsCl}$ \\
\hline $\mathrm{F}$ & 0.0712 & $\mathrm{HF}, \mathrm{ZrF}_{4}, \mathrm{HBF}_{4}$ \\
\hline $\mathrm{Fe}$ & 0.0271 & $\mathrm{Fe}\left(\mathrm{NO}_{3}\right)_{3} \cdot 9 \mathrm{H}_{2} \mathrm{O}$ \\
\hline $\mathrm{Hg}$ & $0.0001^{\top}$ & $\mathrm{Hg}\left(\mathrm{NO}_{3}\right)_{2} \cdot \mathrm{H}_{2} \mathrm{O}$ \\
\hline $\mathrm{K}$ & 0.245 & $\mathrm{KNO}_{3}$ \\
\hline $\mathrm{Mg}$ & -- & $\mathrm{MgO}$ \\
\hline $\mathrm{Mn}$ & 0.0159 & $\mathrm{Mn}\left(\mathrm{NO}_{3}\right)_{2}$ sol'n \\
\hline Mo & 0.000843 & $\mathrm{MoO} 3$ \\
\hline $\mathrm{Na}$ & 2.36 & $\mathrm{NaNO}_{3}$ \\
\hline $\mathrm{Ni}$ & 0.00227 & $\mathrm{Ni}\left(\mathrm{NO}_{3}\right)_{2} \cdot 6 \mathrm{H}_{2} \mathrm{O}$ \\
\hline $\mathrm{NO}_{3}$ & 6.95 & $\mathrm{HNO}_{3}, \mathrm{Ca}\left(\mathrm{NO}_{3}\right)_{2}, \mathrm{NaNO}_{3}$, etc \\
\hline $\mathrm{Pb}$ & $0.0001^{1}$ & $\mathrm{~Pb}\left(\mathrm{NO}_{3}\right)_{2}$ \\
\hline $\mathrm{PO}_{4}^{-3}$ & 0.0204 & $\mathrm{H}_{3} \mathrm{PO}_{4}$ \\
\hline $\mathrm{Sr}$ & $2.04 \mathrm{E}-5$ & $\mathrm{Sr}\left(\mathrm{NO}_{3}\right)_{2}$ \\
\hline $\mathrm{SO}_{4}^{-2}$ & 0.0637 & $\mathrm{H}_{2} \mathrm{SO}_{4}$ \\
\hline $\mathrm{TcO}_{4}^{-}$ & $1.17 \mathrm{E}-5$ & $\mathrm{NH}_{4} \mathrm{TcO}_{4}$ \\
\hline $\mathrm{ZrOF}^{-}$ & 0.00731 & $\mathrm{ZrF}_{4}$ \\
\hline
\end{tabular}

${ }^{1}$ Amount added to be below possible RCRA concern for most of the work.

An initial test was conducted using the silicic acid. The mixture was allowed to dry over the weekend at ambient temperature and became free flowing with yellow coloration and some crustiness. This product was then placed in an oven overnight at $115^{\circ} \mathrm{C}$ and the indicated weight loss of dried simulant was over $82 \%$. The sample was leached with demineralized water and the centrifuged solution 
evaporated. The dried solids from the solution indicated a leachability of just less than $80 \mathrm{wt} \%$ for the sample. To determine the species that leached out, the dried leachates were submitted for XRD and a SEM semi-quantitative analysis. Sodium nitrate appeared as the major crystalline form with some potassium nitrate. In the SEM, sodium appeared with the large crystals with the potassium deposited on the edges. A small amount of aluminum was also present.

For the subsequent comparison test, both types of gel were used and performance was about the same. The gel amounts were weighed out and the simulant was added for waste loadings of $60,70,80$ and 85 weight percent. When mixed, all but the $60 \%$ loaded samples had free liquid above the gel volume. The $60 \%$ loaded samples had the consistency of wet sand. The beakers containing the mixtures were placed in an oven set at $100^{\circ} \mathrm{C}$ for four hours and removed for weighing. The liquid was essentially gone for the 60 and $70 \%$ loaded gels with minor crusting forming on the $70 \%$ sample. The other two loadings still had standing liquid. All eight were stirred and returned to the oven set at $120^{\circ} \mathrm{C}$. This process was repeated once more to the temperature of $140^{\circ} \mathrm{C}$. The results are shown in Table 15 .

Table 15. Percent of Indicated Simulant Mass Remaining After Evaporation at Temperature

\begin{tabular}{|c|c|c|c|c|}
\hline Sample & $\begin{array}{c}\text { Actual } \\
\text { Loading } \\
\text { \% }\end{array}$ & $\mathbf{1 0 0}^{\circ} \mathbf{C}$ & $\mathbf{1 2 0}^{\circ} \mathbf{C}$ & $\mathbf{1 4 0}^{\circ} \mathbf{C}$ \\
\hline $60-1$ & 57.1 & 24.7 & 17.1 & 15.7 \\
\hline $70-1$ & 69.9 & 56.5 & 20.2 & 19.5 \\
\hline $80-1$ & 82.1 & 60.0 & 23.3 & 22.1 \\
\hline $90-1$ & 85.2 & 61.1 & 33.6 & 22.1 \\
\hline & & & & \\
\hline $60-2$ & 59.8 & 35.1 & 22.1 & 20.8 \\
\hline $70-2$ & 72.5 & 48.7 & 20.1 & 19.3 \\
\hline $80-2$ & 80.1 & 57.9 & 23.5 & 22.7 \\
\hline $90-2$ & 85.0 & 58.2 & 28.3 & 23.6 \\
\hline
\end{tabular}

From Table 15, it is apparent that for all the waste loadings tested, more than $75 \%$ of the mass can be removed at $140^{\circ} \mathrm{C}$. Most of this is water and nitric acid. The heavy crusting formed on the samples loaded above $80 \mathrm{wt} \%$ rendered them non-flowing mixtures. Subsequent results have shown that the product is flowable with waste loadings up to $84 \mathrm{wt} \%$. The grade 12 silica gel was chosen for subsequent testing because of better handling characteristics and because the silicic acid did not present a more noticeable advantage. This was the same conclusion reached in prior work ${ }^{2}$.

The weight loss of silica gel on heating alone was determined so that the accuracy of the simulant loss values could be determined. Losses varied from $0.99 \%$ at $100^{\circ} \mathrm{C}$ to $1.9 \%$ at $140^{\circ} \mathrm{C}$. A Grade 12 gel sample taken to $850^{\circ} \mathrm{C}$ for seven hours showed a weight loss of $2.34 \%$. An XRD on the unheated gel showed only amorphous material. This indicates that the raw gel material contains very little other than $\mathrm{SiO}_{2}$.

\subsubsection{Loading Tests}

From the work above, it appeared that the loading could be increased above $70 \mathrm{wt} \%$ and still avoid the crusting if the simulant were added incrementally to the gel. Enough simulant was added to the silica gel to approximate a waste loading of 50\%. Smaller amounts were added after partial evaporation had occurred until the loading was about $75 \%$ (actual 
$72.3 \mathrm{wt} \%$ ). After the final addition, the sample was placed in the oven at $120^{\circ} \mathrm{C}$ for the weekend. The results of this experiment, the iterative addition experiment, were not entirely satisfactory because there was minor crusting. Most of the crusting was avoided in later test work by more frequent stirring. Continuous stirring of the mixture at temperatures near $110^{\circ} \mathrm{C}$ eliminated the crusting while allowing for waste loadings above $80 \mathrm{wt} \%$.

Looking at the SEM pictures of the particles, Figures 12 and 13, two things are apparent: there are smaller particles throughout the solids of the loaded gel, Figure 13, and the average size of the larger particles is smaller than in the unloaded gel, Figure 12.

Figure 12. Grade 12 Silica Gel at $50 x$

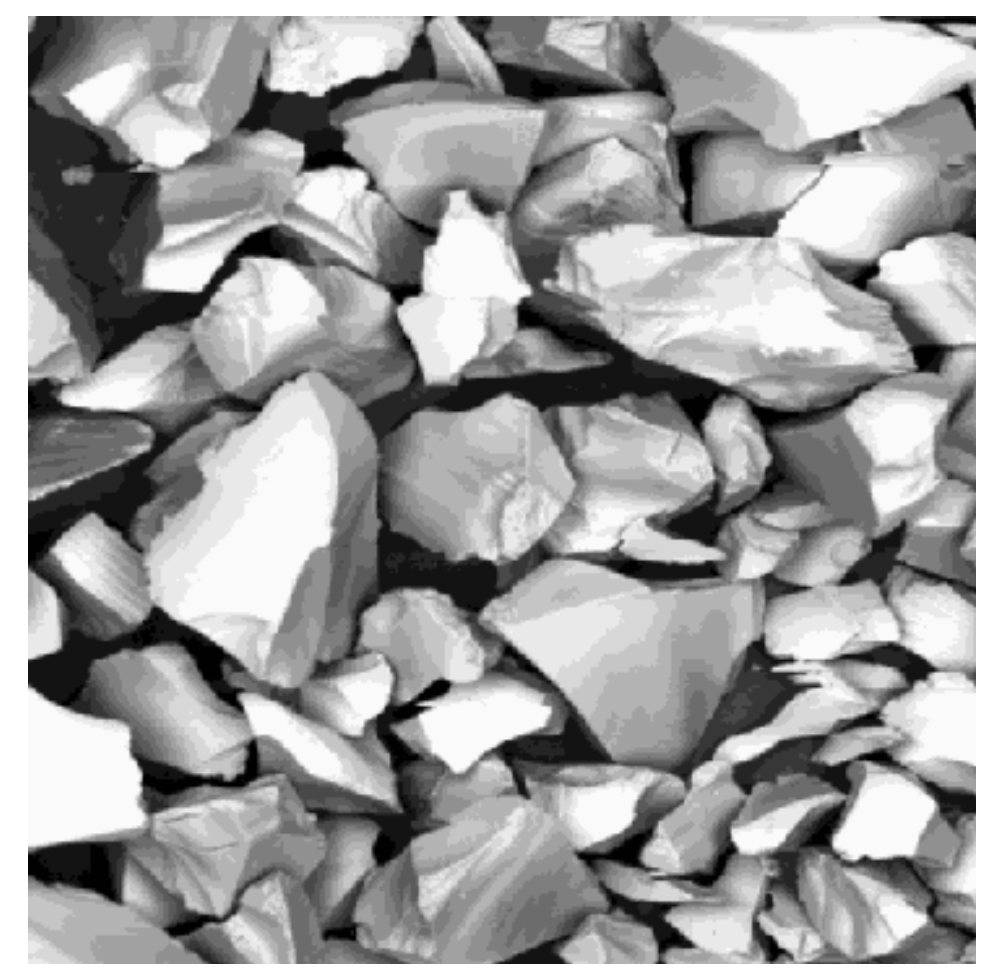

Apparently the silica gel spalled off small chunks during the process of alternate evaporation and cycling of temperature. The SEM semi-quantitative analysis results, shown in Table 16, indicate the smaller size fraction to be enriched in Na and relatively depleted in Si and Al. An XRD analysis showed mainly amorphous material with sodium nitrate as the major crystalline component with an unidentified major. The great difference in $\mathrm{Na}$ in the overall analysis tends to indicate surface precipitation in the iterative experiment. SEM analyses determine only surface values and will not indicate the absorbed chemicals. Also shown in Table 3 is the semi-quantitative analysis of Run 3, which had a waste loading of $60 \mathrm{wt} \%$. 
Figure 13. Loaded Grade 12 Silica Gel $-72.3 \mathrm{wt} \%$ at $50 x$

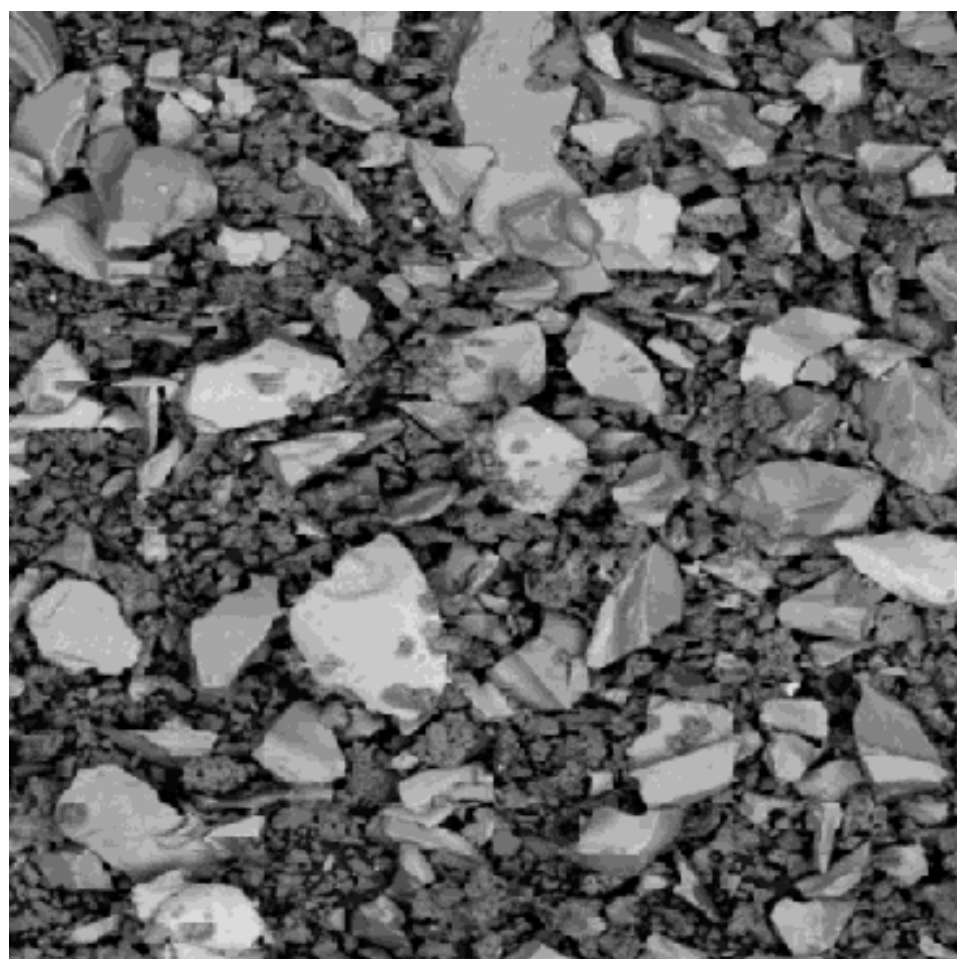

Table 16. Scanning Electron Microscope (SEM) Semi-Quantitative Analysis

\begin{tabular}{|l|c|c|c|c|c|}
\hline Element At \% & Na & Al & Si & S & K \\
\hline Figure 13 & & & & & \\
\hline Both Phases & 10.92 & 3.88 & 21.74 & 0.49 & 0.84 \\
\hline Small Particles & 31.86 & 3.56 & 7.71 & 0.82 & 0.66 \\
\hline Large Particles & 2.79 & 4.2 & 27.02 & 0.4 & 0.84 \\
\hline Figure 14 & & & & & \\
\hline R-3 All & 4.24 & 1.96 & 28.59 & 0.4 & 0.42 \\
\hline
\end{tabular}

The iterative test sample was screened with the separation at 150 microns. Mass fraction retained by the larger particle fraction was $68.5 \%$. Both fractions were leached in demineralized water, centrifuged, rinsed, centrifuged again, and then placed over a weekend in the oven at $132^{\circ} \mathrm{C}$. The leachable fraction of smaller size particles was $26.3 \mathrm{wt} \%$ and contained $15.5 \%$ of total gel product mass. The leachable fraction of the larger particles contained $10.8 \%$ of the total gel product mass. It may be that the gel became saturated or the pores became choked off during the process such that the simulant added later had to evaporate on the surfaces. The smaller particles also provided more area and greater overall surface tension to get the liquid to adhere. A summary of this and other results are presented in Table 17 with the results of the mass balance experiments. 


\subsubsection{Mass Balance Runs}

A series of five experiments were conducted to obtain information about the vapor emitted and provide a mass balance. A flask located inside a convection oven was connected through the oven wall to a condenser, followed by a condensate collection vessel and Drierite column. The first two runs did not have a purge gas and they did not reach the evaporative loss of mass indicated by the prior experiments. A loss as percentage of starting simulant was 61 to $63 \mathrm{wt} \%$ as opposed to $75 \mathrm{wt} \%$ on the iterative addition test above and about $80 \mathrm{wt} \%$ on some of the earlier scoping tests. These lower values resulted despite leaving the system running at temperature overnight. It was believed that the system contained a large closed volume and because the earlier tests were conducted in open containers with natural convection, that a purge was necessary. Normal mass diffusion may have been too slow. Due to the lack of evaporation in the earlier tests, Run 3 was operated with a purge line connected to the heated flask. An air purge rate of about $900 \mathrm{ml} / \mathrm{hr}$ was used. This resulted in an evaporative loss of $78.7 \mathrm{wt} \%$ as a percentage of starting simulant. A SEM picture of the Run 3 product is shown as Figure 14. It can be noted that there are very few of the smaller particles observed in the picture from the iterative experiment. Screening of the Run 3 product showed an $8.9 \mathrm{wt} \%$ fraction below 150 microns. A factor of three less than the iterative experiment product. This value is about half the highest value for the original gel, 16.8 wt $\%$.

Figure 14. Loaded Grade 12 Silica Gel - Run 3 Product $60.1 \mathrm{wt} \%$ at $50 x$

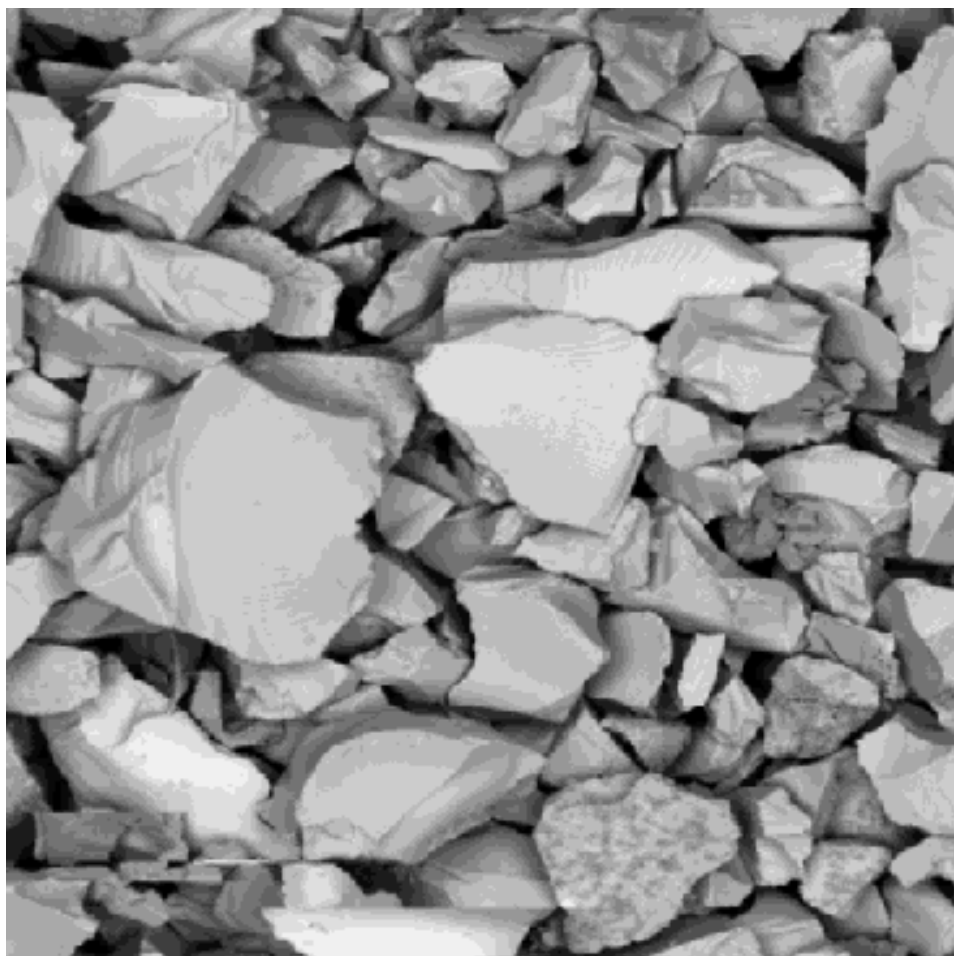

The Russian Gupka was tested with sodium bearing waste. The material is mostly $\mathrm{SiO}_{2}$ and was supplied as a cylinder of modified sintered coal fired fly ash. A Gupka run was set up in a like manner to Run 3 with periodic additions of raw concentrated simulant to the cylinder after some interim evaporation. As more and more simulant was added to the surface of the cylinder, the void space between the particles began to seal off. Eventually no more simulant would absorb. It was apparent that there was more void space within the cylinder and information that was available indicated such. Some surface reaction of the simulant with Gupka material had sealed the pathways to the interior. Even so, the waste loading was nearly $70 \mathrm{wt} \%$. It has been surmised but not verified that the small amount of fluoride in the 
SBW attacked the silica during the evaporative concentration. There were also indications the temperature could have an effect. The results of the measured parameters of the Gupka experiment are summarized with the other runs in Table 17.

Table 17. Comparison of Silica Gel Experiments and Gupka Material with Sodium Bearing Waste Simulant

\begin{tabular}{|c|c|c|c|c|c|c|c|c|}
\hline Parameter $\backslash$ Experiment & $\begin{array}{c}\text { Scoping Test } \\
70-2\end{array}$ & $\begin{array}{c}\text { Iterative } \\
\text { Addition Test }\end{array}$ & Run 1 & Run 2 & Run 3 & Gupka & $\begin{array}{c}\text { Run } 4 \\
\text { (iterative) }\end{array}$ & $\begin{array}{l}\text { 84H Max } \\
\text { Load }\end{array}$ \\
\hline $\begin{array}{c}\text { Waste Loading-Simulant \% of } \\
\text { Total Mass }\end{array}$ & 72.5 & 73.2 & 66.5 & 50.1 & 60.1 & 69.3 & 80.1 & 84.24 \\
\hline $\begin{array}{c}\text { Calculated wt } \% \text { of Simulant } \\
\text { left } @ 120^{\circ} \mathrm{C}\end{array}$ & 23.5 & 24.6 & 58.2 & NA & 28.8 & NA & NA & 42.9 \\
\hline $\begin{array}{c}\text { Calculated wt } \% \text { of Simulant } \\
\text { left } @ 132^{\circ} \mathrm{C}\end{array}$ & NA 19.3@140 & NA & 38.2 & 37.31 & 21.33 & 24.27 & 26.3 & NA \\
\hline $\begin{array}{c}\text { Accountability Mass Balance } \\
\%\end{array}$ & NA & NA & 99.21 & 95.2 & 98.6 & 98.3 & 99 & NA \\
\hline Sp. Gr. of Final Condensate & NA & NA & 1.0798 & 1.067 & 1.113 & 1.111 & 1.119 & NA \\
\hline $\begin{array}{c}\text { Concentration of Acid in } \\
\text { condensate } \underline{M}\end{array}$ & NA & NA & 2.42 & 2.03 & 3.75 & 3.6 & 3.57 & NA \\
\hline $\begin{array}{c}\text { Calculated Denitration Based } \\
\text { on } \mathrm{HNO} 3 \text { in Condensate } \%\end{array}$ & NA & NA & 25.61 & 18.92 & 45.92 & 50.2 & 43.4 & NA \\
\hline Bulk Density of Product $\mathrm{g} / \mathrm{cm} 3$ & 0.882 & 0.914 & 0.829 & 0.702 & 0.844 & 0.606 & 1.002 & 1.008 \\
\hline $\begin{array}{l}\text { Volume Change based on } \\
\text { Starting Simulant }+/-\%\end{array}$ & -10.10 & -10.10 & 40.60 & 157.00 & 37.00 & 47.9 & -32.6 & -44.1 \\
\hline $\begin{array}{c}\text { Swelling Based on Starting } \\
\text { Gel Volume \% }\end{array}$ & 129.00 & 132.00 & 156.00 & 145.00 & 116.00 & NA & 148 & 168 \\
\hline $\begin{array}{l}\text { Water Leachability- As \% of } \\
\text { calculated dried simulant }\end{array}$ & NA & 63.84 & 57.49 & NA & 51.32 & NA & 62.34 & NA \\
\hline $\begin{array}{l}\text { Calc. Fraction of Dry Solids } \\
\text { Loaded as Oxides in Product }\end{array}$ & 0.21 & 0.21 & 0.17 & 0.09 & 0.13 & 0.18 & 0.29 & 0.35 \\
\hline
\end{tabular}

An iterative run, Run 4, was used to demonstrate production of a good product with a volume reduction of $32.8 \%$ of the original simulant. The increments of simulant were added and mixed while the gel and the vessel were still hot. The losses of material were less than expected with a $99 \%$ mass accountability. The final bulk density was over one. Run 4 product was used for further testing, including one of the glasses.

Heavy metals were added to the simulant and product was made for leach studies. A maximum loading was determined by using the same iterative addition as above. A waste loading of over $85 \mathrm{wt} \%$ was produced but the product was very crusty. Two other products were made from the hazardous simulant, one at $84.2 \mathrm{wt} \%$ and one at $80.9 \mathrm{wt} \%$. These were designated $84 \mathrm{H}$ and $81 \mathrm{H}$ respectfully. The properties of product $84 \mathrm{H}$ are shown in Table 17. It was discovered that operating the oven at a lower temperature, 105 to $110^{\circ} \mathrm{C}$, allowed the gel to be iteratively loaded much more easily and with less crusting than prior tests. Two other non-hazardous products were made in bulk in open beakers, and designated 70-105 and 75-105. The product from Run 4 was also used in the leach studies and was designated 80-132. 


\subsubsection{Leach Studies}

Products made at lower temperature have been known to leach readily. Past work ${ }^{6,7}$ reported that leachability decreased with temperature. Five products were heat treated overnight at progressively higher temperatures, then leached. The leaching was for a minimum of 20 hours at which time the solids and leachate was separated by centrifugation and the solids washed. The wash solution was separated in like manner and added to the leachate. The solids were then dried overnight at $130^{\circ} \mathrm{C}$ and the weights recorded. Leachates were analyzed for nitrate and $\mathrm{pH}$. Data resulting from these studies is presented in Figures 15 through 17.

Figure 15. Leachability of Heat Treated Product

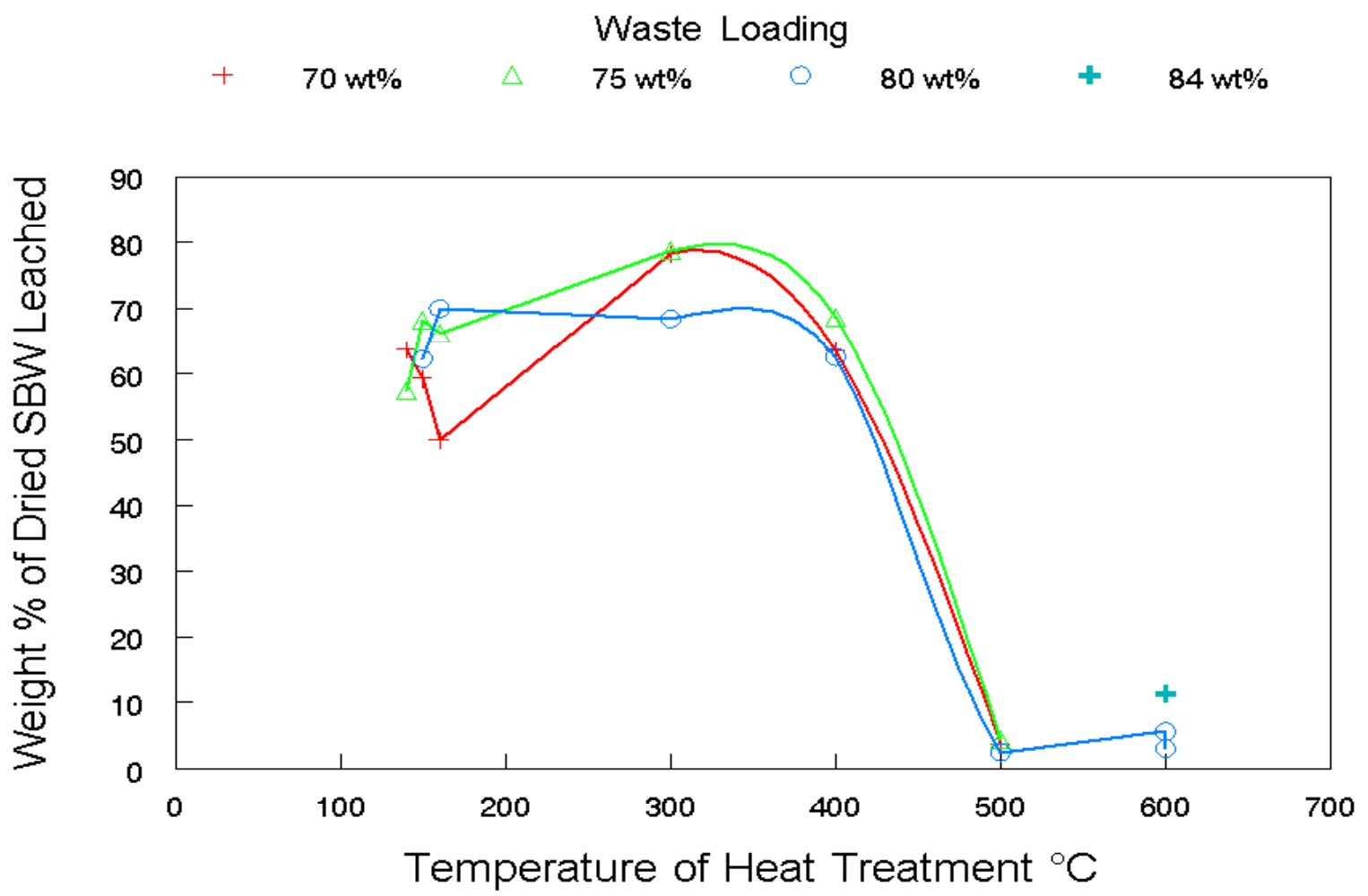

The amount of dried simulant leached from the product at the different loadings and temperature treatments using ambient temperature water is shown in Figure 15. The leachability increases from $160^{\circ}$ to $300^{\circ} \mathrm{C}$ then decreases to $400^{\circ} \mathrm{C}$ and drops off at $500^{\circ} \mathrm{C}$. The pattern is fairly consistent. At temperatures near $300^{\circ} \mathrm{C}$ the alkali metal nitrates lose all water and between 307 and $334^{\circ} \mathrm{C}$ the anhydrous forms are liquid. What nitrates may have been "locked in the gel matrix" are then more mobile. The leachability is about the same after treatment at $400^{\circ} \mathrm{C}$ as it was at about $150^{\circ} \mathrm{C}$. Apparently at $500^{\circ} \mathrm{C}$ the pores within the gel are closing off.

The $\mathrm{pH}$ of the leachates are above 10 after $400^{\circ} \mathrm{C}$ as shown in Figure 16 . There may be some alkaline attack on the gel because of obvious denitration. The attack may help in sealing off the gel pores. 
Figure 16. Leachate $\mathrm{pH}$ vs Temperature of Treatment

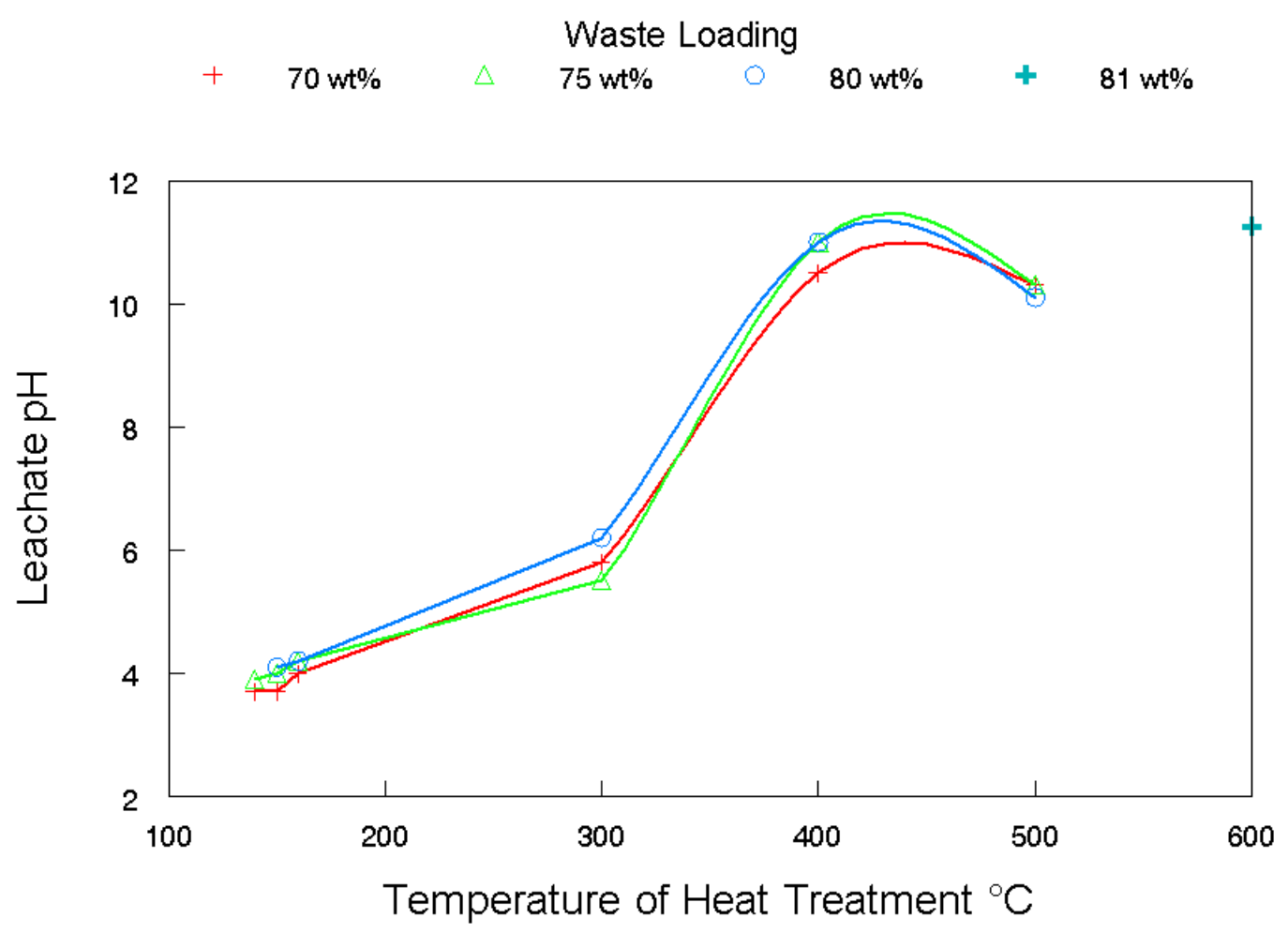

A plot of leachate $\mathrm{pH}$ with temperature is shown in Figure 16. There is a steady increase of value with temperature treatment. With a loss of acidity after $300^{\circ} \mathrm{C}$, the leachates become alkaline. It is not presently known why there is a dip in $\mathrm{pH}$ at the $500^{\circ} \mathrm{C}$ leachate. It may be that the freed $\mathrm{Na}_{2} \mathrm{O}$ is reacting with the silica. The results are consistent across waste loadings. The amount of nitrate in the leachates as a fraction of dried simulant was about the same at all temperature treatments up to $500^{\circ} \mathrm{C}$. There was variability but no obvious trends. This indicates that there was not a complete denitration at $500^{\circ} \mathrm{C}$.

To keep track of dried simulant to product fraction, weights were taken before and after the product heat treatment. A summary of the dried simulant weight decrease versus temperature is presented as Figure 17. The fraction of the original simulant mass is plotted with temperature. There is no plateau of loss with temperature and product 70-105 has decreased to about 0.12. Calculated values for the simulant components as oxides are about 0.10 weight fraction remaining, thus, product $70-105$ was nearly denitrated at $500^{\circ} \mathrm{C}$.

The $81 \mathrm{H}$ product was prepared for TCLP by heating to $170^{\circ} \mathrm{C}$ to drive off more of the acid while still leaving some bound water. Sodium sulfide was added in double the stoichiometric amount to reduce and react with the heavy metals and mixed in just enough water to make the loaded gel moist. The gel immediately turned black. After about 3 minutes, a green-yellow precipitate formed in the available free liquid. Two sulfide treated gels were prepared and dried at $135^{\circ} \mathrm{C}$ overnight. Each of the samples was tumbled with TCLP leach solution. Total exposure to the solution was 19 hours with the tumbling done for four hours at a faster rate than the TCLP procedure. Another treatment was also leached. An aliquot 
Figure 17. Retained Weight Fraction of Simulant

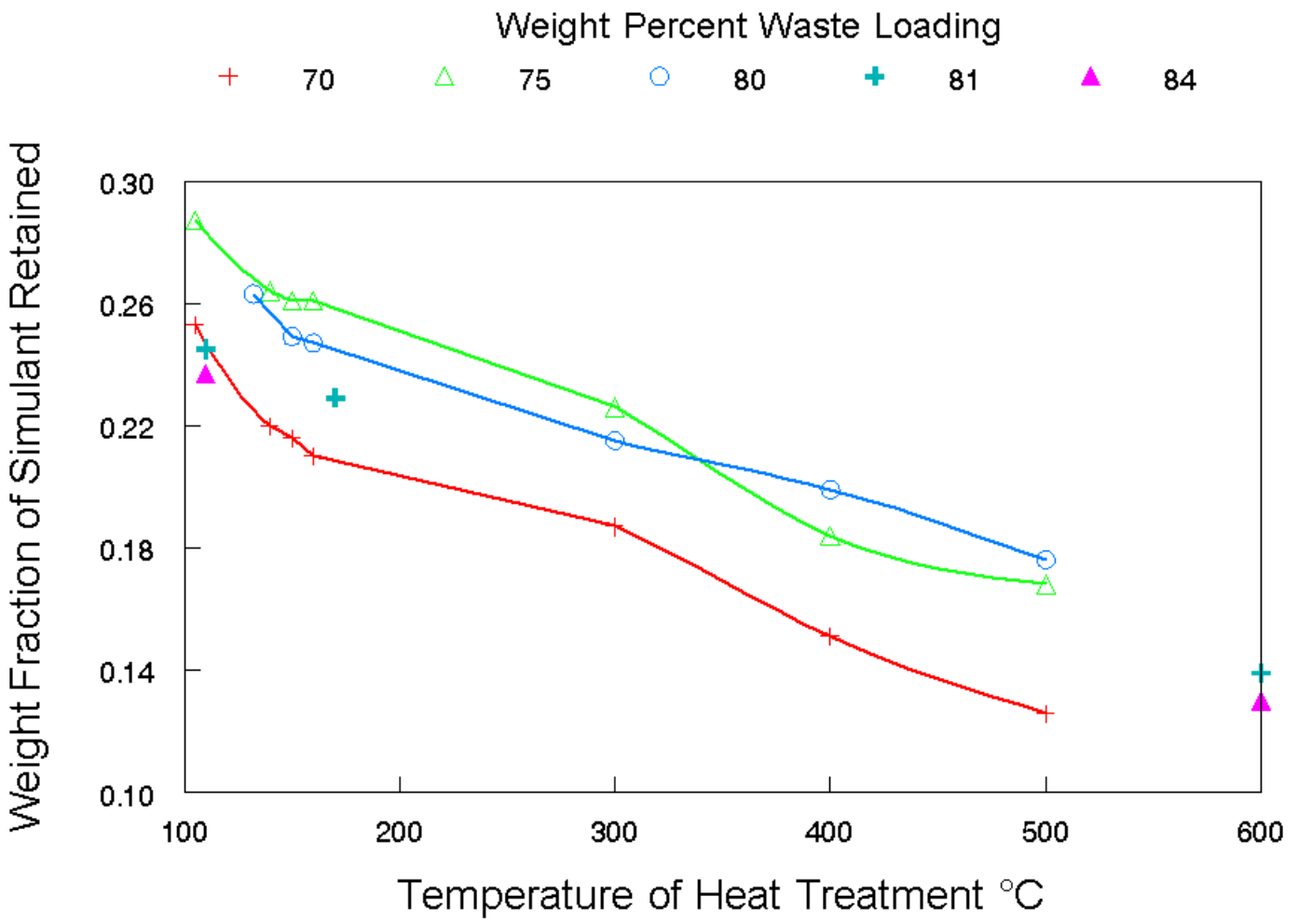

of the $81 \mathrm{H}$ product (heat treated at $600^{\circ} \mathrm{C}$ ) was water leached at ambient temperature for 24 hours, rinsed, and dried in the same manner as the other water leached samples. This water leached product was then submitted to the same modified TCLP procedure as the sulfide treated samples.

It is apparent that the treated material does not pass TCLP as shown in Table 18. The chromium value for the water leached $81 \mathrm{H}$ at $600^{\circ} \mathrm{C}$ barely makes it at $0.46 \mathrm{mg} / \mathrm{L}$. The limit is $0.6 \mathrm{mg} / \mathrm{L}$.

The cadmium fails all the acedic acid treatments but is apparently precipitated during the water leach at a higher $\mathrm{pH}$. If the chromium is heated in oxidizing conditions it will be present at least partially in the very soluble hexavalent state. It must be treated after most of the denitration has occurred where the leachate $\mathrm{pH}$ would be higher and the oxidizing potential lower.

Table 18. Equivalent TCLP Leach Solution Analysis

\begin{tabular}{|c|c|c|c|c|}
\hline & $\begin{array}{c}\text { Sulfide Treated } \\
\text { 81H170 Acedic Acid } \\
\text { Leach 1 (mg/L) }\end{array}$ & $\begin{array}{c}\text { Sulfide Treated } \\
\mathbf{8 1 H 1 7 0} \text { Acedic Acid } \\
\text { Leach 2 (mg/L) }\end{array}$ & $\begin{array}{c}\text { Water Washed } \\
\text { 81H170 Acedic Acid } \\
\text { Leach (mg/L) }\end{array}$ & $\begin{array}{c}\text { 81H170 Water } \\
\text { Leach (mg/L) }\end{array}$ \\
\hline $\mathrm{Cr}$ & 9.91 & 8.46 & 0.46 & 12.76 \\
\hline $\mathrm{Pb}$ & 4.28 & 3.61 & 0.77 & 0.23 \\
\hline $\mathrm{Cd}$ & 30.79 & 29.12 & 6.49 & 0.11 \\
\hline $\mathrm{Hg}$ & $>0.1$ & $>0.1$ & $>0.1$ & $>0.1$ \\
\hline
\end{tabular}




\subsubsection{Microscopic Examination}

The loaded gel particles are translucent when treated at low temperature. There is no visual indication of surface dried simulant. The yellow coloration appears to be uniform throughout each particle with some richer in color than others. When heated to over $130^{\circ} \mathrm{C}$ in open air, the loaded particles turn brown but are still translucent. The greater the waste loading, the darker the color. There is little perceptible change in the particle appearance until the $300^{\circ} \mathrm{C}$ treatment. At this point some sintering together of the smaller particles occurs and there are a small number of white opaque particles. The translucent brown particles have darkened. At higher temperatures, $400^{\circ} \mathrm{C}$ and $500^{\circ} \mathrm{C}$, there is little change in the darkening but there are more opaque particles and less sintering together. The changes from translucent to opaque indicate a chemical reaction within the dried simulant, between the simulant and the gel, or physical changes within the gel. All three could be possible.

Some of the heat treated gel product was submitted for SEM pictures and semi-quantitative analysis. Samples of the same gel products were also submitted for x-ray diffraction analyses. Scanning electron microscope pictures of $81 \mathrm{H}$ gel after being at temperatures of $110^{\circ} \mathrm{C}, 170^{\circ} \mathrm{C}$, and $600^{\circ} \mathrm{C}$ (Figures 18,19 , and 20 respectfully). It can be seen by examining the SEM pictures that the gel particles are mostly smooth with a possible thin coating of dried simulant. Small surface crystals of less than a micron can be seen at the high magnifications. A smaller number of larger crystals are scattered on the surface. At $600^{\circ} \mathrm{C}$ there is indication of surface changes, the nature of which cannot be fully ascertained until the XRD data is supplied. At the lower temperatures the dried simulant is mostly within the gel particles. The semi-quantitative data indicate little change of surface composition with temperature except at $600^{\circ} \mathrm{C}$ where the surface concentration of the sodium has greatly increased relative to the aluminum and silicon. 
Figure 18. $81 \mathrm{H}$ Product Particle from $110^{\circ} \mathrm{C}$ at Magnifications of $150 x$ and $5000 x$
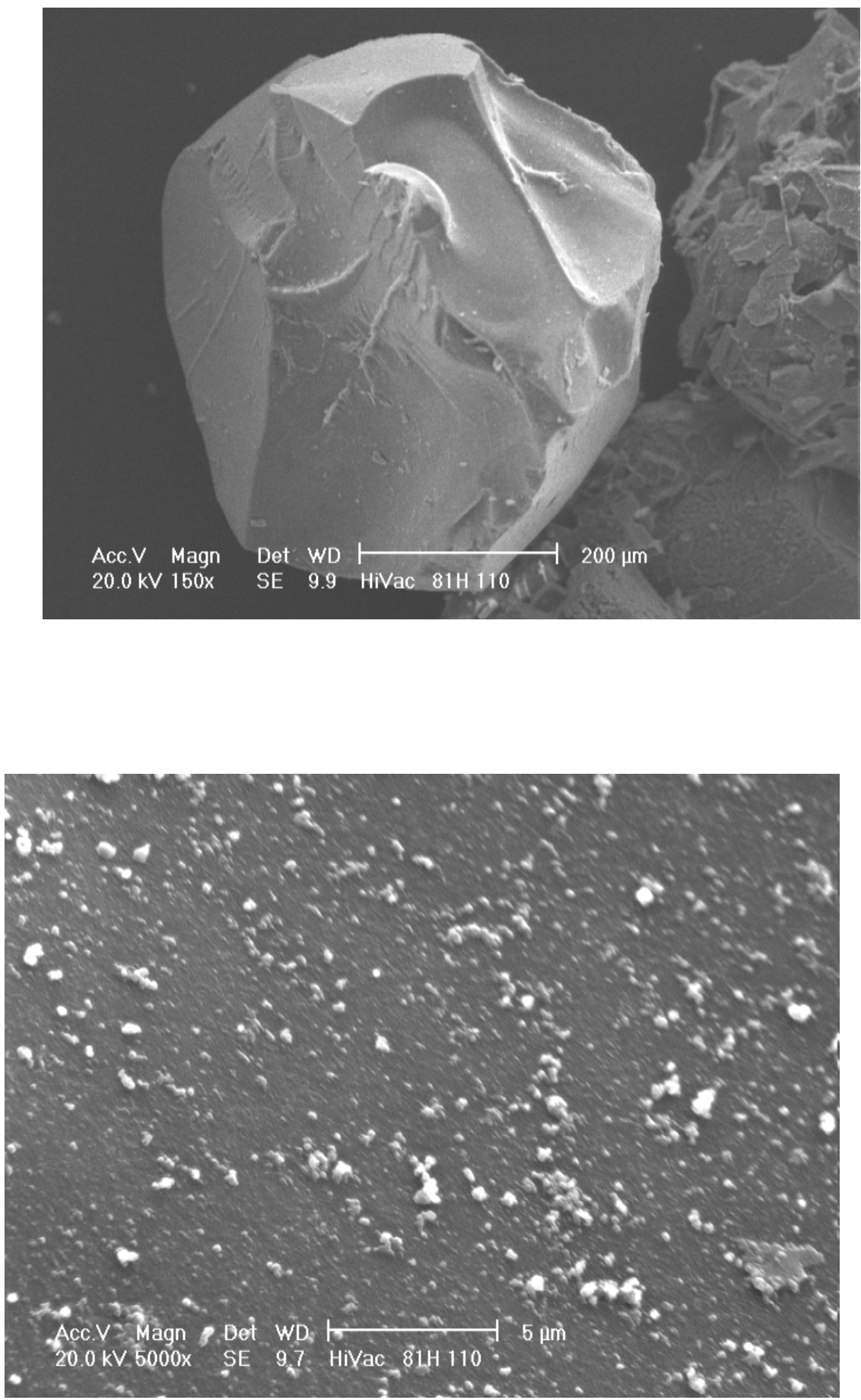
Figure 19. $81 \mathrm{H}$ Product Particle From $170^{\circ} \mathrm{C}$ at Magnifications of $250 x$ and $5000 x$
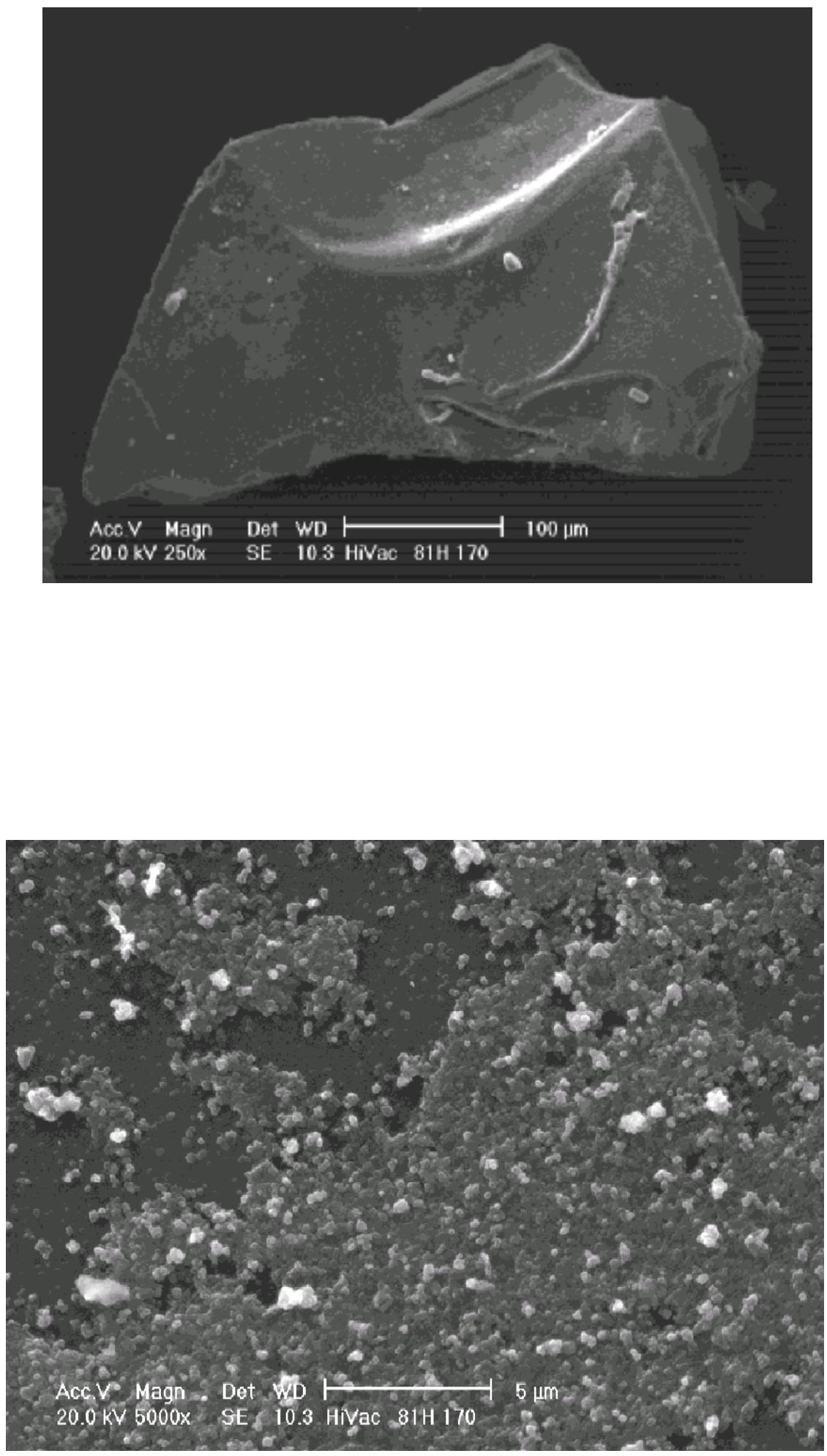
Figure 20. $81 \mathrm{H}$ Product Particle at a Temperature of $600^{\circ} \mathrm{C}$ at Magnifications of $150 x$ and $5000 x$
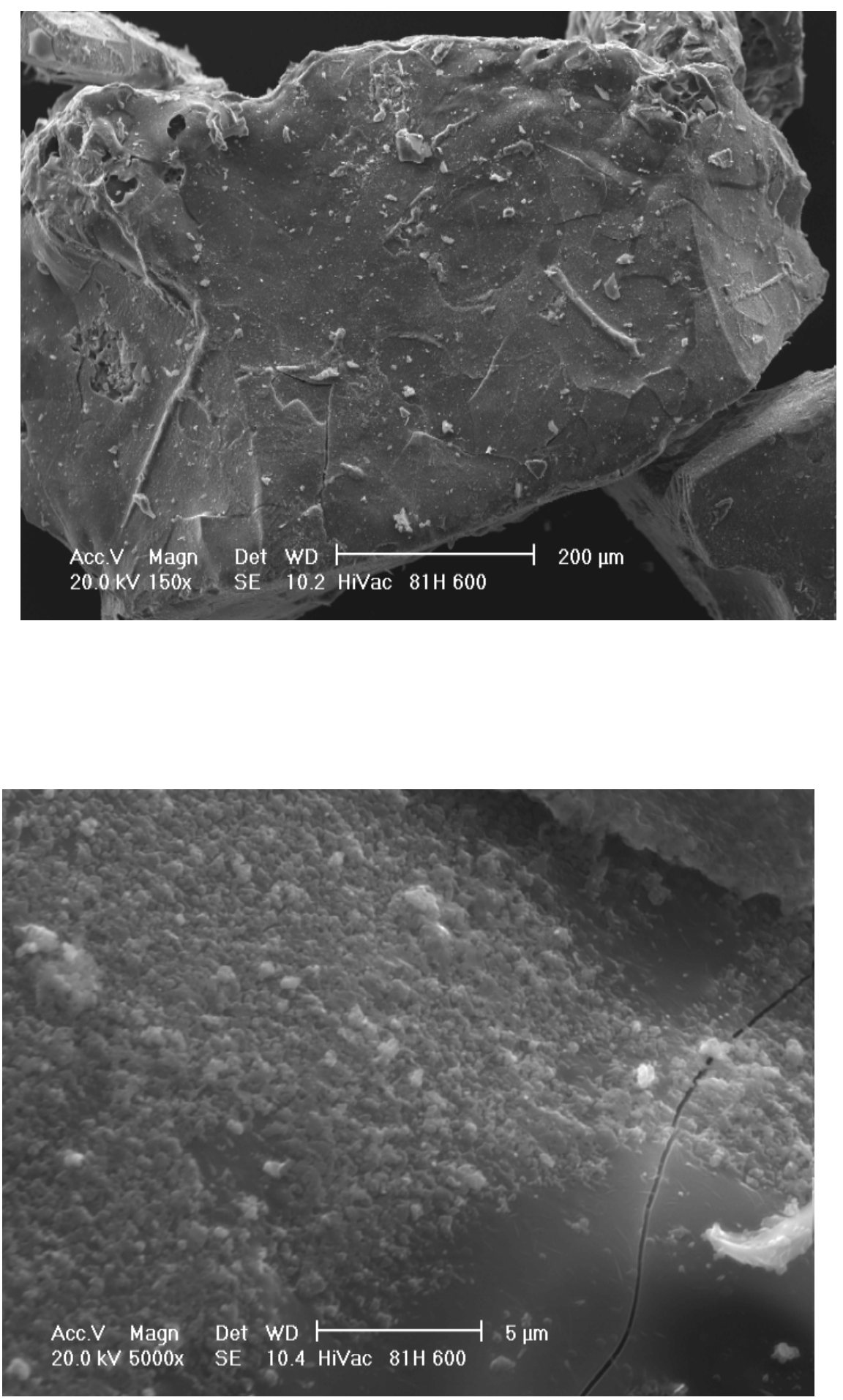


\subsection{Glass Formulation}

The loaded gel contains most components needed to make a glass. It is over rich in silica for the easily formed glasses. Several glass compositions were examined and one was selected that most closely matched the ratios in the loaded gel without too many or too much additives. A formulation nearly duplicating what is called T-glass ${ }^{11}$ was tried. Also tried was a modification of the Clemson glass formulation used on the concentrated SBW. For the formulations, two different waste loaded products were used, one was $70 \mathrm{wt} \%$ from a batch done earlier and the other was at $80 \mathrm{wt} \%$ from Run 4 . The overall formulation and test results are shown as Table 19. The glasses were made by mixing the gel product with the other glass components in a crucible and then melting crucible contents in a furnace at $1200{ }^{\circ} \mathrm{C}$. They were allowed to stay at that temperature for a minimum of 6 hours.

Table 19. Concentrated SBW-Silica Gel Glass Formulation

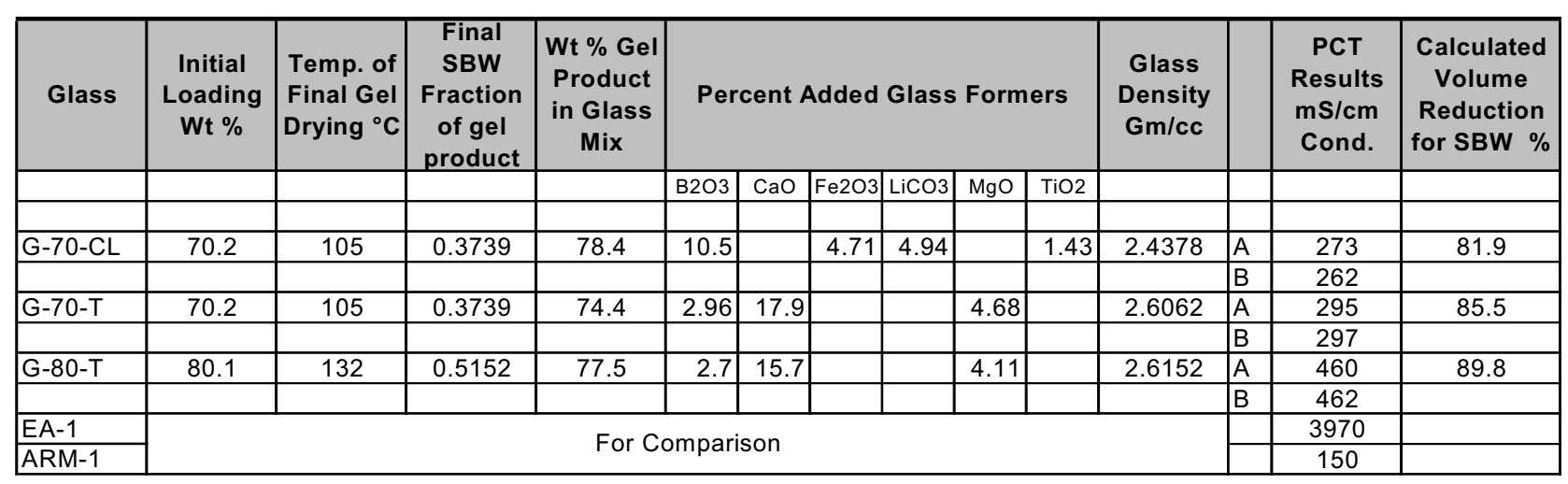

All three glasses performed well in the PCT test and have good volume reduction relative to starting concentrated simulant. There was not enough glass product available to do any viscosity testing.

\subsection{Flowsheet}

A flowsheet was developed from the test data for drying the concentrated sodium bearing waste within and on silica gel (Figure 21). The waste loading is $81 \mathrm{wt} \%$ liquid simulant which becomes $51 \mathrm{wt} \%$ of the dried product. The flow rate used is 10 liter/min of concentrated SBW at a specific gravity of 1.32 . The kinetics of the absorption of the SBW have not been studied in enough detail to size the mixer/drier. Enough residence time is required to assure that the gel becomes saturated. Experience has indicated that the residence time will exceed 30 minutes. 


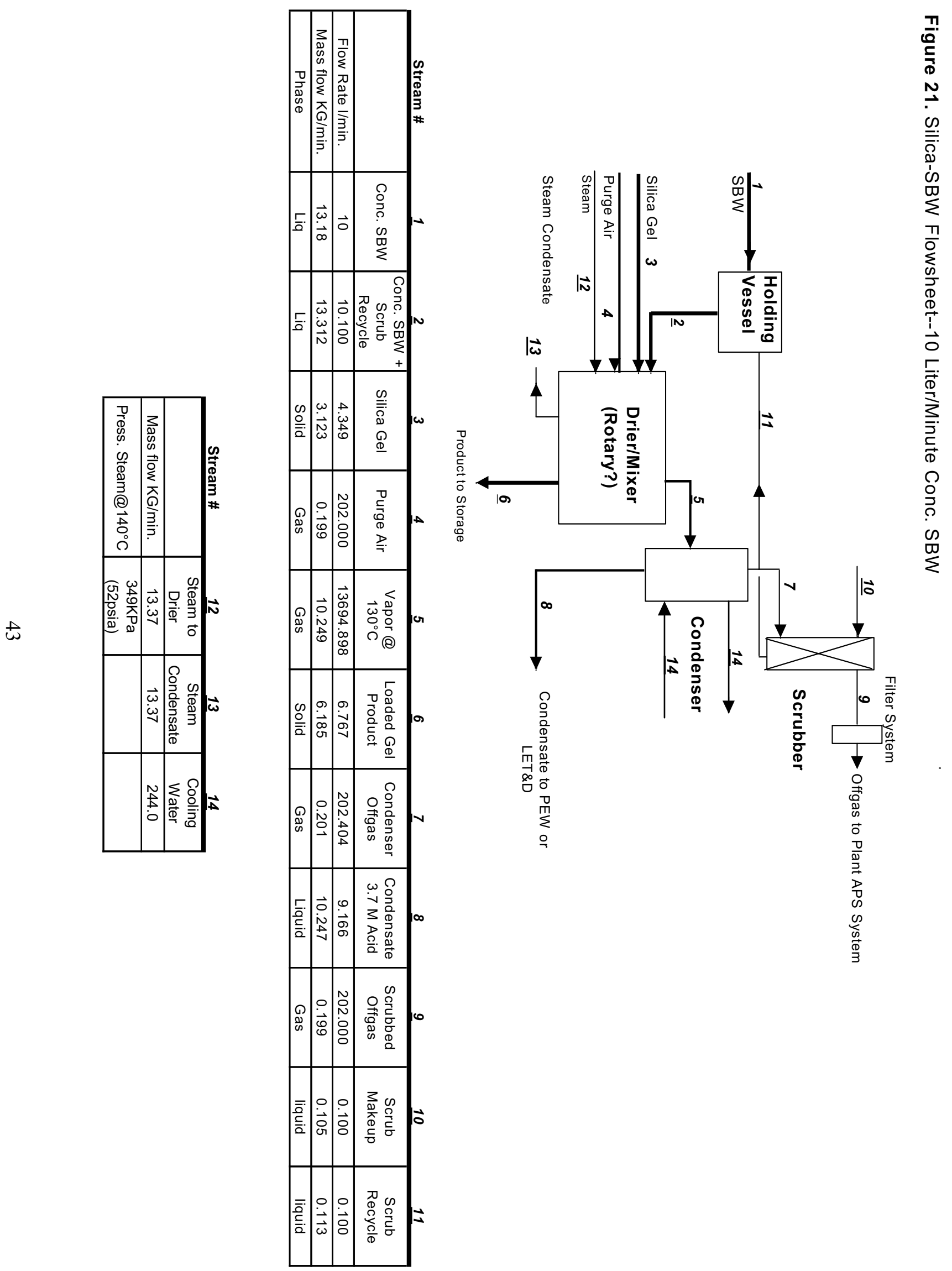




\subsection{CONCLUSIONS AND RECOMENDATIONS}

From the experimental data and literature studied, the silica gel drying process could have a practical use for the treatment, or as a step in the treatment, of several INEEL liquid wastes.

Desirable features found are the ability to:

1. Dry the liquid easily,

2. Remove the acidity without producing a syrupy liquid,

3. Remove a good fraction of the nitrate,

4. Produce a dry flowable and storable solid.

All of the above are accomplished at a reasonable temperature with some volume reduction even with a very concentrated solution.

The product can be processed into an excellent glass with a good volume reduction. This process should definitely be considered as a pretreatment to a glass melting process or any process that will produce the final waste form. It eliminates the complications to design and operation caused by acid gases and water at high temperatures. Alternatively, the silica gel process could solidify the liquid wastes for transport to another site for final processing.

Several questions have surfaced while conducting this study and need to be answered before design work:

1. The kinetics of the sorption and evaporation processes are needed so that a proper mixer drier can be designed.

2. Long range stability of the product is not known. At what overall waste loadings and humidity will the products maintain their flowability?

3. Are there better gel materials or combination gels that can perform better and produce a less leachable product? The few trials made with other materials were very disappointing. Additional material studies are needed to optimize the process.

\section{ACID BOND A660 AND XORB ABSORBENT TESTS}

Two prospective absorbents NoChar's Acid-Bond A660 and XORB's amorphous silicate glass foam were evaluated for absorbing or solidifying newly generated liquid waste (NGLW) and sodiumbearing waste following cesium ion exchange (CsIX-TRU). The solidification tests specifically looked at 1) waste loading, 2) ability to pass the TCLP test, 3) ability of the waste form to pass freeze/thaw test, and 4) stability of the waste form with nitric acid in the simulants over time. Lab tests used two nonradioactive liquid waste simulates NGLW-2000R1 and CsIX-TRU. The NGLW-2000R1 (Table 20) simulate represents NGLW that has been concentrated 500:1 through the Process Equipment Waste Evaporator (PEWE). The CSIX-TRU simulant (Table 21) represents Tank Farm waste that has been 
concentrated 2:1 through the High Level Liquid Waste Evaporator (HLLWE). These are the same simulants used by the Alternative Calcination and Waste Form Development Group in their tests.

Waste loading was determined by stepwise addition of Acid-Bond A660 or XORB solidification agent to $50 \mathrm{ml}$ of NGLW-2000R1 or CSIX-TRU simulant. Waste loading was determined at the point where no remaining free liquid was observed. The waste loading results were used to determine how much solidification agent was required to solidify $150 \mathrm{ml}$ of simulant for use in additional testing. Additional testing consisted of the following:

1. A TCLP test with a $10 \mathrm{~g}$ sample freshly solidified simulant in $200 \mathrm{ml}$ of TCLP extract to determine if the absorbent will retain the RCRA characteristic metals.

2. A freeze/thaw test with a $50 \mathrm{~g}$ sample of solidified simulant. The solidified waste was subjected to 30 freeze/thaw cycles of the following:

a) Ramp temperature to $60^{\circ} \mathrm{C}$ in 15 minutes

b) Maintain $60^{\circ} \mathrm{C}$ for 2 hours

c) Ramp temperature to $20^{\circ} \mathrm{C}$ in 15 minutes

d) Maintain $20^{\circ} \mathrm{C}$ for 1 hour

e) Ramp temperature to $-40^{\circ} \mathrm{C}$ in 15 minutes

f) Maintain $-40^{\circ} \mathrm{C}$ for 2 hours

g) Ramp temperature to $20^{\circ} \mathrm{C}$ in 15 minutes

h) Maintain $20^{\circ} \mathrm{C}$ for 1 hour

A TCLP test with a $10 \mathrm{~g}$ sample from the freeze/thaw test described above in $200 \mathrm{ml}$ of TCLP extract to determine if the freeze/thaw test effected the absorbent's ability to retain RCRA characteristic metals. In addition, any liquid released during the freeze/thaw test would also be tested for RCRA metals.

3. A TCLP test with a $10 \mathrm{~g}$ sample of solidified simulant (aged 41 days) in $200 \mathrm{ml}$ of TCLP extract to determine if aged absorbent can retain RCRA characteristic metals. In addition, any liquid released as the absorbent aged was also tested for TCLP metals.

Absorbent testing was conducted over a two-month period. Waste loading and TCLP test results for freshly solidified, freeze/thaw, and aged samples, will be discussed in more detail below. 
Table 20. NGLW-2000R1: Newly Generated Liquid Waste Simulant Formulation

\begin{tabular}{|c|c|c|c|c|c|}
\hline $\begin{array}{l}\text { Desired } \\
\text { Species }\end{array}$ & $\begin{array}{l}\text { Stock } \\
\text { Molarity } \\
\end{array}$ & $\begin{array}{l}\text { Molecular } \\
\text { Chemical }\end{array}$ & $\begin{array}{l}1 \text { L Batch } \\
\text { Weight }\end{array}$ & Amou & \\
\hline $\mathrm{H}$ & $1.57 \mathrm{E}+00$ & All Acids & & ---- & '---- \\
\hline $\mathrm{Ag}$ & $2.00 \mathrm{E}-05$ & $\mathrm{AgNO}_{3}$ & 169.87 & 3.4 & $\mathrm{mg}$ \\
\hline $\mathrm{Al}$ & $1.70 \mathrm{E}-01$ & $2.2 M \mathrm{Al}\left(\mathrm{NO}_{3}\right)_{3}$ & & 77 & $\mathrm{ml}$ \\
\hline As & ------ & $\mathrm{As}_{2} \mathrm{O}_{5}$ & 229.84 & ----- & $\mathrm{mg}$ \\
\hline B & ------ & $\mathrm{H}_{3} \mathrm{BO}_{3}$ & 61.832 & ----- & $\mathrm{g}$ \\
\hline $\mathrm{Ba}$ & $1.70 \mathrm{E}-05$ & $\mathrm{Ba}\left(\mathrm{NO}_{3}\right)_{2}$ & 261.34 & 4.4 & $\mathrm{mg}$ \\
\hline $\mathrm{Ca}$ & $1.30 \mathrm{E}-01$ & $\mathrm{Ca}\left(\mathrm{NO}_{3}\right)_{2}$ & 164.09 & 21.3 & $\mathrm{~g}$ \\
\hline $\mathrm{Cd}$ & $8.90 \mathrm{E}-05$ & $\mathrm{Cd}\left(\mathrm{NO}_{3}\right)_{2} \cdot 4 \mathrm{H}_{2} \mathrm{O}$ & 308.48 & 27.5 & $\mathrm{mg}$ \\
\hline $\mathrm{Cl}$ & $1.00 \mathrm{E}-01$ & $12.0 \mathrm{MHCI}$ & & 8.3 & $\mathrm{ml}$ \\
\hline $\mathrm{Cr}$ & $2.89 \mathrm{E}-04$ & $\mathrm{Cr}\left(\mathrm{NO}_{3}\right)_{3} \cdot 9 \mathrm{H}_{2} \mathrm{O}$ & 400.15 & 115.6 & $\mathrm{mg}$ \\
\hline Cs & ------ & $\mathrm{CsNO}_{3}$ & 194.91 & ----- & $\mathrm{mg}$ \\
\hline $\mathrm{F}$ & $6.50 \mathrm{E}-02$ & $27.6 \mathrm{MHF}$ & & 2.4 & $\mathrm{ml}$ \\
\hline $\mathrm{Fe}$ & $7.70 \mathrm{E}-04$ & $\mathrm{Fe}\left(\mathrm{NO}_{3}\right)_{3} \cdot 9 \mathrm{H}_{2} \mathrm{O}$ & 404.00 & 0.31 & g \\
\hline $\mathrm{Hg}$ & $2.87 \mathrm{E}-03$ & $\mathrm{Hg}\left(\mathrm{NO}_{3}\right)_{2} \cdot \mathrm{H}_{2} \mathrm{O}$ & 342.62 & 983 & $\mathrm{mg}$ \\
\hline K & $3.00 \mathrm{E}-02$ & $\mathrm{KNO}_{3}$ & 101.10 & 3.0 & $\mathrm{~g}$ \\
\hline $\mathrm{Mn}$ & ------ & $\begin{array}{l}\mathrm{Mn}\left(\mathrm{NO}_{3}\right)_{2} \\
{[50 \% \text { soln.] }}\end{array}$ & 178.95 & ----- & g soln \\
\hline Mo & ------ & $\mathrm{H}_{2} \mathrm{MoO}_{4}$ & 161.95 & ----- & $\mathrm{g}$ \\
\hline $\mathrm{Na}$ & $1.65 \mathrm{E}+00$ & $\mathrm{NaNO}_{3}$ & 85.00 & 183 & $\mathrm{~g}$ \\
\hline $\mathrm{Ni}$ & $1.20 \mathrm{E}-04$ & $\mathrm{Ni}\left(\mathrm{NO}_{3}\right)_{2} \cdot 6 \mathrm{H}_{2} \mathrm{O}$ & 290.80 & 34.9 & $\mathrm{mg}$ \\
\hline $\mathrm{NO}_{3}$ & $4.20 \mathrm{E}+00$ & $15.9 \mathrm{MHNO}_{3}$ & & 78.9 & $\mathrm{ml}$ \\
\hline $\mathrm{Pb}$ & $3.86 \mathrm{E}-05$ & $\mathrm{~Pb}\left(\mathrm{NO}_{3}\right)_{2}$ & 331.21 & 12.8 & $\mathrm{mg}$ \\
\hline $\mathrm{PO}_{4}$ & ------ & $14.8 \mathrm{MH}_{3} \mathrm{PO}_{4}$ & & ----- & $\mathrm{ml}$ \\
\hline $\mathrm{Se}$ & ------ & $\mathrm{SeO}_{2}$ & 110.96 & ----- & $\mathrm{mg}$ \\
\hline $\mathrm{Si}$ & $5.3 \mathrm{E}-02$ & $\mathrm{SiO}_{2}$ & 60.08 & 3.2 & $\mathrm{mg}$ \\
\hline $\mathrm{Sr}$ & ------ & $\mathrm{Sr}\left(\mathrm{NO}_{3}\right)_{2}$ & 211.63 & ----- & $\mathrm{mg}$ \\
\hline $\mathrm{SO}_{4}$ & $7.30 \mathrm{E}-02$ & $18.0 \mathrm{MH}_{2} \mathrm{SO}_{4}$ & & 4.1 & $\mathrm{ml}$ \\
\hline $\mathrm{Zr}$ & ------ & $\begin{array}{l}\mathrm{ZrO}\left(\mathrm{NO}_{3}\right)_{2} \cdot 3 \mathrm{H}_{2} \mathrm{O} \\
\text { Actual } \mathrm{NO}_{3}= \\
\mathrm{NO}_{3}=\end{array}$ & $\begin{array}{l}285.27 \\
4.21 \mathrm{M} \\
273.54 \mathrm{~g}\end{array}$ & ----- & g \\
\hline
\end{tabular}

Note: Projected waste from 603 and HLLWE for 2000 to 2003. 
Table 21. CsIX-TRU: Cesium Ion Exchange Sodium-Bearing Waste Simulant Formulation

\begin{tabular}{|c|c|c|c|c|c|}
\hline $\begin{array}{l}\text { Desired } \\
\text { Species }\end{array}$ & $\begin{array}{l}\text { Stock } \\
\text { Molarity } \\
\end{array}$ & $\begin{array}{l}\text { Molecular } \\
\text { Chemical }\end{array}$ & $\begin{array}{l}1 \text { L Batch } \\
\text { Weight }\end{array}$ & \multicolumn{2}{|c|}{ Amount } \\
\hline $\mathrm{H}$ & $1.57 \mathrm{E}+00$ & All Acids & & ---- & ----- \\
\hline $\mathrm{Ag}$ & $2.75 \mathrm{E}-05$ & $\mathrm{AgNO}_{3}$ & 169.87 & 4.67 & $\mathrm{mg}$ \\
\hline $\mathrm{Al}$ & $7.84 \mathrm{E}-01$ & $2.2 M \mathrm{Al}\left(\mathrm{NO}_{3}\right)_{3}$ & & 356.4 & $\mathrm{ml}$ \\
\hline As & $6.07 \mathrm{E}-05$ & $\mathrm{As}_{2} \mathrm{O}_{5}$ & 229.84 & 6.98 & $\mathrm{mg}$ \\
\hline B & $1.91 \mathrm{E}-02$ & $\mathrm{H}_{3} \mathrm{BO}_{3}$ & 61.832 & 1.181 & $\mathrm{~g}$ \\
\hline $\mathrm{Ba}$ & $7.23 \mathrm{E}-05$ & $\mathrm{Ba}\left(\mathrm{NO}_{3}\right)_{2}$ & 261.34 & 18.89 & $\mathrm{mg}$ \\
\hline $\mathrm{Ca}$ & $5.76 \mathrm{E}-02$ & $\mathrm{Ca}\left(\mathrm{NO}_{3}\right)_{2}$ & 164.09 & 9.45 & $\mathrm{~g}$ \\
\hline $\mathrm{Cd}$ & $3.32 \mathrm{E}-03$ & $\mathrm{Cd}\left(\mathrm{NO}_{3}\right)_{2} \bullet 4 \mathrm{H}_{2} \mathrm{O}$ & 308.48 & 1.024 & $\mathrm{~g}$ \\
\hline $\mathrm{Cl}$ & $4.05 \mathrm{E}-02$ & $12.0 \mathrm{MHCI}$ & & 3.38 & $\mathrm{ml}$ \\
\hline $\mathrm{Cr}$ & $4.78 \mathrm{E}-03$ & $\mathrm{Cr}\left(\mathrm{NO}_{3}\right)_{3} \cdot 9 \mathrm{H}_{2} \mathrm{O}$ & 400.15 & 1.913 & $\mathrm{~g}$ \\
\hline Cs & ------ & $\mathrm{CsNO}_{3}$ & 194.91 & ----- & $\mathrm{mg}$ \\
\hline $\mathrm{F}$ & $7.12 \mathrm{E}-02$ & $27.6 \mathrm{MHF}$ & & 2.58 & $\mathrm{ml}$ \\
\hline $\mathrm{Fe}$ & $2.71 \mathrm{E}-02$ & $\mathrm{Fe}\left(\mathrm{NO}_{3}\right)_{3} \cdot 9 \mathrm{H}_{2} \mathrm{O}$ & 404.00 & 10.95 & $\mathrm{~g}$ \\
\hline $\mathrm{Hg}$ & $1.60 \mathrm{E}-03$ & $\mathrm{Hg}\left(\mathrm{NO}_{3}\right)_{2} \cdot \mathrm{H}_{2} \mathrm{O}$ & 342.62 & 0.548 & $\mathrm{~g}$ \\
\hline K & $2.45 \mathrm{E}-01$ & $\mathrm{KNO}_{3}$ & 101.10 & 24.8 & $\mathrm{~g}$ \\
\hline $\mathrm{Mn}$ & $1.59 \mathrm{E}-02$ & $\begin{array}{l}\mathrm{Mn}\left(\mathrm{NO}_{3}\right)_{2} \\
{[50 \% \text { soln.] }}\end{array}$ & 178.95 & 5.69 & g soln \\
\hline Mo & $8.43 \mathrm{E}-04$ & $\mathrm{H}_{2} \mathrm{MoO}_{4}$ & 161.95 & 0.1365 & $\mathrm{~g}$ \\
\hline $\mathrm{Na}$ & $2.36 \mathrm{E}+00$ & $\mathrm{NaNO}_{3}$ & 85.00 & 200.6 & $\mathrm{~g}$ \\
\hline $\mathrm{Ni}$ & $2.27 \mathrm{E}-03$ & $\mathrm{Ni}\left(\mathrm{NO}_{3}\right)_{2} \cdot 6 \mathrm{H}_{2} \mathrm{O}$ & 290.80 & 0.660 & $\mathrm{~g}$ \\
\hline $\mathrm{NO}_{3}$ & $6.95 \mathrm{E}+00$ & $15.9 \mathrm{MHNO}_{3}$ & & 99.4 & $\mathrm{ml}$ \\
\hline $\mathrm{Pb}$ & $2.01 \mathrm{E}-03$ & $\mathrm{~Pb}\left(\mathrm{NO}_{3}\right)_{2}$ & 331.21 & 0.666 & $\mathrm{~g}$ \\
\hline $\mathrm{PO}_{4}$ & $2.04 \mathrm{E}-02$ & $14.8 \mathrm{MH}_{3} \mathrm{PO}_{4}$ & & 1.378 & $\mathrm{ml}$ \\
\hline $\mathrm{Se}$ & $3.20 \mathrm{E}-05$ & $\mathrm{SeO}_{2}$ & 110.96 & 3.551 & $\mathrm{mg}$ \\
\hline $\mathrm{Sr}$ & $2.04 \mathrm{E}-05$ & $\mathrm{Sr}\left(\mathrm{NO}_{3}\right)_{2}$ & 211.63 & 4.32 & $\mathrm{mg}$ \\
\hline $\mathrm{SO}_{4}$ & $6.37 \mathrm{E}-02$ & $18.0 \mathrm{MH}_{2} \mathrm{SO}_{4}$ & & 3.54 & $\mathrm{ml}$ \\
\hline $\mathrm{Zr}$ & $7.31 \mathrm{E}-03$ & $\mathrm{ZrO}\left(\mathrm{NO}_{3}\right)_{2} \cdot 3 \mathrm{H}_{2} \mathrm{O}$ & 285.27 & 2.085 & $\mathrm{~g}$ \\
\hline & & Actual $\mathrm{NO}_{3}=$ & $6.81 M$ & & \\
\hline & & $\mathrm{NO}_{3}=$ & $422.48 \mathrm{~g}$ & & \\
\hline
\end{tabular}

Note: Tank Farm SBW following concentration in the HLLW Evaporator \& after Cs removal. (Based on SBWMtlBal.xls spreadsheet by Charles Barnes received on 12/9/98.)

\subsection{Waste Loading}

Both absorbents exhibited good waste loadings. The tests indicate waste loading of 80 to 86 $\mathrm{Wt} \%$ is achievable with Acid-Bond 660 with a volume increase of about $10 \%$. A waste loading of 78 to $80 \mathrm{Wt} \%$ is achievable with XORB with a volume increase of about $50 \%$. Even though the waste loadings for the two absorbents were both high, XORB was much more difficult to set up. When XORB was first added to the simulant it would soak up the liquid and look like a wet sand. However, as the mixture was stirred, the XORB absorbent would compact and free liquid was observed requiring additional absorbent to be added until finally no more free liquids were observed. At the point where no more free liquid was 
observed a dry absorbent volume ten times higher than the amount of simulant being absorbed had been required.

\subsection{TCLP Test Results}

The TCLP and liquid RCRA metal analytical test results are shown in Table 22. These results will be discussed in more detail below.

\subsubsection{NGLW-2000R1 in Acid-Bond 660}

The TCLP results for fresh, freeze/thaw and aged tests for NGLW-2000R1 in Acid Bond 660 are show in Figure 22. The maximum expected concentration was estimated based on $10 \mathrm{ml}$ of NGLW2000R 1 simulant in $200 \mathrm{ml}$ of TCLP extract. Initially the absorbent performed fairly well in retaining the RCRA characteristic metals. The fresh absorbent was able to remove $98.7 \%$ of the chromium (from an expected $5.50 \mathrm{ug} / \mathrm{ml}$ to below $0.07 \mathrm{ug} / \mathrm{ml}$ ), $76.1 \%$ of the cadmium (from an expected $1.31 \mathrm{ug} / \mathrm{ml}$ to 0.31 $\mathrm{ug} / \mathrm{ml}$ ), $58.1 \%$ of the mercury (from an expected $46.8 \mathrm{ug} / \mathrm{ml}$ to $19.6 \mathrm{ug} / \mathrm{ml}$ ), and over $47.0 \%$ of the lead (from an expected $0.61 \mathrm{ug} / \mathrm{ml}$ to below $0.32 \mathrm{ug} / \mathrm{ml}$ ). This met all of the RCRA characteristic metal requirements with the exception of mercury.

Even though all of the tests were able to pass TCLP for cadmium, chromium, and lead non of the tests were able to pass for mercury (see table 3). In general the concentration of the RCRA characteristic metals in the TCLP extract for the aged and freeze/thaw tests were less than those shown for the freshly absorbed samples. However, the absorbent released liquid during the freeze/thaw and aging tests. This liquid failed when tested for the four RCRA characteristic metals tracked in these experiments indicating that Acid-Bond 660 would not work for solidifying NGLW.

Figure 22. Comparison of TCLP test results for freshly absorbed, freeze/thaw (covered and uncovered), and aged tests for NGLW-2000R1 simulant in Acid Bond 660 absorbent.

TCLP Results for NGLW-2000R1 in Acid-Bond 660

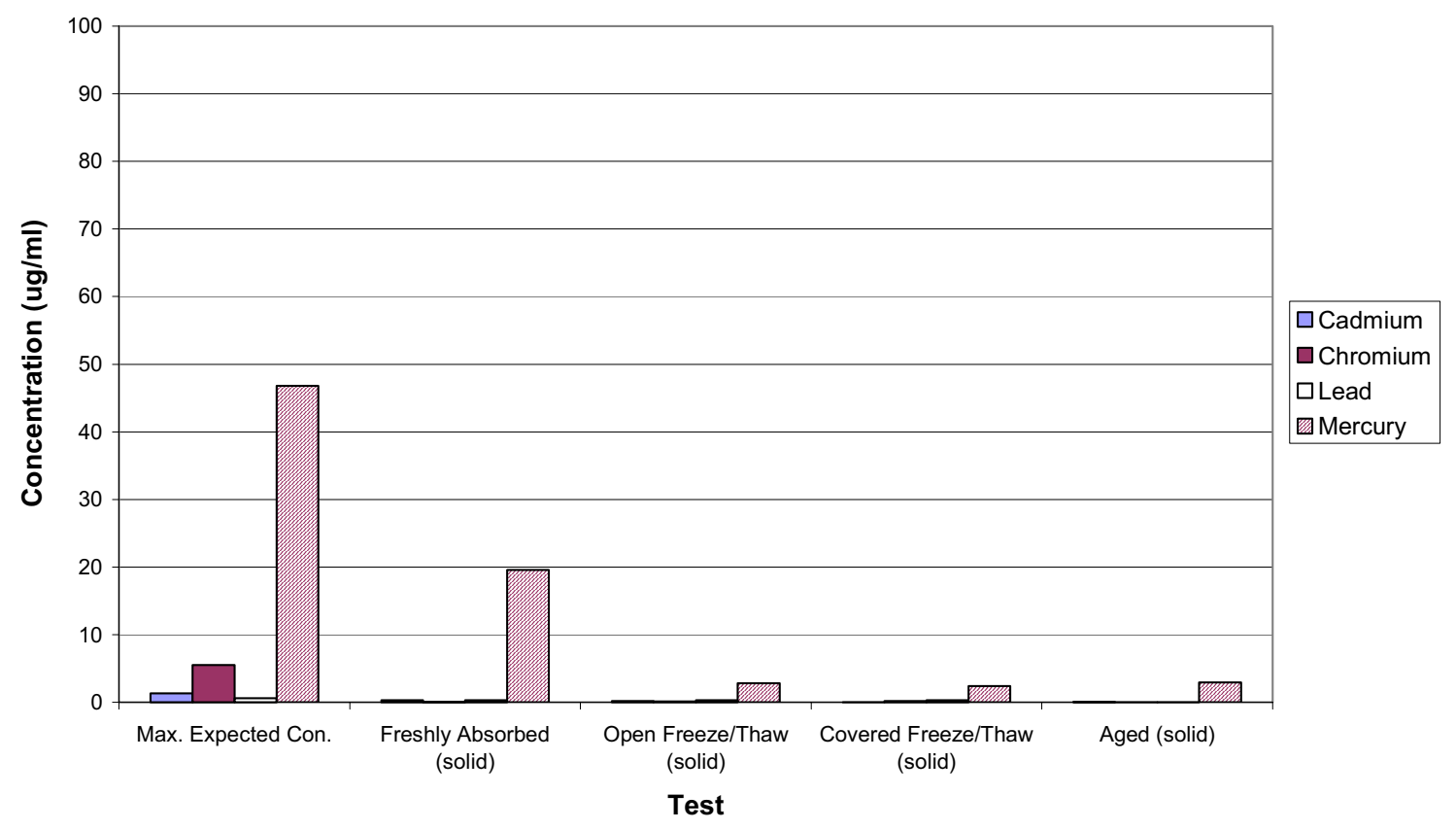


Table 22. Absorbent Test Analytical Results

\begin{tabular}{|c|c|c|c|c|c|}
\hline \multirow[b]{2}{*}{ Matrix } & \multirow[b]{2}{*}{ Description } & \multicolumn{4}{|c|}{ Concentration (ug/ml) } \\
\hline & & Cadmium & Chromium & Lead & Mercury \\
\hline \begin{tabular}{|l|} 
Max Conc \\
(estimate)
\end{tabular} & $\begin{array}{l}1 \mathrm{ml} \text { NGLW-2000R1 in } \\
200 \mathrm{ml} \text { TCLP extract. }\end{array}$ & $1.31 \mathrm{E}+00$ & $5.50 \mathrm{E}+00$ & $6.10 \mathrm{E}-01$ & $4.68 \mathrm{E}+01$ \\
\hline \multirow{6}{*}{ 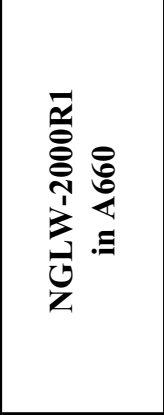 } & Freshly Absorbed (solid) & $3.13 \mathrm{E}-01$ & $<7.07 \mathrm{E}-02 *$ & $<3.23 \mathrm{E}-01 *$ & $1.96 \mathrm{E}+01$ \\
\hline & Open Freeze/Thaw (solid) & $2.22 \mathrm{E}-01$ & $1.01 \mathrm{E}-01$ & $<3.23 \mathrm{E}-01 *$ & $2.82 \mathrm{E}+00$ \\
\hline & Covered Freeze/Thaw (solid) & $<5.05 \mathrm{E}-02 *$ & $1.92 \mathrm{E}-01$ & $<3.23 \mathrm{E}-01 *$ & $2.43 \mathrm{E}+00$ \\
\hline & Covered Freeze/Thaw (liquid) & $1.72 \mathrm{E}+01$ & $2.48 \mathrm{E}+01$ & $1.36 \mathrm{E}+01$ & $7.16 \mathrm{E}+02$ \\
\hline & Aged (solid) & $8.52 \mathrm{E}-02$ & $2.00 \mathrm{E}-02$ & $2.56 \mathrm{E}-02$ & $2.96 \mathrm{E}+00$ \\
\hline & Aged (liquid) & $9.78 \mathrm{E}+00$ & $1.58 \mathrm{E}+01$ & $6.48 \mathrm{E}+00$ & $5.27 \mathrm{E}+02$ \\
\hline \multirow{4}{*}{ 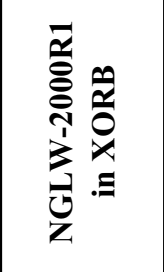 } & Freshly Absorbed (solid) & $2.83 \mathrm{E}-01$ & $6.67 \mathrm{E}-01$ & $<3.23 \mathrm{E}-01 *$ & $2.00 \mathrm{E}+01$ \\
\hline & Open Freeze/Thaw (solid) & $8.69 \mathrm{E}-01$ & $3.19 \mathrm{E}+00$ & $5.76 \mathrm{E}-01$ & $3.75 \mathrm{E}+01$ \\
\hline & Covered Freeze/Thaw (solid) & $7.68 \mathrm{E}-01$ & $2.02 \mathrm{E}+00$ & $4.75 \mathrm{E}-01$ & $3.95 \mathrm{E}+01$ \\
\hline & Aged (solid) & $3.42 \mathrm{E}-01$ & $7.86 \mathrm{E}-01$ & $2.57 \mathrm{E}-01$ & $2.00 \mathrm{E}+01$ \\
\hline \begin{tabular}{|l|} 
Max Conc \\
(estimate)
\end{tabular} & $\begin{array}{l}1 \mathrm{ml} \mathrm{Cs}-1 \mathrm{X}-\mathrm{TRU} \text { in } \\
200 \mathrm{ml} \text { TCLP extract. }\end{array}$ & $4.88 \mathrm{E}+01$ & $9.11 \mathrm{E}+01$ & $3.17 \mathrm{E}+01$ & $2.61 \mathrm{E}+01$ \\
\hline \multirow{6}{*}{ 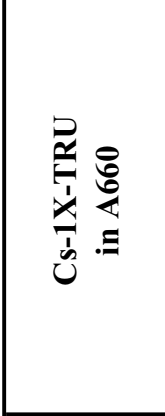 } & Freshly Absorbed (solid) & $1.16 \mathrm{E}+01$ & $4.80 \mathrm{E}+00$ & $3.62 \mathrm{E}+00$ & $7.40 \mathrm{E}+00$ \\
\hline & Open Freeze/Thaw (solid) & $2.00 \mathrm{E}+01$ & $5.96 \mathrm{E}-01$ & $6.67 \mathrm{E}+00$ & $1.43 \mathrm{E}+00$ \\
\hline & Covered Freeze/Thaw (solid) & $1.09 \mathrm{E}+01$ & $2.21 \mathrm{E}+00$ & $2.06 \mathrm{E}+00$ & $2.06 \mathrm{E}+00$ \\
\hline & Covered Freeze/Thaw (liquid) & $6.46 \mathrm{E}+02$ & $1.60 \mathrm{E}+02$ & $7.62 \mathrm{E}+02$ & $8.08 \mathrm{E}+01$ \\
\hline & Aged (solid) & $4.75 \mathrm{E}+00$ & $4.68 \mathrm{E}+00$ & 7.24E-01 & $2.54 \mathrm{E}+00$ \\
\hline & Aged (liquid) & $2.98 \mathrm{E}+02$ & $2.13 \mathrm{E}+02$ & $3.60 \mathrm{E}+02$ & $1.87 \mathrm{E}+02$ \\
\hline \multirow{4}{*}{ 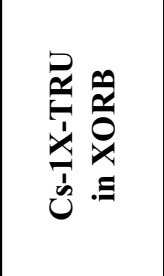 } & Freshly Absorbed (solid) & $8.26 \mathrm{E}+00$ & $6.07 \mathrm{E}+00$ & $2.19 \mathrm{E}+00$ & $8.10 \mathrm{E}+00$ \\
\hline & Open Freeze/Thaw (solid) & $1.55 \mathrm{E}+01$ & $1.04 \mathrm{E}+01$ & $6.21 \mathrm{E}+00$ & $8.51 \mathrm{E}+00$ \\
\hline & Covered Freeze/Thaw (solid) & $1.79 \mathrm{E}+01$ & $1.19 \mathrm{E}+01$ & $4.19 \mathrm{E}+00$ & $1.15 \mathrm{E}+01$ \\
\hline & Aged (solid) & $1.10 \mathrm{E}+01$ & $7.72 \mathrm{E}+00$ & $3.63 \mathrm{E}+00$ & $8.54 \mathrm{E}+00$ \\
\hline \multirow{4}{*}{ 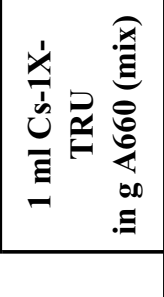 } & Covered Freeze/Thaw (mixture) & $2.86 \mathrm{E}+00$ & $<7.07 \mathrm{E}-02^{*}$ & $<3.23 \mathrm{E}-01 *$ & $1.25 \mathrm{E}+00$ \\
\hline & Covered Freeze/Thaw (brown solid) & $1.89 \mathrm{E}+01$ & $3.23 \mathrm{E}-01$ & $<3.23 \mathrm{E}-01 *$ & $1.14 \mathrm{E}+00$ \\
\hline & Covered Freeze/Thaw (pink solid) & \multicolumn{4}{|c|}{ Not analyzed: Solidified the TCLP extract } \\
\hline & TCLP Limits: & $1.00 \mathrm{E}+00$ & $5.00 \mathrm{E}+00$ & $5.00 \mathrm{E}+00$ & $2.00 \mathrm{E}-01$ \\
\hline
\end{tabular}

Note: *Below detection limits - values shown are threshold values.

Shaded areas of chart represent areas where the tests failed RCRA analysis. 


\subsubsection{CsIX-TRU in Acid-Bond 660}

The TCLP results for fresh, freeze/thaw and aged tests for CsIX-TRU in Acid Bond 660 are show in Figure 23. The maximum expected concentration was estimated based on $10 \mathrm{ml}$ of CsIX-TRU simulant in $200 \mathrm{ml}$ of TCLP extract. Again Acid-Bond 660 performed fairly well in retaining the RCRA characteristic metals. The fresh absorbent was able to remove $94.7 \%$ of the chromium (from an expected $91.1 \mathrm{ug} / \mathrm{ml}$ to $4.80 \mathrm{ug} / \mathrm{ml}$ ), $88.6 \%$ of the lead (from an expected $31.7 \mathrm{ug} / \mathrm{ml}$ to $3.62 \mathrm{ug} / \mathrm{ml}$ ), $76.2 \%$ of the cadmium (from an expected $48.8 \mathrm{ug} / \mathrm{ml}$ to $11.6 \mathrm{ug} / \mathrm{ml}$ ), and $71.6 \%$ of the mercury (from an expected 26.1 $\mathrm{ug} / \mathrm{ml}$ to $7.40 \mathrm{ug} / \mathrm{ml}$ ). Even though the absorbent was able to retain a significant amount of the RCRA characteristic metals it still failed for mercury and cadmium. Again the absorbent liberated liquid during freeze/thaw and age testing that was not able to pass for any of the four RCRA metals used in these tests (see Table 3 above) indicating that this absorbent would not work for solidifying SBW.

Figure 23. Comparison of TCLP test results for freshly absorbed, freeze/thaw (covered and uncovered), and aged tests for CsIX-TRU simulant in Acid Bond 660 absorbent.

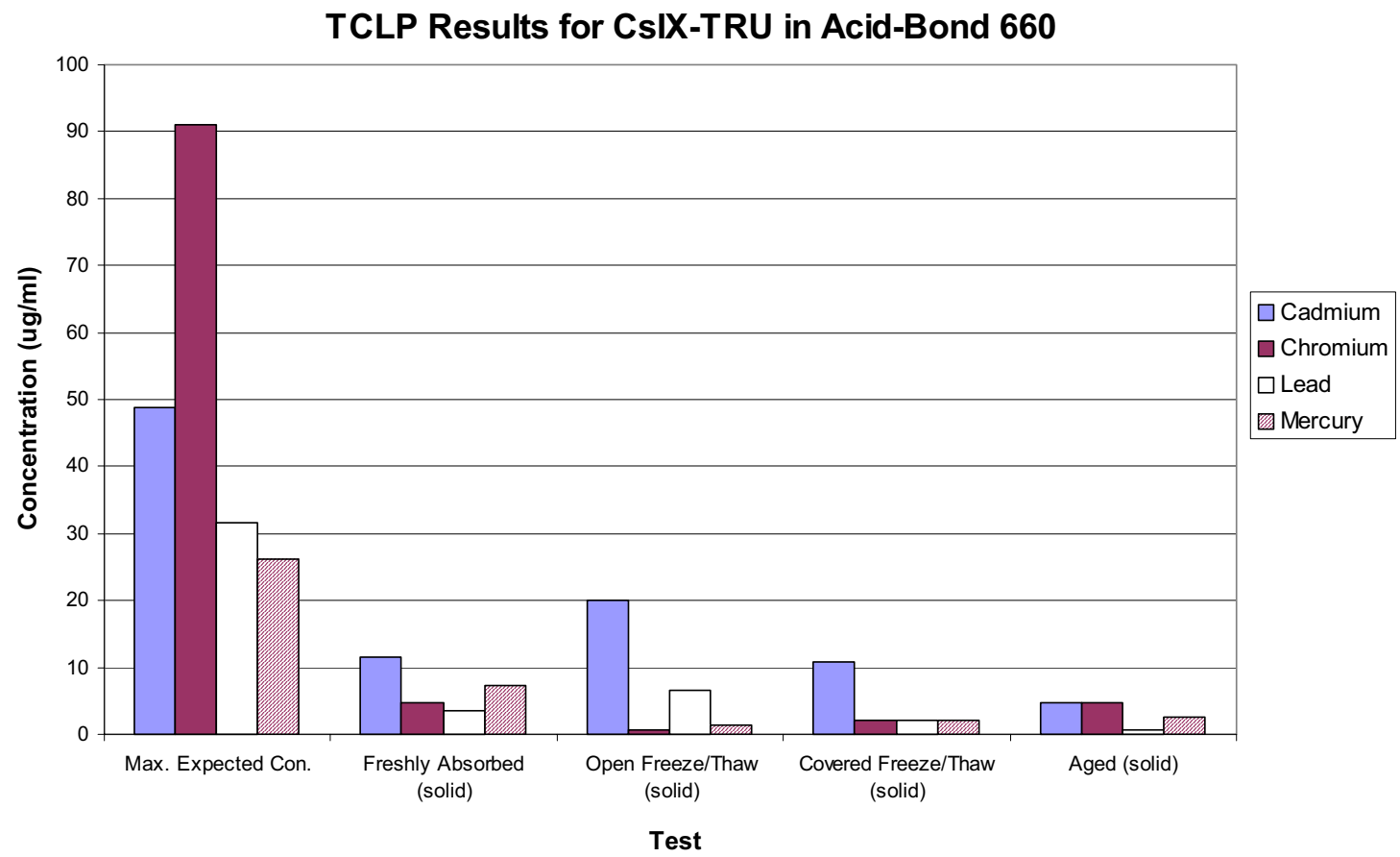

An additional freeze/thaw test was conducted using a higher Acid-Bond 660 to CsIX-TRU simulant ratio (1g A660:1 $\mathrm{ml} \mathrm{CsIX-TRU} \mathrm{versus} \mathrm{3g} \mathrm{A660:4ml} \mathrm{CsIX-TRU)} \mathrm{to} \mathrm{see} \mathrm{if} \mathrm{the} \mathrm{liquid} \mathrm{could} \mathrm{be}$ kept within the absorbent during the freeze/thaw and aging tests (see Figure 4). The test resulted in the formation of three different strata of Acid-Bond 660. The top layer was the typical brown color seen in the previous tests indicating that the absorbent had undergone some reaction with the nitric acid. The bottom layer was pink indicating that it had absorbed the liquid that had been liberated from the upper layer during the freeze/thaw test. The thin middle layer was white which is the original color of the absorbent indicating that it was basically the same as the original absorbent material. Only a mixed layer (brown, white and pink) and the brown layer TCLP results are shown in Figure 24. The white layer was too thin to sample and the pink layer caused the TCLP extract to solidify. As a mixture the higher absorbent ratio performed better than the former tests that used a lower absorbent to simulant ratio 
resulting in increased retention of RCRA characteristic metals. Retention increased from $94.7 \%$ to over $99.9 \%$ for chromium, from $88.6 \%$ to over $99.0 \%$ for the lead, from $76.2 \%$ to $94.1 \%$ for the cadmium, and from $71.6 \%$ to $95.2 \%$ for the mercury. However, the TCLP extract still failed for mercury and cadmium indicating that this absorbent would not work for solidifying SBW.

Figure 24. The effect of increasing the Acid-Bond 660 absorbent to CsIX-TRU simulant ratio on TCLP test results for covered freeze/thaw tests.

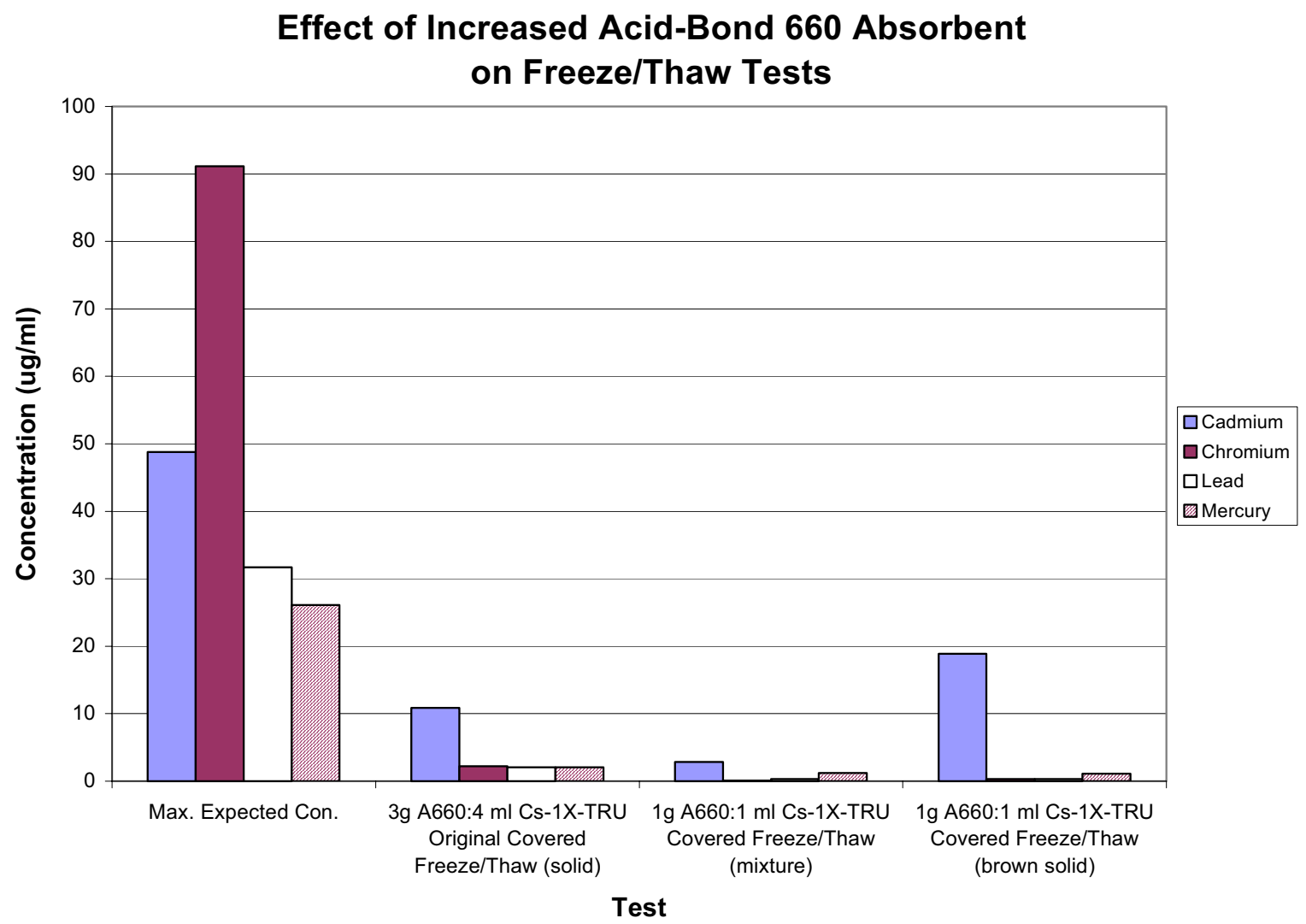

Comparison of the freshly absorbed and aged test results indicates that the Acid-Bond 660 is degrading over time. We were told by the vendor that Acid-Bond 660 is and inorganic polymer (we assumed it to be a silica based polymer). It was initially hoped that the Acid-Bond would adequately absorbed water, then be amenable for vitrification so the waste could be vitrified at a large savings in treatment and disposal costs. A small $<1 \mathrm{~g}$ sample of the waste was placed in a planchette on a hot plate to ensure to determine if any undesirable reactions would occur during vitrification. We observed the solidified SBW would sustain "filament burning" after the polymer dried out. This reaction was not observed when Acid-Bond 660 was heated by itself on the hot plate. This is further indication that AcidBond 660 undergoes some type of reaction with the nitric acid in the simulated waste. Upon further investigation the supplier identified Acid-Bond 660 as an polyacrylate (organic based) polymer. 


\subsubsection{NGLW-2000R1 in XORB}

The TCLP results for fresh, freeze/thaw and aged tests for NGLW-2000R1 in XORB are show in Figure 25. The maximum expected concentration was estimated based on $10 \mathrm{ml}$ of NGLW-2000R1 simulant in $200 \mathrm{ml}$ of TCLP extract. The XORB absorbent was able to remove some of the RCRA characteristic metals but was not as good as the Acid-Bond 660. The fresh XORB absorbent was able to remove $87.9 \%$ of the chromium (from an expected $5.50 \mathrm{ug} / \mathrm{ml}$ to $0.67 \mathrm{ug} / \mathrm{ml}$ ), $78.4 \%$ of the cadmium (from an expected $1.31 \mathrm{ug} / \mathrm{ml}$ to $0.28 \mathrm{ug} / \mathrm{ml}$ ), $57.3 \%$ of the mercury (from an expected $46.8 \mathrm{ug} / \mathrm{ml}$ to 20.0 $\mathrm{ug} / \mathrm{ml}$ ), and over $47.0 \%$ of the lead (from an expected $0.61 \mathrm{ug} / \mathrm{ml}$ to below $0.32 \mathrm{ug} / \mathrm{ml}$ ). XORB was unable to meet the RCRA characteristic metal requirements for cadmium and mercury indicating that XORB would not work for solidifying NGLW.

Figure 25. Comparison of TCLP test results for freshly absorbed, freeze/thaw (covered and uncovered), and aged tests for NGLW-2000R1 simulant in XORB absorbent.

TCLP Results for NGLW-2000R1 in XORB

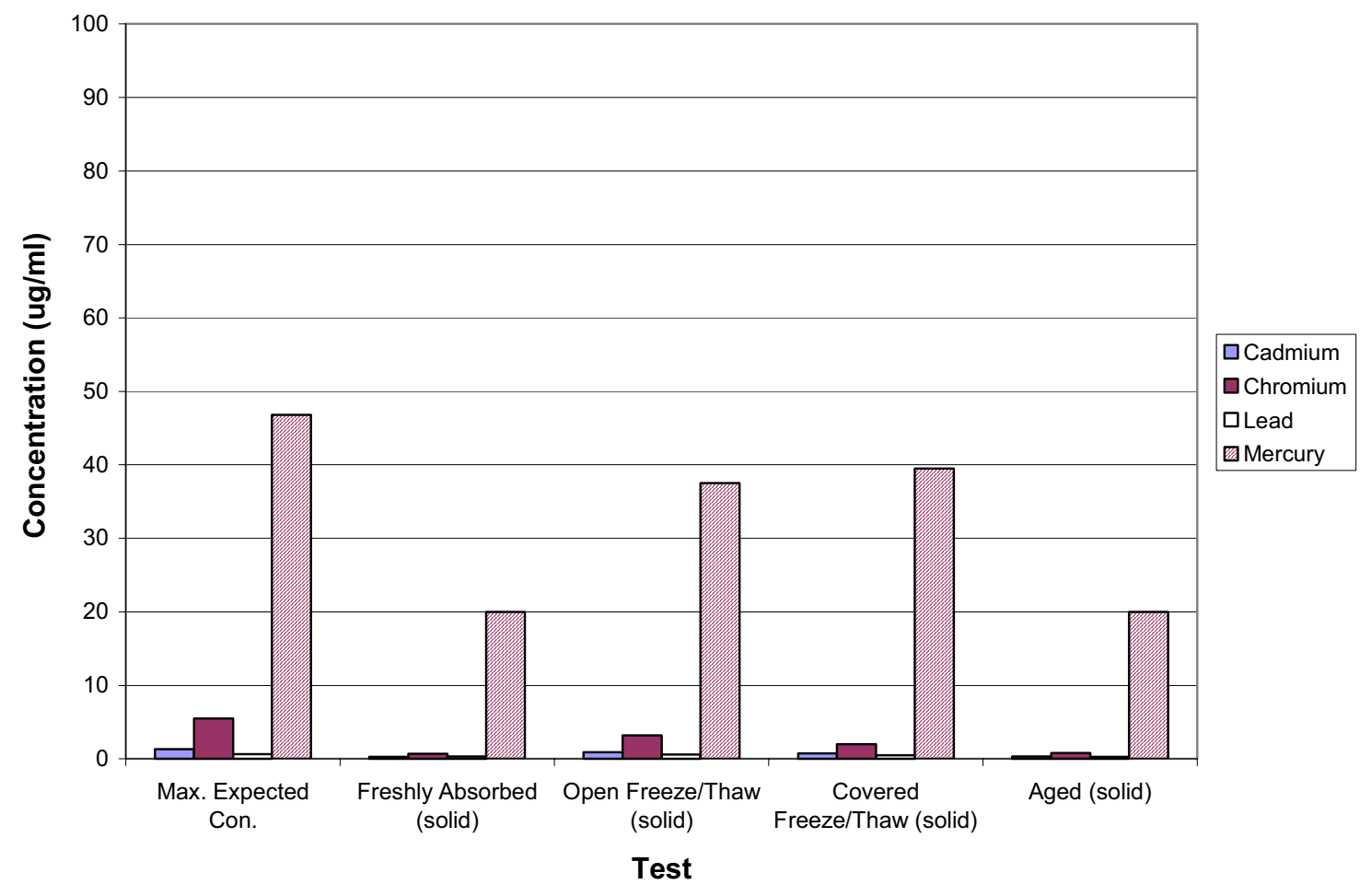

No free liquids were observed for any of the tests. By comparing the freshly absorbed and aged tests it is seen that the absorbent was not effected by aging as was the case for Acid-Bond 660. However, there was a significant loss in XORB absorbent's ability to retain mercury when subjected to freeze/thaw tests. There was little difference between the covered and uncovered freeze thaw tests indicating that this change was unaffected by how much water was driven out of the absorbent during the freeze/thaw process. 


\subsubsection{CsIX-TRU in XORB}

The TCLP results for fresh, freeze/thaw and aged tests for CsIX-TRU in XORB are show in Figure 26. The maximum expected concentration was estimated based on $10 \mathrm{ml}$ of CsIX-TRU simulant in $200 \mathrm{ml}$ of TCLP extract. Again XORB was able to remove some of the RCRA characteristic metals. XORB was better at removing lead and cadmium from CsIX-TRU than was Acid-Bond 660. The fresh absorbent was able to remove $93.3 \%$ of the chromium (from an expected $91.1 \mathrm{ug} / \mathrm{ml}$ to $6.07 \mathrm{ug} / \mathrm{ml}$ ), $93.1 \%$ of the lead (from an expected $31.7 \mathrm{ug} / \mathrm{ml}$ to $2.19 \mathrm{ug} / \mathrm{ml}$ ), $83.1 \%$ of the cadmium (from an expected $48.8 \mathrm{ug} / \mathrm{ml}$ to $8.26 \mathrm{ug} / \mathrm{ml}$ ), and $69.0 \%$ of the mercury (from an expected $26.1 \mathrm{ug} / \mathrm{ml}$ to $8.10 \mathrm{ug} / \mathrm{ml}$ ). Even though the absorbent was able to retain a significant amount of the RCRA characteristic metals it still failed for mercury, cadmium, and chromium indicating that this absorbent would not work for solidifying SBW.

Figure 26. Comparison of TCLP test results for freshly absorbed, freeze/thaw (covered and uncovered), and aged tests for CsIX-TRU simulant in XORB absorbent.

TCLP Results for CsIX-TRU in XORB

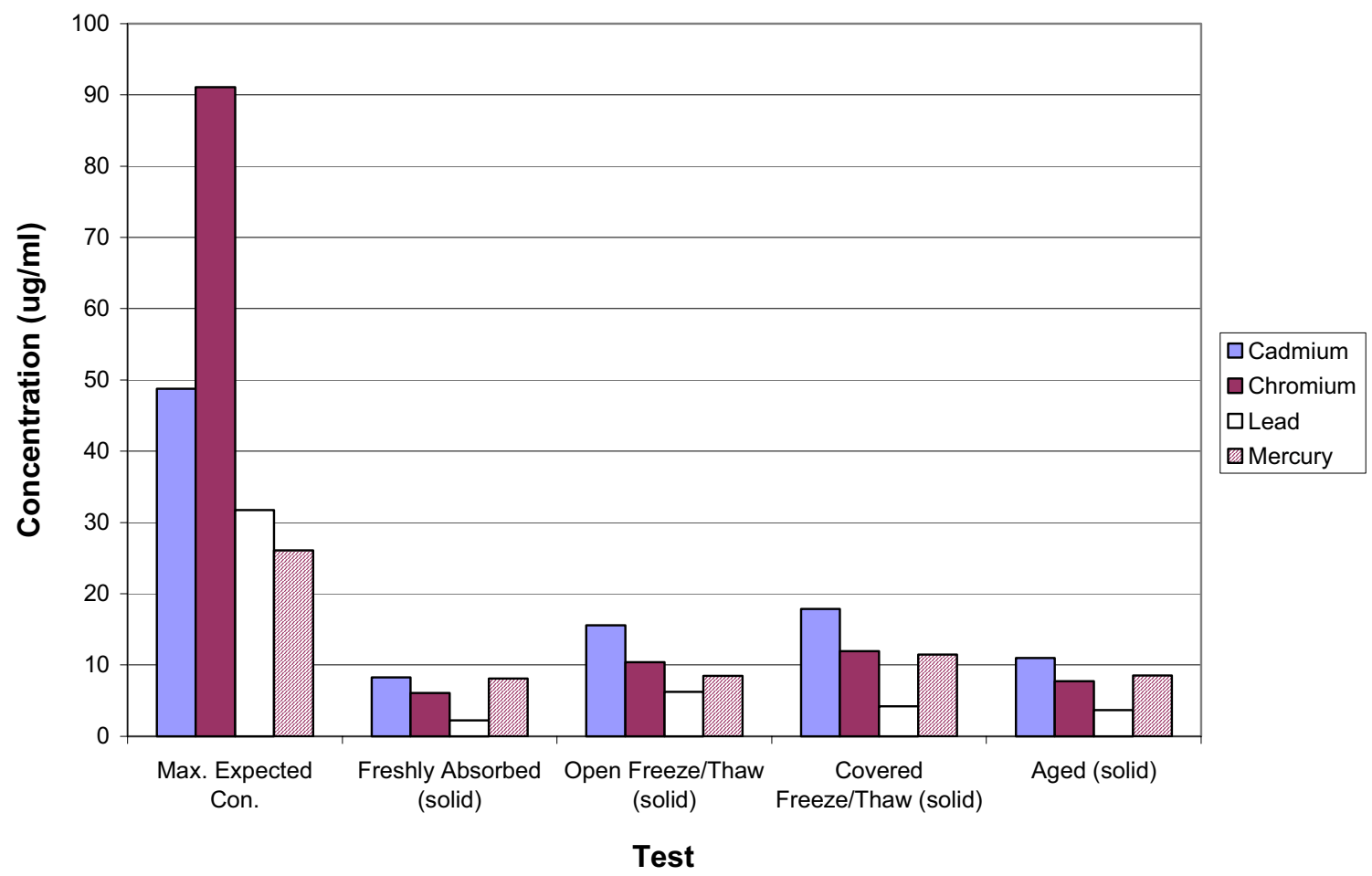

Very similar results are seen in these tests to what was observed when using XORB with NGLW2000R1. No free liquids were liberated liquid while conducting freeze/thaw and age testing. There is little difference between the freshly absorbed and aged tests indicating that the effectiveness of the absorbent does not degrade over time. There was little difference between the covered and uncovered freeze thaw tests indicating that RCRA characteristic metal retention is unaffected by how much water was driven out of the absorbent during the freeze/thaw process. 


\subsection{SUMMARY}

Even though high waste loadings were achieved with the Acid-Bond 660 and XORB products neither product was able to retain the all of the RCRA characteristic metals in the SBW and NGLW simulants. In addition, the performance of Acid-Bond 660 was observed to degrade during the freeze/thaw and aging tests. For these reasons neither of the absorbents are recommended for treatment of the Tank Farm Wastes as a final waste form. However, XORB and Acid-Bond 660 in excess (at least $1 \mathrm{~g} / \mathrm{ml}$ of solution absorbed) could both be used to absorb Tank Farm Waste for shipment to a final treatment (i.e. vitrification). Acid-Bond 660 may require additional testing to ensure that the reaction with nitric acid has not produce an undesirable byproduct if vitrification or some other thermal process is selected as a final treatment.

\section{FISCAL YEAR 2001 PLANS}

During FY-2001, research efforts will be directed towards another Environmental Impact Statement alternative, namely, the direct vitrification of sodium-bearing waste. The Low-Activity Process Technology Program is being reprogrammed to resolve the issues of secondary waste from the vitrification process. Areas of needed research are grouting/disposal of the scrubber blowdown solution; disposal of activated carbon, HEPA filters, and ion exchange media; treatment/disposal of melter sulfate slag layer; and disposition of newly generated liquid waste after 2005. 


\section{REFERENCES}

1. Lockheed Martin Idaho Technologies Co., "High-Level Waste Program Plan," INEL-96/122, April 1996.

2. Bechtel BWXT Idaho, LLC, "Idaho Nuclear Technology and Engineering Center Newly Generated Liquid Waste Demonstration Project," INEEL/EXT-2000-00141, February 2000.

3. Bechtel BWXT Idaho, LLC, "Liquid Waste Treatment Pilot Plant and Demonstration Project Conceptual Design," to be released as INEEL/EXT-2000-0971.

4. A. K. Herbst, et al., "Idaho Nuclear Technology and Engineering Center Low-Activity Waste Process Technology Program FY-99 Status Report,” INEEL/EXT-99-00973, September 1999.

5. M. J. Dalton, "Rheology Measurements on Cement Grouts," AEEW-R 2094, Cementation Laboratory, Chemical Plant Development Group, AEE Winfrith, June 1986.

6. R. E. Schindler, Locheed Martin Idaho Technologies Co. Interdepartmental Communication to A. K. Herbst, "PEW Evaporator Bottoms," Schi-11-99, May 18, 1999.

7. Nardova, A. K. and Tumanova, O. S., "Examination of Mechanism of Saturation of Silica Gel with Metals at High Temperatures", Spectrum 1996 Proceedings.

8. Cicero-Herman, C.A. et al., "Silica Gel Treatment For Stabilization of Radioactive Materials", Westinghouse Savannah River Company Report WSRC-TR-97-0095, March 1997.

9. Maatman R. W. et al., "The Exchange of Twenty Metal Ions with the Weakly Acidic Silanol Group of Silica Gel," J. of Phys. Chem. 68 No 4 pp757 April 1964.

10. Meites L. et al., "Exchange of Na+ for the Silanolic Protons of Silica."J. inorg. nucl. 33, Oct 1971 pp.1293-1299.

11. Kirk-Othmer Encyclopedia of Chemical Technology, Third Edition, Volume 11, 1980, pp 826-829. 


\section{APPENDIX A}

ASME PEER REVIEW OF

LOW-ACTIVITY WASTE TREATMENT

AND

TANKS FOCUS AREA RESPONSE 



\title{
TECHNICAL PEER REVIEW REPORT
}

\author{
REPORT OF THE REVIEW PANEL
}

\section{LOW ACTIVITY WASTE FORMS}

\author{
Members of the Review Panel: \\ Edwin H. Abbott, Chair \\ Michael C. Kirkland \\ Samuel C. Morris \\ John M. Tuohy
}

AUGUST 8-10, 2000

IDAHO FALLS, ID

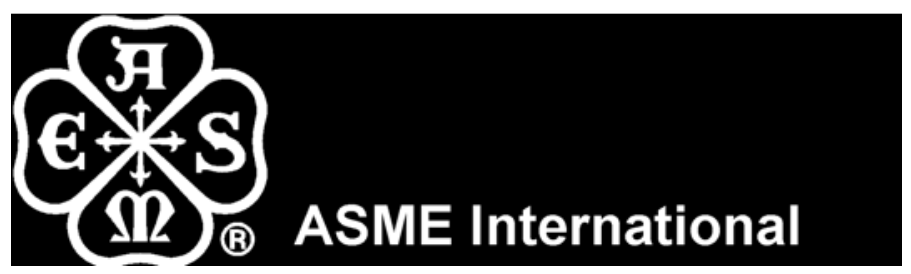

(Report Submitted: August 16, 2000) 


\section{INTRODUCTION}

Based on a request from the Office of Science and Technology (OST), Office of Environmental Management (EM), U.S. Department of Energy (DOE), a Review Panel (RP) was established to peer review the "Low Activity Waste Forms". The RP received reading materials provided by project

managers (1-10). The Project Summary and the Review Criteria were prepared by the Technical Secretary of the RP and approved by the DOE project managers. The RP met on August 8-10, 2000 in Idaho Falls, ID. At the beginning of the meeting, the RP was introduced to the American Society of Mechanical Engineers (ASME) peer review process and the DOE's desire for a non-conflicted and independent peer review. The Project Team presented its findings in about eight hours, and the RP had an executive session. On August 9, 2000, a discussion was held to give the RP the opportunity to ask clarifying questions. Subsequently, the RP prepared its Report of the Review Panel.

\section{PROJECT SUMMARY}

The objective of this project is to investigate the grouting of newly-generated liquid waste (NGLW) and sodium-bearing waste (SBW). NGLW is defined as liquid waste that is currently (or projected to be) produced at the Idaho Nuclear Technologies and Engineering Center (INTEC) as opposed to the SBW stored in the tank farm. Currently, all liquid wastes are evaporated and added to the tank farm. The tanks have been deemed non-compliant, and a cease use order must be met by the year 2012. The High-Level Waste Program Plan requires the tank waste to be separated via solvent extraction and ion exchange into high-activity and low-activity wastes (LAW). The LAW fraction is an acidic stream that may need conditioning before cementation to both improve the performance of the grout and to reduce the volume of the final waste form. The necessary pre-treatment and grouting processes included in this project are directed at treating mixed, transuranic, and low-level waste streams at INTEC.

The NGLW process involves diversion of the waste from the bottom of the Process Equipment Waste Evaporator (PEWE) to an existing 1,500-gallon vessel (WM-111). The waste would be placed in two waste tanks for further sampling and characterization. A line will be available to recycle the waste to the PEWE should the feed be rejected prior to grouting. If ion exchange is used, then the waste would be filtered and sent through cesium and strontium ion exchange resins. If the waste does not require separation, then it will be sent directly to the neutralization tank. For acid neutralization, it is proposed that the sodium hydroxide already be added in the neutralization vessel prior to the waste addition. The acidic waste will be slowly added to the base solution while stirring to keep the temperature under control. There is a 24-hour hold time to allow the solution reactions to reach equilibrium at a $\mathrm{pH}=12$ 12.5. This hold time is expected to allow aluminum hydroxide to form a crystalline structure rather than an amorphous precipitate; and therefore, it may help to produce a more stable grout waste form. The neutralized waste is transferred to the waste drums for in-drum mixing. During the mixing step, calcium hydroxide, portland cement, and blast furnace slag are added. The mixer blade may be left in the waste drum to avoid cleanup and contamination problems. The drums should set for $24 \mathrm{~h}$ to allow initial set of the grout. It is recommended that the drums cure for 28 days prior to shipment for disposal.

Another option includes continued boildown of the NGLW, so that it is essentially the same as SBW; therefore, the limited amount of added waste is relatively small compared to the total SBW, and only one process is needed.

The SBW process needs to include removal of the solids by solid-liquid separation; removal of the cesium through ion exchange or solvent extraction; and direct grouting. The project includes a cold demonstration in a Liquid Waste Treatment Pilot Plant prior to a hot demonstration using actual waste. 
Both wastes are Resource Conservation and Recovery Act (RCRA)-listed wastes with the F001, F002, F003, and U134 codes for organic compounds and hydrofluoric acid. The target waste disposal site must accept these listed codes. Presently, NGLW at low concentrations can go to Envirocare of Utah, while SBW is suitable for Waste Isolation Pilot Plant (WIPP) disposal.

AEA Technology in the United Kingdom (UK) is participating in this project as part of a DOE International Contract. The grouting technology planned for NGLW is being used in the UK; however, the grouting of SBW to meet the WIPP Waste Acceptance Criteria (WAC) is not used in the UK. For NGLW, the technology is readily-available and well-tested. The pre-treatment processes and grout formulations for SBW need testing to provide production facility design data.

\section{PEER REVIEW CRITERIA}

The RP was asked to assess the project based on the following review criteria:

Are the underlying bases for the individual steps as well as the integrated flowsheet for this project technically sound?

Are the design and execution of the project consistent with established scientific and engineering principles and standards?

Is the Project Team aware of relevant scientific and engineering publications as well as practices of the grouting industry?

Is the grout formulation technically sound?

Is the method of mixing waste and grout additives adequate?

Is the testing of the grouted waste forms sufficient and appropriate to meet the WAC of Envirocare and the WIPP?

Has the Project Team provided evidence indicating that this project meets an identified DOE Environmental Management need?

Do the results of these demonstrations have significant potential to provide the End User with the basis to 1) deploy the process; and 2) support the design and operation of a production facility?

Have occupational health and safety requirements been adequately addressed?

Have human health risks been adequately addressed?

Have ecological risks been adequately addressed?

Has the Project Team collected sufficient data to respond to regulatory (RCRA and DOE) and stakeholder concerns?

Do the demonstrations provide timely input to the design of the production facility (FY04)?

Is the project cost effective as demonstrated by life-cycle assessment?

Based on the technical merit of the project, is the likelihood of its deployment reasonably high?

Based on the overall assessment of the project, should it be continued?

\section{FINDINGS OF THE RP}

The findings of the RP with respect to the review criteria are as follows:

1. The underlying basis for each of the individual steps as well as the integrated flowsheet for the NGLW project (1) is technically sound. The process is based upon existing technologies that have been demonstrated and used in a production mode for this type of application.

2. The design and execution of the NGLW project are consistent with established scientific and engineering principles and standards. However, the information provided by the American National Standards Institute (ANSI)/ASME standards pertaining to low-level waste treatment at light-water reactors has not been fully utilized. 
3. The Project Team has taken into account current relevant scientific and engineering practices that are in use at other locations. In particular, incorporating the expertise of AEA Technology has been especially beneficial to the Project Team.

4. The grout formulation for the NGLW process is technically sound.

5. The method of mixing waste and grout additives for the NGLW is adequate.

6. The testing of the simulated grouted waste forms for the NGLW provides an appropriate level of confidence that the actual waste forms are likely to meet the WAC of Envirocare. The WIPP WAC do not pertain to the NGLW process. Currently, the SBW process does not meet the WIPP WAC.

7. The Project Team provided evidence that this project meets an identified DOE need.

8. The results of the NGLW demonstration have significant potential to provide the End User with the basis to 1) deploy the process; and 2) support the design and operation of a production facility.

9. The occupational health and safety requirements are being adequately addressed.

10. The human health risks are being adequately addressed.

11. The ecological risks are being adequately addressed.

12. The Project Team is collecting the data needed to respond to regulatory requirements (RCRA and DOE). However, stakeholders involvement and their input have not been addressed.

13. The demonstrations for the NGLW process provide timely input into the design of the production facility.

14. The Project Team has not performed a life-cycle assessment. The Project Team has provided data that indicate that the NGLW process is cost effective.

15. Based on the technical merit of the NGLW project, the likelihood of its deployment is reasonably high.

16. Based on the overall assessment, the NGLW project should be continued.

In addition, the RP has the following findings:

17. The SBW process is in an incipient stage. Based upon the information provided, the RP cannot assess the feasibility of modifying the NGLW treatment line to accommodate SBW treatment. However, serious regulatory and process development problems exist. The resolution of these problems is likely to impede the deployment of the SBW process.

18. Although a great amount of information was generated during this project, much of this information was documented in internal reports, memos, and related materials, rather than in publications in peerreviewed technical journals. The technological community in general, and the DOE in particular, would have benefited from dissemination of this information in peer-reviewed technical journals.

\section{RECOMMENDATIONS}

Based on a careful assessment of the information presented to the RP and the findings developed in response to the review criteria, the RP provides the following recommendations:

19. The Project Team should review for applicability the ANSI/ASME standards pertaining to low-level waste treatment at light-water reactors.

20. The Project Team should be proactive (beyond the Draft Environmental Impact Statement) in encouraging stakeholder participation, starting with the early stages of the project.

21. At the appropriate time, the Project Team should perform a life-cycle assessment.

22. During the life of the project, the Project Team should continue to address the occupational, health, and safety requirements; the human health risks; and the ecological risks. 
23. The Project Team is encouraged to seek regulatory relief to allow SBW disposal in WIPP.

24. The Project Team should publish the results of its findings in peer-reviewed scientific and technical journals.

\section{REFERENCES}

25. Idaho National Engineering and Environmental Laboratory. Idaho nuclear technology and engineering center newly generated liquid waste demonstration project feasibility study, INEEL/EXT-2000-00141. Idaho Falls, ID: Idaho National Engineering and Environmental Laboratory; (February) 2000.

26. Harbour, J. R. Meeting summary: Tank focus area review of the feasibility study for the grouting demonstration of newly generated liquid waste at Idaho, SRT-VTB-2000-013. Aiken, SC: Westinghouse Savannah River; June 22, 2000.

27. Herbst, A. K.; McCray, J. A.; Kirkham, R. J.; Pao, J.; Hinckley, S. H. Idaho nuclear technology and engineering center low-activity waste process technology program FY-99 Status Report, INEEL/EXT-99-00973. Idaho Falls, ID: Lockheed Martin Idaho Technologies; (September) 1999.

28. Pietrok, T. P. AEA INEEL Type 2 waste cementation gate review May 11-12, 1999. Richland, WA: Tanks Focus Area; July 19, 1999.

29. Holtzscheiter, E. W. Conditioning and immobilization of low-activity waste, TRN A9719. Aiken, SC: Westinghouse Savannah River; (June) 2000.

30. Musick, C. INEEL Immobilization. WT03 - TFA Tank waste pretreatment and immobilization, TTP ID77WT31. Task C: Conditioning and immobilization of low-activity waste to meet waste acceptance criteria. Idaho Falls, ID: Bechtel B\&W; December 12, 1999.

31. Herbst, A. INEEL Immobilization. TTP ID77WT31. Subtask D: Liquid waste treatment pilot and demonstration at Idaho. Idaho Falls, ID: Lockheed Martin Idaho Technologies; (June) 2000.

32. Johnson M. A.; Simmons, R. F.; Williams, J. R. A. Cementation of INEEL Type 2 waste, AEAT6095 Issue 1. Dorchester: AEA Technology; (September) 1999.

33. Harbour, J. R.; Herbst, A. Summary of the technology exchange on waste acceptance for Idaho LAW Forms (U), WSRC-RP-2000-00377. Aiken, SC: Westinghouse Savannah River; May 15, 2000.

34. Simmons, R. F.; Palethorpe, S. J.; Herbst, A. K.; Marshall, D. W. Solidification of acidic, highsodium low level waste at the Idaho National Engineering and Environmental Laboratory. Spectrum '98 International Conference on Decommissioning and Decontamination and on Nuclear and Hazardous Waste Management at Denver, CO, September 13-18, 1998. La Grange Park, IL: American Nuclear Society; 1998. 


\section{BIOGRAPHICAL SUMMARIES OF THE MEMBERS OF THE RP}

Edwin H. Abbott is currently Professor of Chemistry at Montana State University where he was Head of the department from 1977 until 1991. He also served as Director, Northern Rocky Mountain High Field Nuclear Magnetic Resonance Spectroscopy Facility. His professional experience includes his positions as Associate and Assistant Professor of Chemistry at Hunter College of the City University of New York; Chairman of the Inorganic Division of the City University of New York Doctoral Program in Chemistry; Postdoctoral Fellow at Texas A \& M University; and Visiting Scientist at the Massachusetts Institute of Technology and the National Science Foundation. From 1991 until 1997, Dr. Abbott was a Program Director for the National Science Foundation's Experimental Program to Stimulate Competitive Research. He is a member of the American Chemical Society, the New York Academy of Sciences, Sigma XI, Phi Lambda Upsilon, and the Council of Chemical Research. He is also Fellow of the New York Academy of Sciences. Dr. Abbott has participated on numerous panels for the National Science Foundation and U.S. Department of Energy. He has authored over 60 publications, and is past editor of the Journal of Coordination Chemistry. Edwin Abbott received a B.S. from Tufts University and a Ph.D. from Texas A \& M University.

Michael C. Kirkland is an independent consultant who led a team that performed a Congressionally-mandated External Independent Review of the \$ 1.3 billion Spallation Neutron Source Project at Oak Ridge. He assisted in the planning and review of a management assessment at a U. S. Department of Energy (DOE) Site that involved the restart of a plutonium facility. He participated in planning, procurement, and review activities in the environmental remediation area that included decommissioning activities at a shut down nuclear test reactor. During his tenure at Savannah River Site (SRS), Michael Kirkland was a Technical Advisor, Project Manager, and Director of the Project Engineering Division. He evaluated nuclear and mixed waste conditions and aspects of high level wastes and spent nuclear fuel; determined material inventories; performed pollution prevention and environmental health and safety evaluations for a proposed waste treatment facility; served as technical advisor to a study administered by the Savannah River Operations Office; and developed integrated schedules defined for this project. Michael Kirkland was director of the Project Engineering Division and managed the SRS design and construction program. He has been involved with waste management and environmental projects; cutting edge technology programs; and worked with lasers and magnetic containment. He served as Director of the Waste and Fuel Cycle Technology Office and planned and coordinated the programs of the DOE National High Level Waste Technology Office; the SR Fuel Cycle Technology Program; and the Commercial Interim Spent Fuel Management Program. He planned the initial construction of the Consolidated Incinerator Facility which thermally destroys excess benzene created by the In Tank Precipitation process that was to prepare feed material for the Defense Waste Processing Facility. Michael Kirkland was Director of the Commercial Nuclear Spent Fuel Storage Project Office and managed a contract between DOE and the Barnwell Commercial Nuclear Fuel Reprocessing Facility constructed by Allied General Nuclear Services. Michael Kirkland holds a B.S. in Mechanical Engineering from the University of South Carolina. He is registered as a Professional Engineer in South Carolina.

Samuel C. Morris is currently an independent consultant who has been involved in short-term consulting for Brookhaven National Laboratory, the World Health Organization; U.N. Environment Programme; National Commission on Air Quality; Power Authority of State of New York; U.S. Army Corps of Engineers; and Entek Research, Inc. He is also an Adjunct Associate Professor at the State University of New York at Stony Brook. He was formerly employed at the Brookhaven National Laboratory as Head of the Biological and Environmental Assessment Group and Deputy Head of the Energy Science and Technology Division. Previously, Samuel Morris worked as a Research Associate at the University of Pittsburgh's Graduate School of Public Health. He has been employed at the Illinois State University as an Assistant Professor of Environmental Health Science; with the U.S. Army as Chief of the 
Environmental Health Engineering Service and as Sanitary Engineer Mobilization Designee. His environmental restoration experience includes: 1) developing clean-up criteria for rad soils; 2)preparing analytical justification of regulatory approval of release of soil slightly contaminated with radionuclides to landfills not licensed as low-level waste facilities using RESRAD and TSD-Dose models, and 3) developing quantitative estimations of risk at U.S. Department of Energy (DOE) facilities nationwide for use in budget priorities. His risk analysis background consists of analyzing health effects of various national energy options for DOE. Samuel Morris is currently a member of the Editorial Board for Environmental Modeling and Assessment. Previously, he served on DOE's Beryllium Rule Advisory Committee and the Committee on Epidemiologic Investigations of Air Pollutants. He has worked on committee assignments such as the New York State Department of Environmental Conservation Comparative Risk Project; Human Health Work Group; and National Research Council Commission on Life Sciences. He is a member of the Society for Risk Analysis; American Society of Civil Engineers; The Institute for Operations Research and the Management Sciences; Delta Omega National Public Health Honor Society; and the Institute of Professional Environmental Practice. He has authored and coauthored over 100 publications including books; journal articles; chapters in books and proceedings; and reports. Samuel Morris holds a B.S. in Civil Engineering from the Virginia Military Institute; a M.S. in Sanitary Engineering from Rutgers University; and a Sc.D. in Environmental Health at the University of Pittsburgh's Graduate School of Public Health.

John M. Tuohy is Director of Nuclear Services at IDM Environmental where he is responsible for radiological decommissioning projects. Among them are decommissioning projects at Superfund and FUSRAP sites throughout the U.S., as well as projects at Oak Ridge, Los Alamos, and several other U.S. Department of Energy facilities. Previously, he was employed by Burns and Roe with responsibilities ranging from the design and procurement of waste treatment equipment to the recovery efforts at Three Mile Island. As Principal Nuclear Engineer, he evaluated safety issues for the Savannah River Production Reactors; designed radwaste systems for a modular high temperature gas-cooled production reactor; supervised a nuclear engineering group providing services to operating nuclear generating stations; and coordinated the design of a "state of the art" radioactive waste treatment facility for two twin light-water reactor sites. As Site Supervising Nuclear Engineer, he managed an engineering group that engineered, procured, constructed, and started up systems needed for the recovery effort at Three Mile Island. Prior to that, he taught graduate courses in Nuclear Engineering at Stevens Institute of Technology, and was a licensed Senior Reactor Operator for the Manhattan College Zero Power Reactor. John Tuohy is a member of the American Nuclear Society and American Society of Mechanical Engineers (ASME). He is past Chairman of the ASME Radwaste Systems Committee and is currently a member of the ASME Nuclear Engineering Division Executive Committee. He is author or coauthor of several publications. He received a Bachelor of Mechanical Engineering from Manhattan College, New York, and a M.S. in Nuclear Engineering from Massachusetts Institute of Technology. John Tuohy is a Registered Professional Engineer in New Jersey, New York, and Pennsylvania. 


\section{Tanks Focus Area Response to the ASME Technical Peer Review Report Recommendations on Low Activity Waste Forms ${ }^{1}$}

\section{The Project Team should review for applicability the ANSI/ASME standards pertaining to low-level waste treatment at light-water reactors.}

DOE Response: The Tanks Focus Area believes the project team has adequately addressed questions of standards and waste acceptance criteria as discussed below and therefore has already fulfilled the intent of this recommendation. In general, commercial nuclear power facilities generate low-level waste (LLW) rather than mixed waste (mixed LLW). Therefore, disposal of the immobilized commercial waste is directed at disposal facilities that accept LLW and their waste forms must comply with the waste acceptance criteria for these facilities. Idaho's newly generated liquid waste (NGLW) and sodium-bearing waste (SBW) are both mixed LLW and their disposal requirements are therefore different. The approach proposed by the project team is to produce a grouted waste form for NGLW that complies with the waste acceptance criteria for Envirocare of Utah, Inc., a facility that accepts mixed $\mathrm{LLW}^{2}$. The waste acceptance criteria of this and other mixed LLW disposal sites were thoroughly evaluated by the project team prior to selecting Envirocare as the preferred disposal site. In early FY00, TFA sponsored a workshop with grouting experts from across the DOE complex to review the proposed treatment process for NGLW. ${ }^{3}$ The team of experts that participated in this workshop is well versed in the standards and waste acceptance criteria used for disposal of both LLW and mixed LLW. Their review of the proposed treatment and disposal for NGLW provided an assessment of its appropriateness in terms of applicable standards and the ability to meet waste acceptance requirements for the proposed waste disposal site (Envirocare). The workshop participants agreed with the selection of Envirocare and the approach being used by the project team to develop and demonstrate a waste form product that would meet the waste acceptance criteria. Also, by partnering with AEA Technologies (AEAT), a company that is internationally recognized for their grouting expertise and deployment of successful LLW and mixed LLW treatment processes, the project team gained and utilized AEAT's international experience in the grouting of LLW streams.

2. The Project Team should be proactive (beyond the Draft Environmental Impact Statement) in encouraging stakeholder participation, starting with the early stages of the project.

DOE Response: The Focus Area agrees in principle with this recommendation. However, the Tanks Focus Area has established a working agreement with the participating DOE Tank Sites (users) that stakeholder interactions are the responsibility of the DOE operations offices

\footnotetext{
${ }^{1}$ ASME/CRTD-RP-00-14

${ }^{2}$ See Feasibility Study Section 2.3; ASME Report Reference 1.

${ }^{3}$ Results of the meeting are summarized in WSRC-RP-2000-00377, Harbour and Herbst, "Summary of the Technology Exchange on Waste Acceptance for Idaho LAW forms".
} 
and contracting organizations at those sites. Therefore, stakeholder involvement in the project would be at the discretion of DOE-ID and their site contractors, not the TFA performers. As indicated in the recommendation, the process of stakeholder involvement had already begun in a general sense with the issuance of the Draft Environmental Impact Statement (EIS). Grouting of NGLW was identified in several of the EIS alternatives presented for comment. The Idaho Site also has a formal protocol for ensuring that all affected stakeholders are involved. The process has been initiated for this project and preliminary discussions with the State of Idaho on treatment of the NGLW and permitting strategies have already been started. The first phase of this project is a demonstration project using a pilot plant facility to prove the feasibility of the grouting process for immobilization of Newly Generated Liquid Waste. This pilot plant facility will use only simulated waste materials. Stakeholders will be involved in participating in this demonstration as the project proceeds. The radioactive demonstration is currently scheduled for 2003 . We agree that now is the time to begin the process of stakeholder participation in expectation that this option has a high probability of being implemented. The TFA is confident that DOE-ID and INEEL will do so as the site finalizes the EIS and Record of Decision on treatment of liquid waste and initiates the pilot demonstration for NGLW treatment.

3. At the appropriate time, the Project Team should perform a life-cycle assessment. DOE Response: The Focus Area concurs with this recommendation. DOE requires that a Life Cycle Cost Estimate be performed as part of the design effort. Idaho normally provides the full life cycle cost estimates at the time of completion of Title design. As part of the design efforts for grouting of the NGLW, individual tasks within the project have been and are being analyzed to ensure that cost effectiveness is addressed and realized. Idaho will use these individual cost estimates and data generated in the pilot unit as input to the final integrated life cycle cost analysis. This formal life cycle assessment will be issued after completion of the Title design. Initial cost estimates were developed and documented in the feasibility study (INEEL/EXT-2000-00141) ${ }^{4}$ provided to the review team. This information was presented to DOE-ID as part of the package used to obtain approval to proceed with conceptual design of the NGLW grout process, which was authorized in February 2000.

\section{During the life of the project, the Project Team should continue to address the occupational, health, and safety requirements; the human health risks; and the ecological risks.}

DOE Response: The Focus Area concurs with this recommendation. These considerations are extremely important and of highest priority to the project team. The project has demonstrated an early attention to these matters as evidenced by the active involvement of representatives of the site's environmental, safety, and health organizations in project planning and reviews. Representatives of these organizations have participated in several project reviews that TFA has attended. The feasibility study (INEEL/EXT-2000-00141) addresses safety and ALARA, safety analysis report implications, and Environmental Permitting. Human health and safety is addressed through the Integrated Safety Management System, implementation of the Work Control Procedure STD-101, and adherence to the

\footnotetext{
${ }^{4}$ This study is listed in Reference 1 of the ASME report.
} 
Occupational Safety and Health Act. The ecological risks are addressed by an environmental evaluation that includes compliance with NEPA, RCRA, NESHAPS, CAA, and CWA requirements, plans that prevent storm water pollution, a review of potential historical and cultural impacts, and following a strategy of waste minimization and appropriate waste disposal. This focus on human health and safety and the environment will continue to be maintained as a high priority throughout the entire project.

\section{The Project Team is encouraged to seek regulatory relief to allow SBW disposal in WIPP.}

DOE Response: The Focus Area agrees in principle with this recommendation. It is most important to determine whether the SBW is HLW (and consequently destined to be disposed of in a Federal Repository) or mixed LLW that can be treated, immobilized and sent to existing waste disposal facilities (e.g., WIPP and The Nevada Test Site). It is important to recognize that the decision to seek resolution of the classification of SBW is the responsibility of DOE-ID and is not within the scope of the Focus Area's project responsibilities. However, the TFA has recently assisted DOE-ID in conducting an independent review of their EIS alternatives and a similar recommendation was contained in the report of that review5. DOE-ID is currently in the process of pursuing a "waste incidental to reprocessing" determination for the SBW that will accomplish this. A timely decision on whether SBW is HLW would greatly facilitate planning for, and execution of, the disposition of this waste stream.

6. The Project Team should publish the results of its findings in peer-reviewed scientific and technical journals.

DOE Response: The Focus Area agrees in principle with this recommendation. However, the funding for publishing the results in peer-reviewed scientific and technical journals has not been a priority for the Idaho site user and was not specifically provided by TFA for this project. The TFA is currently evaluating, in general, the need for increasing the publication of results of program investments. TFA intends to develop a general strategy to address this issue, which focuses on a graded approach that evaluates the need for publication in peer reviewed journals for its projects based on the stage of development, need for communicating the results to the broader user and technical community, and the need and appropriate methodology for technical review of the project. In the case of this project specifically, TFA believes the results of the AEAT testing, grout formulation, and process development work is worthy of publication and may benefit other sites and projects. In FY01, TFA will encourage AEAT to publish this work in an appropriate technical journal.

\footnotetext{
${ }^{5}$ PNNL 13268 “Assessment of Selected Technologies for the Treatment of Idaho Tank Waste and Calcine” August 2000.
} 


\section{APPENDIX B}

HEAT OF NEUTRALIZATION CALCULATIONS 



\section{INTEROFFICE MEMORANDUM}

Date: $\quad$ September 21, 2000

To:

J. A. McCray

MS 5218

$6-3745$

From:

L. Lauerhass

MS 5218

6-5018

Subject: $\quad$ TEMPERATURE RISE FROM NEUTRALIZATION OF SIMULATED SBW

References: (a) The NBS tables of chemical thermodynamic properties, Journal of Physical and Chemical Reference Data, Vol. 11, 1982 Supplement No. 2

(b) Handbook of Chemistry and Physics, 48th Edition, 1967-1968, p B-163.

(c) International Critical Tables, Vol. 5, 1929

\section{Summary}

The temperature rise due to neutralization of simulated Sodium Bearing Waste (SBW) was estimated as requested by the Grout Development group at INTEC for the following two cases:

- Neutralization using $11 \mathrm{~g}$ of $\mathrm{CaO}$ per $70 \mathrm{~g}$ of SBW solution [90\% excess $\mathrm{CaO}$ ]

- Neutralization using $14 \mathrm{~g}$ of $\mathrm{Ca}(\mathrm{OH})_{2}$ per $70 \mathrm{~g}$ of SBW solution $\left[83 \%\right.$ excess $\left.\mathrm{Ca}(\mathrm{OH})_{2}\right]$

The predicted temperature rise is $92^{\circ} \mathrm{C}$ for neutralization using $\mathrm{CaO}$ and $38^{\circ} \mathrm{C}$ for neutralization using $\mathrm{Ca}(\mathrm{OH})_{2}$. The temperature rise predicted for $\mathrm{CaO}$ neutralization might not be fully realized in laboratory tests since the boiling point of the solution would probably be exceeded.

The significant excess of $\mathrm{CaO}$ and $\mathrm{Ca}(\mathrm{OH})_{2}$ in the grout recipes is necessary to avoid free liquids for grout formulations with the high waste loadings $(70 \mathrm{wt} \%)$ being investigated.

\section{SBW Composition and Thermochemical Data}

The relevant composition data of the simulated SBW used in the calculations were:

$$
\begin{array}{ll}
{\left[\mathrm{HNO}_{3}\right]=} & 1.9600 \mathrm{M} \\
{\left[\mathrm{Al}\left(\mathrm{NO}_{3}\right)_{3}\right]=} & 0.6030 \mathrm{M} \\
{\left[\mathrm{Fe}\left(\mathrm{NO}_{3}\right)_{3}\right]=} & 0.0222 \mathrm{M} \\
{\left[\mathrm{NO}_{3}^{-}\right]=} & 5.64 \mathrm{M} \\
\text { Density }= & 1.3 \mathrm{~g} / \mathrm{cc}
\end{array}
$$


J. A. McCray

September 21, 2000

LL-01-00

Page 2

The following heat of formation data was used to calculate heats of reaction (Reference a):
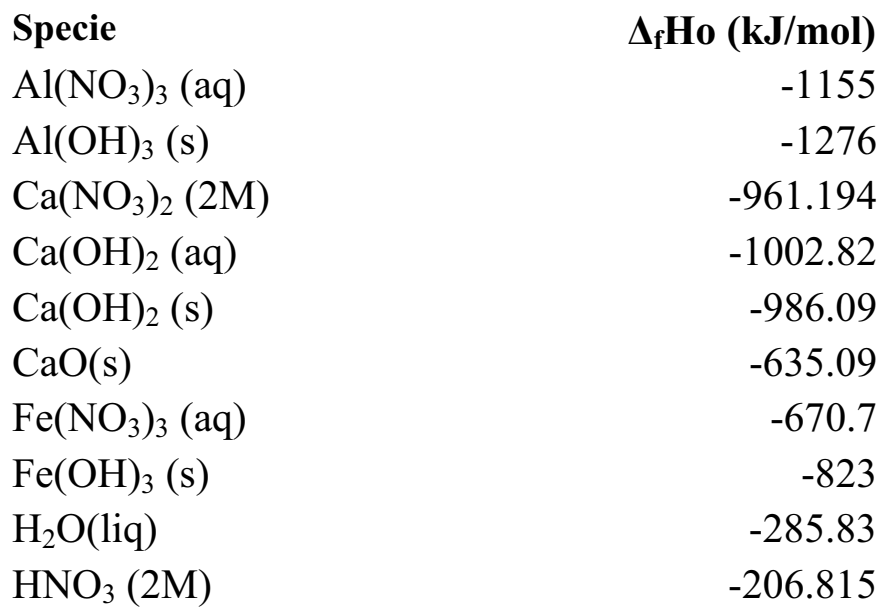

\section{$\mathrm{CaO}$ Neutralization}

Based on the addition of $11 \mathrm{~g}$ of $\mathrm{CaO}$ to $70 \mathrm{~g}$ of SBW solution, a temperature rise of $92^{\circ} \mathrm{C}$ is predicted as shown in Table 1 . There is $90 \%$ excess $\mathrm{CaO}$ beyond that required to react with nitric acid and precipitate aluminum and iron in solution. Approximately $25 \%$ of the temperature rise is due to heat evolved from the hydration of the $90 \%$ excess $\mathrm{CaO}$ to solid $\mathrm{Ca}(\mathrm{OH})_{2}$.

\section{$\mathrm{Ca}(\mathrm{OH})_{2}$ Neutralization}

Based on the addition of $14 \mathrm{~g}$ of $\mathrm{Ca}(\mathrm{OH})_{2}$ to $70 \mathrm{~g}$ of SBW solution, a temperature rise of $38^{\circ} \mathrm{C}$ is predicted as shown in Table 2. There is $83 \%$ excess $\mathrm{Ca}(\mathrm{OH})_{2}$ beyond that required to react with nitric acid and precipitate aluminum and iron in solution. The $83 \%$ excess $\mathrm{Ca}(\mathrm{OH})_{2}$ is essentially insoluble and remains as unreacted solid.

Sm

cc: $\quad$ A. K. Herbst, MS 5218

D. A. Jolly, MS 5106

D. M. Meyer, MS 5106

C. A. Musick, MS 5218

J. A. Rindfleisch, MS 5218

D. D. Taylor, MS 3625

R. J. Waters, MS 5227

L. Lauerhass (LL-01-00) 
J. A. McCray

September 21, 2000

LL-01-00

Page 3

\section{Table 1. Calculation for Neutralization with $\mathrm{CaO}$}

Simulated SBW composition:

\begin{tabular}{l|l} 
[HNO3] & $1.9600 \mathrm{M}$
\end{tabular}

$\left[\mathrm{Al}\left(\mathrm{NO}_{3}\right)_{3}\right] \quad 0.6030 \mathrm{M}$

$\left[\mathrm{Fe}\left(\mathrm{NO}_{3}\right)_{3}\right] \quad 0.0222 \mathrm{M}$

$\left[\mathrm{NO}_{3}{ }^{-}\right] \quad 5.64 \mathrm{M}$

Density $1.3 \mathrm{~g} / \mathrm{cc}$

Reaction (1) $\mathrm{CaO}(\mathrm{s})+2 \mathrm{HNO}_{3}(2 \mathrm{M})==>\mathrm{Ca}\left(\mathrm{NO}_{3}\right)_{2}(2 \mathrm{M})+\mathrm{H}_{2} \mathrm{O}$ (liq)

$\Delta \mathbf{H}_{\mathrm{rxn}}$

$-198.3 \mathrm{~kJ}$

(2) $3 \mathrm{CaO}(\mathrm{s})+2 \mathrm{Al}\left(\mathrm{NO}_{3}\right)_{3}(\mathrm{aq})+3 \mathrm{H}_{2} \mathrm{O}$ (liq) $==>3 \mathrm{Ca}\left(\mathrm{NO}_{3}\right)_{2}(2 \mathrm{M})+2 \mathrm{Al}(\mathrm{OH})_{3}(\mathrm{~s})-362.8 \mathrm{~kJ}$

(3) $3 \mathrm{CaO}(\mathrm{s})+2 \mathrm{Fe}\left(\mathrm{NO}_{3}\right)_{3}(\mathrm{aq})+3 \mathrm{H}_{2} \mathrm{O}$ (liq) $==>3 \mathrm{Ca}\left(\mathrm{NO}_{3}\right)_{2}(2 \mathrm{M})+2 \mathrm{Fe}(\mathrm{OH})_{3}$

(4) $\mathrm{CaO}(\mathrm{s})+\mathrm{H} 2 \mathrm{O}$ (liq) $==>\mathrm{Ca}(\mathrm{OH})_{2}(\mathrm{~s})$

(5) $\mathrm{Ca}(\mathrm{OH})_{2}(\mathrm{~s})==>\mathrm{Ca}(\mathrm{OH})_{2}(\mathrm{aq})$

Amount of $\mathrm{CaO}(\mathrm{s})$ added during neutralization $=11 \mathrm{~g}$ per $70 \mathrm{~g}$ SBW

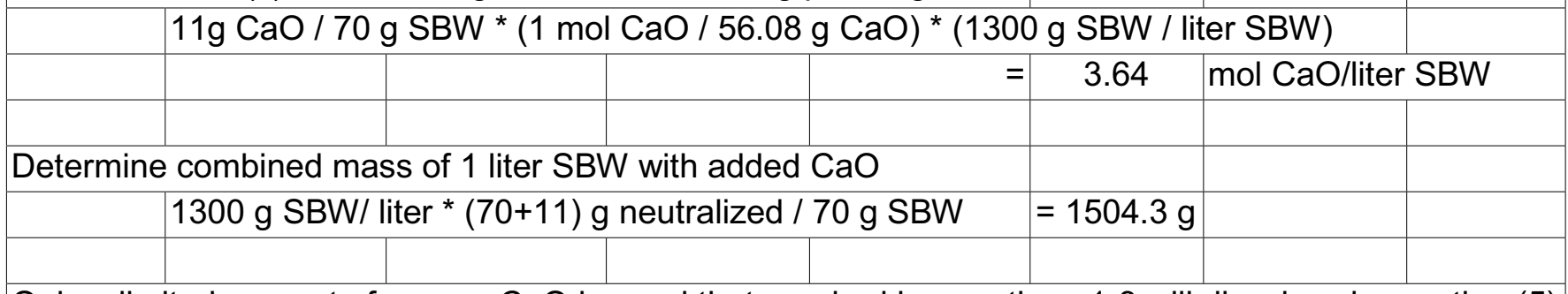

Only a limited amount of excess $\mathrm{CaO}$ beyond that required by reactions 1-3 will dissolve via reaction (5)

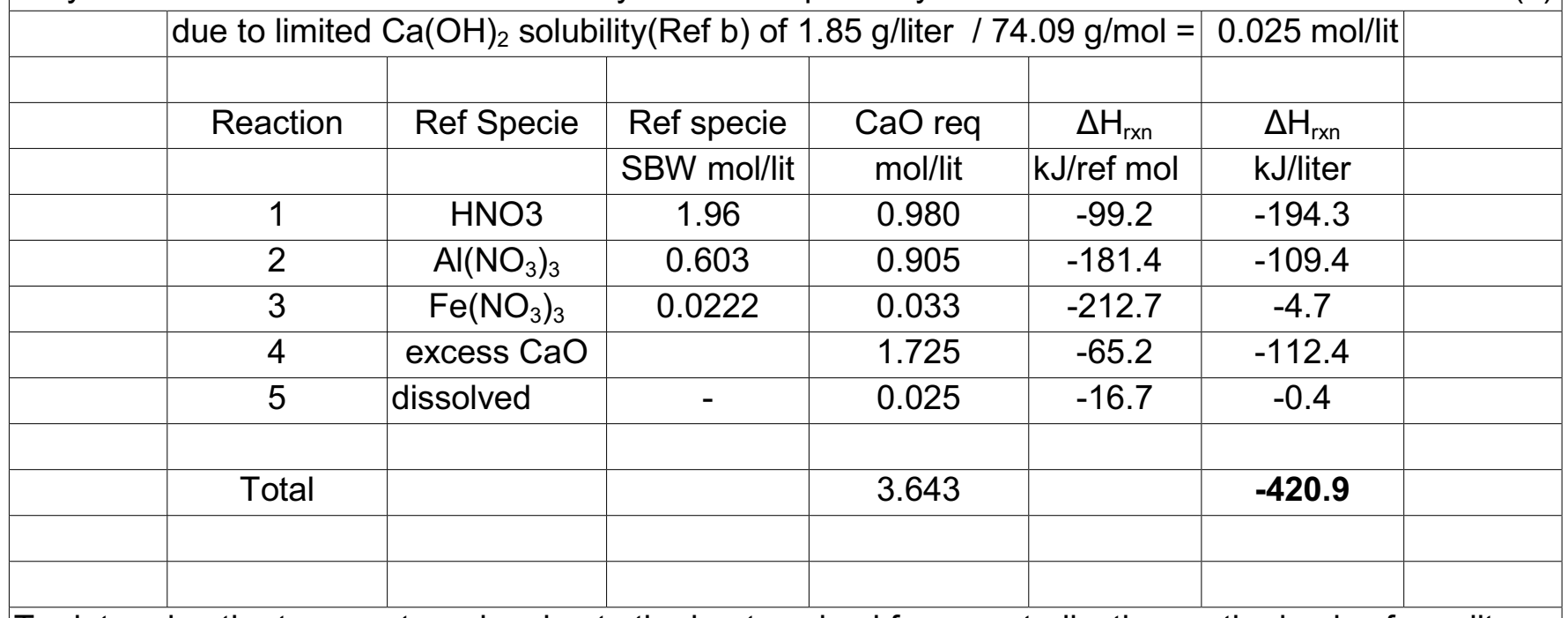

To determine the temperature rise due to the heat evolved from neutralization on the basis of one liter: 
J. A. McCray

September 21, 2000

LL-01-00

Page 4

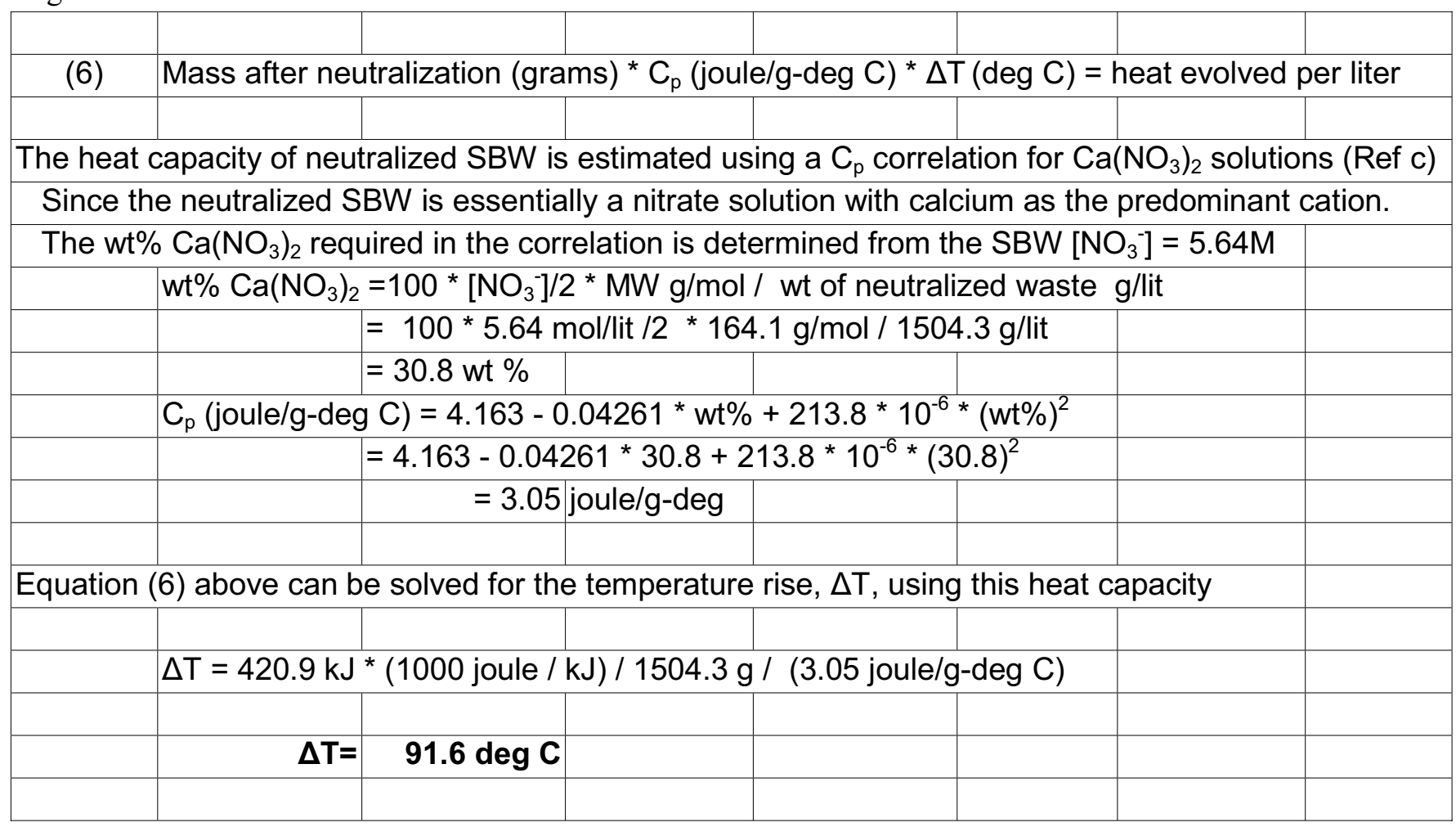


J. A. McCray

September 21, 2000

LL-01-00

Page 5

Table 2. Calculation for Neutralization with $\mathrm{Ca}(\mathrm{OH})_{2}$

Simulated SBW composition(only key components for

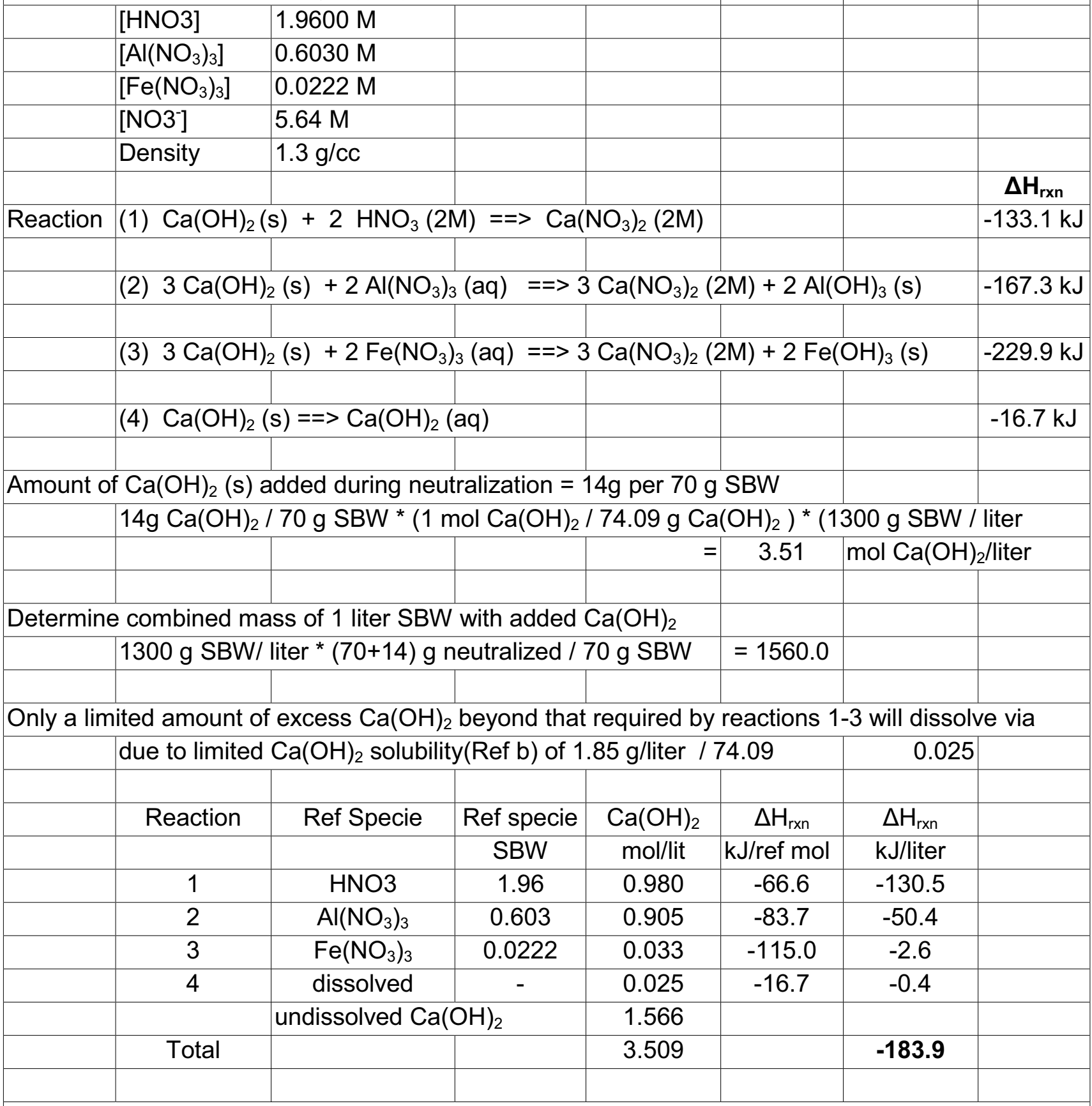

To determine the temperature rise due to the heat evolved from neutralization using a 1 liter SBW

(5) Mass after neutralization (grams) ${ }^{*} C_{p}$ (joule/g-deg $\left.C\right) * \Delta T($ deg $C)=$ heat evolved per liter 
J. A. McCray

September 21, 2000

LL-01-00

Page 6

The heat capacity of neutralized SBW is estimated using a $\mathrm{C}_{\mathrm{p}}$ correlation for $\mathrm{Ca}\left(\mathrm{NO}_{3}\right)_{2}$ solutions

Since the neutralized SBW is essentially a nitrate solution with calcium as the predominant cation.

The $\mathrm{wt} \% \mathrm{Ca}\left(\mathrm{NO}_{3}\right)_{2}$ required in the correlation is determined from the SBW $\left[\mathrm{NO}_{3}{ }^{-}\right]=$

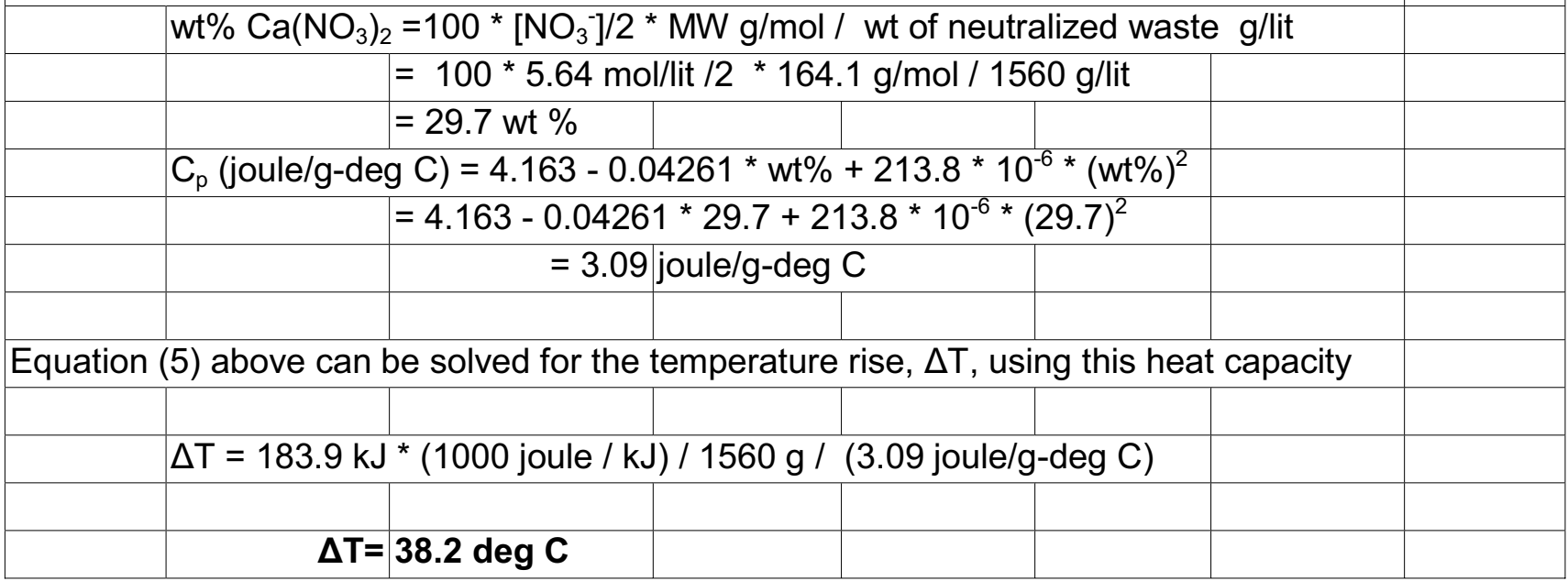




\section{APPENDIX C}

CPP-604 GROUT TREATMENT OF NGLW 



\title{
WHITE PAPER
}

\section{CPP-604 GROUT TREATMENT OF NEWLY GENERATED LIQUID WASTE}

\author{
(C. L. Bendixsen - 9/19/00)
}

\begin{abstract}
ISSUE: Can CPP-604 be recommended as a treatment facility for routine conversion of newly generated liquid waste (NGLW) to a grout form to be packaged and shipped to Envirocare of Utah?
\end{abstract}

BACKGROUND: As agreed upon with the Department of Energy-Idaho Office (DOE-ID) all newly generated liquid waste (NGLW) going to unpermitted high level waste tanks shall be eliminated no later than 2005. The NGLW comprises rad-waste liquid streams from the Idaho Nuclear Technology and Engineering Center (INTEC), including streams from fuel storage basins, storm water runoff, evaporation and off-gas cleanup operations, analytical laboratories, New Waste Calcining Facility (NWCF) decon shop, and other Idaho National Engineering and Environmental Laboratory (INEEL) locations. (A listing of sources and estimated volumes may be found in Reference 1.) Such liquid waste streams will be concentrated in a permitted Process Equipment Waste Evaporating (PEWE) system. Alternatives for storage and treatment of the PEWE concentrates include:

1. interim storage in RCRA permitted tanks (WM-100, -101, -102) or in new underground storage tanks,

2. conversion to grout either in a proposed sodium-bearing waste (SBW) treatment facility or in CPP604 Liquid Waste Treatment (LWT) facility, (to be discussed herein), and

3. interim storage in new tank farm vessels followed by conversion to solids in a calcine treatment facility.

In the LWT process, NGLW would be converted to a grout contained in 55-gal drums, acceptable for shipment to Envirocare of Utah. Since rad-waste grouting is likely to be used in several of the process pathways, 'hot' pilot plant testing of the grout process is being strongly encouraged, with the 'hot' pilot plant proposed for CPP-604 installation. This white paper summarizes some issues related to conversion of the "hot" pilot plant to a routine operating waste treatment facility.

PROCESS DESCRIPTION: As presently conceived, a Liquid Waste Treatment (LWT) process would be installed in the Middle Cell of Building CPP-604. Major process functions or steps would include: NGLW hold tank, acid neutralization (or reaction) tank, batch tank, in-drum grout mixing, followed by waste drum capping, handling, and load out. For this assessment, neither Cs nor Sr removal was considered to be part of the process. (A more complete description of the NGLW treatment process and equipment is contained in Reference 2)

The NGLW, after evaporative concentration in the PEWE process, would be transferred to a new, but presently unpermitted, vessel WM-111 (1500 gal volume) for holding until the LWT is operated. Periodically, NGLW would be transferred to smaller feed tanks atop the LWT facility. Solution from the feed tank would be gravity fed to a neutralization tank for reaction of excess nitric acid with sodium hydroxide, raising the $\mathrm{pH}$ value to approximately 12 . The neutralized NGLW would be transferred to a batch tank, and thence to a 55-gal drum. Grout additives consisting of calcium hydroxide, granulated blast furnace slag, and portland cement would be added, and mixed inside the drum to form a 
"performance" grout. After curing, the "performance" grout would be self supporting and capable of passing EPA leach tests. After storage for approximately 24 hours (minimum curing period), the grout drum would be capped, transferred to appropriate shipping containers, and shipped for disposal at Envirocare of Utah. No significant storage of grouted NGLW is contemplated.

DISCUSSION OF ISSUES: A positive decision for grouting of NGLW in a CPP-604 Liquid Waste Treatment (LWT) process would require resolution of several issues, including predicted NGLW volumes, PEWE boildown ratios, facility operating capacity, Envirocare waste acceptance criteria (WAC), remote operability, schedule, and costs.

With one critical exception, a resolution of each issue appears positive, although further investigation of some is required/recommended. The single, and critical, exception is that the PEWE concentrate will contain estimated fission product concentrations far in excess of limits established by Envirocare of Utah.

NGLW Volumes and Boildown: Obviously, the predicted volume of NGLW from 2005 onward is important to evaluating interim storage needs and treatment facility requirements. A liquid waste management plan (Reference 1) estimated that after boildown of NGLW streams in the PEWE system, that less than 9,000 gal/year of concentrated waste would result. [Note: A draft update of Reference 1, liquid waste management plan, indicates that the NGLW volume will be less than 7,000 gal/yr. (Reference 6)] This is based on five important assumptions:

- Further evaporation and concentration of liquid wastes in the CPP Tank Farm in the HighLevel Liquid-Waste Evaporator would be completed by mid-2003

- Processing of CPP-603 basin water through the PEWE would be completed before 2005 (Reference 6 suggests that this assumption should be reassessed.

- Necessary decontamination of the NWCF would be completed before 2005

- Shutdown and decontamination of other INEEL important facilities also would be completed before 2005

- PEWE boildown (feed to concentrate) ratio would be approximately 1000:1, with the ratio determined by maximum solubility of dissolved metal salts and chloride concentration.

Completion of these tasks would greatly reduce the anticipated low-level radioactive liquid waste volumes which would be a part of NGLW from 2005 forward. Only many smaller, and easily concentrated, volumes then would be processed in the PEWE system. With the high boildown ratio, it was estimated that during the period 2005-2010, that a total of 52,000 gallons of concentrated NGLW would result (Reference 1), and could be interimly stored in existing RCRA permitted tanks (WM-100, 101, -102). Management of NGLW during the 2005-2010 period assumes that a treatment facility for sodium bearing waste would be operable in 2010 , and could also process the NGLW concentrate. NGLW concentrate volumes after 2012 have been estimated to be less than 15,000 gal/yr. (Reference 6), but may vary from 7,000 to 10 times more gal/yr., depending on tank flushings and facility closeouts. (Reference 7)

Processing Rates and Envirocare WAC: The importance of LWT processing capacity is interdependent with NGLW volumes and with a grout formulation needed to meet the Envirocare Waste Acceptance Criteria (WAC). Important limits in the Envirocare WAC (relative to INTEC NGLW) include cesium, strontium, and mercury. Based on some evaluations, PEWE boildown ratios might be limited to about $31: 1$, when assuming that HLLWE overheads and CPP-603 basin water would be part of NGLW from 2005 onward. However, based on present operating schedules, these waste streams will have been addressed prior to 2005. It appears that after 2004 important sources of strontium, cesium, and perhaps mercury will be primarily from HEPA filter leaching and other routine equipment decontamination in the NWCF Decon Facility. Other NGLW sources within INTEC and from the INEEL should contain many 
fewer fission product isotopes. Estimating components of the NGLW concentrate is a difficult task. Although the total dissolved salts composition may be assumed to be similar to that occurring in the past (Reference 8), the fission product isotopes content is speculative as it is based on very few analyses of NWCF Decon Facility solutions (Reference 9). However the analytical data do indicate fission product values similar to existing SBW, which far exceeds (20x to 600x) limits established by Envirocare of Utah.

The proposed LWT facility does appear to have considerable range of flexibility. Early conceptual design studies indicate that the LWT could have a drum production rate of 10-drums/10-hr shift, or about 24 drums per 24-hr. day. The needed drum production rate is directly proportional to the ratio of NGLW concentrate to final grout product (expressed either as a weight or volume fraction). The allowable waste fraction (weight or volume) is a direct function of NGLW cesium and/or strontium concentration and Envirocare WAC for these same components. It is assumed that appropriate mixing of the NGLW with varying grout additives will provide a final grout composition, which meets the Envirocare WAC limits. For purposes herein, a tabular range of assumed waste:grout volume fractions would result in the following annual drum production and associated LWT operating periods. The annual NGLW volume is assumed to be $10,000 \mathrm{gal} / \mathrm{yr}$.

\section{Estimated Drum Production Rates and Facility Operating Days}

\begin{tabular}{|c|c|c|c|c|}
\hline $\begin{array}{c}\text { NGLW Volume, } \\
\text { Concentrate } \\
(1000: 1), \text { gal } / \mathrm{yr} .\end{array}$ & $\begin{array}{l}\text { Waste Loading Vol. } \\
\text { Fraction, } \\
\mathrm{m}^{3} \text { waste } / \mathrm{m}^{3} \text { grout }\end{array}$ & $\begin{array}{l}\text { Annual Drum } \\
\text { Production, } \\
\text { 50-gal drums }\end{array}$ & $\begin{array}{l}\text { LWT Operation, } \\
\text { days at } 10 \\
\text { drums/day }\end{array}$ & $\begin{array}{c}\text { LWT } \\
\text { Operation, } \\
\text { days at } 24 \\
\text { drums/day }\end{array}$ \\
\hline$<10,000$ & 0.005 & 40,000 & 4000 & 1660 \\
\hline$<10,000$ & 0.01 & 20,000 & 2000 & 830 \\
\hline$<10,000$ & 0.02 & 10,000 & 1000 & 415 \\
\hline$<10,000$ & 0.05 & 4,000 & 400 & 167 \\
\hline$<10,000$ & $0.10 *$ & 2,000 & 200 & 83 \\
\hline$<10,000$ & 0.20 & 1000 & 100 & 42 \\
\hline$<10,000$ & 0.40 & 500 & 50 & 21 \\
\hline$<10,000$ & 0.60 & 333 & 33 & 14 \\
\hline \multicolumn{3}{|c|}{$\begin{array}{c}\text { *Bolded values are considered reasonable volume and } \\
\text { system operating ranges }\end{array}$} & & \\
\hline
\end{tabular}

As stated previously, the concentrations of cesium and strontium in the NGLW concentrate (i.e., PEWE bottoms) can only be estimated at this time. However, the reported radionuclide concentrations strongly suggest that grout performance loadings must be $1 \%$ or less in order to meet the Envirocare limits.

Schedule and Costs: Not evaluated since Envirocare limits would be so difficult to meet.

CONCLUSIONS AND RECOMMENDATIONS: Conclusions and recommendations are as follows:

- The success potential for a 'hot' NGLW Liquid Waste Treatment facility in the Middle Cell of CPP-604 is not favorable, due to inability to meet the radionuclide limits for Envirocare of Utah.

- A NGLW Liquid Waste Treatment facility in CPP-604 is considered highly technically viable and has low technical risk, simple processes, demonstrated nuclear technology, process flexibility. 
- Should grouting be a part of NGLW or SBW treatment, it is highly recommended that an orderly development and testing schedule be followed, from 'cold' pilot plant tests in CPP-1634 to 'hot' pilot plant tests in CPP-604.

- Better estimates of NGLW composition (chemical and radioactive isotopes) in 2005 and beyond are recommended, and perhaps need to be obtained through additional sampling and analyses of PEW solutions from the NWCF Decon Facility.

- Design issues for grout formulation control, equipment design, and drum handling will be resolved during 'cold' and 'hot' testing, providing confidence that a grouting facility would perform as intended.

\section{REFERENCES:}

1. PLAN - INEEL Liquid Waste Management, PLN-439, Rev. 4, (October 6, 1999)

2. INTEC Newly Generated Liquid Waste Demonstration Project Feasibility Study, INEEL/EXT-200000141 (February 2000)

3. ICPP Low-Activity Waste Grout Stabilization Development Program, FY-97 Status Report, INEEL/EXT-98-00116 (February 1998)

4. Personal communication, Alan K. Herbst, September 11, 2000

5. Personal communication, Robert J. Waters, September 11,2000

6. INTEC Waste Management Through 2070, INEEL/EXT-2000-01005, September 2000 (DRAFT)

7. Personal communication, Clark Millett, September 12, 2000

8. J. A. McCray letter to A. K. Herbst "TYPE 2 WASTE DISPOSAL," JAM-03-98, dated August 11, 1998

9. J. A. McCray letter to A. K. Herbst "TYPE 2 WASTE SIMULANT COMPOSITION," JAM-04-98, dated August 26, 1998 